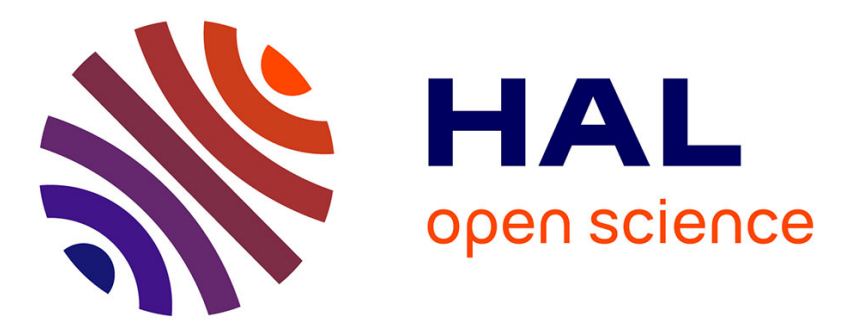

\title{
The coupling of CO2 with diols promoted by organic dual systems: Towards products divergence via benchmarking of the performance metrics
}

\author{
A. Brege, R. Méreau, K. Mcgehee, B. Grignard, C. Detrembleur, C. Jerome, \\ T. Tassaing
}

\section{To cite this version:}

A. Brege, R. Méreau, K. Mcgehee, B. Grignard, C. Detrembleur, et al.. The coupling of CO2 with diols promoted by organic dual systems: Towards products divergence via benchmarking of the performance metrics. Journal of CO2 Utilization, 2020, 38, pp.88-98. 10.1016/j.jcou.2020.01.003 . hal-02990835

\section{HAL Id: hal-02990835 \\ https://hal.science/hal-02990835}

Submitted on 10 Nov 2020

HAL is a multi-disciplinary open access archive for the deposit and dissemination of scientific research documents, whether they are published or not. The documents may come from teaching and research institutions in France or abroad, or from public or private research centers.
L'archive ouverte pluridisciplinaire $\mathbf{H A L}$, est destinée au dépôt et à la diffusion de documents scientifiques de niveau recherche, publiés ou non, émanant des établissements d'enseignement et de recherche français ou étrangers, des laboratoires publics ou privés. 


\title{
The coupling of $\mathrm{CO}_{2}$ with diols promoted by organic dual systems: towards products divergence via benchmarking of the performance metrics
}

\author{
A. Brege ${ }^{a, b}$, R. Méreau ${ }^{a}, K^{2}$ McGehee ${ }^{a}$, B. Grignard ${ }^{b}$, C. Detrembleur ${ }^{b}$, C. Jerome ${ }^{b}, T$. \\ Tassainga* $^{a^{*}}$ \\ ${ }^{a}$ Institut des Sciences Moléculaires, UMR 5255 CNRS-Université de Bordeaux, 351, Cours de la \\ Libération, F-33405 Talence Cedex, France \\ ${ }^{\mathrm{b}}$ Center for Education and Research on Macromolecules (CERM), CESAM Research Unit, University of \\ Liege, Allée de la Chimie, B6a, 4000 Liège (Belgium). \\ Corresponding author: thierry.tassaing@u-bordeaux.fr
}

\section{ABSTRACT}

Herein, we propose a critical study balancing two metal-free dual activating systems, namely $\mathrm{DBU} / \mathrm{EtBr}$ and $\mathrm{TEA} / \mathrm{TsCl}$, for the coupling of $\mathrm{CO}_{2}$ with 1,x-diols to afford (a)cyclic carbonates. In-situ ATR-IR monitoring correlated with DFT calculations led to mechanism propositions for the model formation of propylene carbonate from propylene glycol. Kinetics upon various experimental conditions were established for the first time, leading to an optimized synthetic protocol. The substrates scope was then investigated and selectivities toward the formation of cyclic or linear carbonates were correlated to the dual activating system and the diol structure. By choosing the suitable organic dual activating system, one is able to control the product selectivity to substituted ethylene- or trimethylene carbonate and/or acyclic compounds, providing a powerful tool to synthesize $\mathrm{CO}_{2}$-based precursors that are highly relevant for organic and polymer chemistry from ubiquitous building blocks.

Keywords: Carbon dioxide, diols, carbonates, metal-free, mild conditions, selectivity

\section{Introduction}

It is widely known that carbon dioxide concentration in the atmosphere, among other greenhouse gases, keeps increasing every year, partly due to the petrochemical industry and combustion of fossil fuels.[1,2] New scientific challenges have risen to mitigate such anthropogenic emissions and prevent the environmental concerns. Among them, Carbon Dioxide Utilization (CDU) has emerged as a solution to valorise $\mathrm{CO}_{2}$ as a key intermediate for chemistry.[3-12] In this context, converting $\mathrm{CO}_{2}$ into organic cyclic carbonates was extensively investigated to design $\mathrm{CO}_{2}$-based materials with a lower carbon footprint finding wide applications as intermediates in the organic and polymer chemistry[13-21], as well as promising green aprotic polar solvents.[22,23] Various synthetic pathways were developed to access (functional) 5- or 6-membered cyclic carbonates such as the [3+2] coupling of $\mathrm{CO}_{2}$ with epoxides[24-29] or via the fixation of $\mathrm{CO}_{2}$ into oxetanes.[26,30,31] Although terminal epoxides are easily converted into 5-membered cyclic carbonates, the conversion of internal di-, triand tetra-substituted epoxides or (substituted) oxetanes into their corresponding five- and six-membered cycles still remained very challenging.[31] To broaden the scope and 
functionality of cyclic carbonates, other substrates such as propargylic alcohols[15,32-37], 1,2 and 1,3-diols[38-41] were subjected to carbonation in order to afford $\alpha$-alkylidene cyclic carbonates, five- and six-membered cyclic carbonates, respectively. Although the use of diols is a promising alternative, their reaction with $\mathrm{CO}_{2}$ is kinetically and thermodynamically limited due to the formation of water as a by-product. To surpass these hurdles, catalytic platforms based on both homogeneous and heterogeneous organometallic catalysts $\left(\mathrm{Bu}_{2} \mathrm{SnO}, \mathrm{K}_{2} \mathrm{CO}_{3}\right.$, $\mathrm{CeO}_{2} \ldots$ ) used in combination with dehydrating systems (molecular sieves, zeolites, 2Cyanopyridine...) were developed.[42,43] To the best of our knowledge, the most efficient system involved $\mathrm{CeO}_{2}$ as the catalyst and 2-Cyanopyridine as dehydrating agent. [43] The main drawback related to this process is the use of harsh reaction conditions ( $150{ }^{\circ} \mathrm{C}, 5 \mathrm{MPa}$ ) and an expensive dehydrating agent used in large excess. Alternative protocols have been recently proposed to displace the reaction equilibrium and to overcome the limitation induced by the formation of water by combining the use of an organic base and an alkylating agent under mild conditions. Such strategy has been shown by Zhang et al. [44] and Buchard et al. [45,46] by combining strong Lewis bases and Tosyl chloride $(\mathrm{TsCl})$ as the alkylating agent to promote the synthesis of 6-membered cyclic carbonates with the formation of the TsO- anion as a byproduct. A similar protocol has been proposed by Kitamura et al.[47] and Dyson et al. [41] using alkyl halides as the alkylating agents that allow the synthesis of cyclic carbonates in good yields from different substrates. Gnanou et al. also investigated the cyclization or polymerization of glycoside and diols with a larger spacer in a similar fashion. [48-50] Addition of ionic liquids to these systems to promote $\mathrm{CO}_{2}$ activation to afford cyclic carbonates from diols was also studied.[51] Although plausible mechanisms have been proposed for the carbonation of 1,2-diols promoted by organic bases/alkyl halide dual system, a molecular level understanding of the reaction mechanism and the determination of the key structural parameter of the reactants and the organic activating system that governs the yields and the selectivity of the reaction is still missing.

To this aim, we propose a detailed investigation and comparison of the coupling of $\mathrm{CO}_{2}$ and various $1, x$-diols in a one pot/one step fashion under mild conditions promoted by two different organic dual activating systems (Scheme 1).

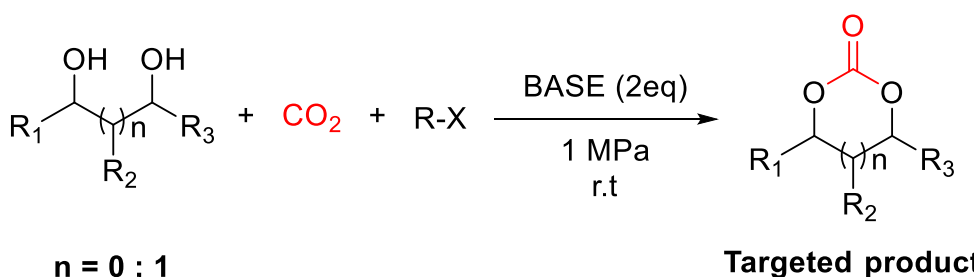

Scheme 1: Strategy for the synthesis of 5 to 6 membered cyclic carbonates from diols and $\mathrm{CO}_{2}$ promoted by organic bases and alkyl halides under mild conditions.

A mechanism of the model carbonation of propylene glycol using DBU and bromoethane is first proposed by correlation of in-situ ATR-IR kinetic monitoring and DFT calculations. The effects of the temperature, the pressure, the solvent and the nature of the alkyl halide on the kinetics, the carbonate yields and selectivities were then evaluated. In a similar fashion, the 
model carbonation of propylene glycol was studied using a second dual activating system with triethylamine (TEA) as a base and $\mathrm{TsCl}$ as the alkylating agent. Extension of the synthetic protocols to the carbonation of challenging mono-, di- and tetrasubstituted vicinal diols, to 1,3- and 1,4 diols or isosorbide, a bio-based diol with a two fused furan rings structure, was then investigated using both dual systems. The benchmarking of their performance metrics will guide us opting to the most appropriate activating system regarding the nature of the diol substrate and the desired product selectivity, i.e. a cyclic or a linear carbonate.

\section{Material and Methods}

\subsection{Material}

Propylene glycol (PG, Sigma Aldrich), Ethylene glycol (Sigma Aldrich), 2,3-butanediol (Sigma Aldrich), Pinacol (Sigma Aldrich), Glycerol (Sigma Aldrich), 1,3-butanediol (Sigma Aldrich), Hexylene glycol (Arkema), 1,4-butanediol (Sigma Aldrich), Isosorbide (Alfa Aesar), trans-1,2Cyclohexanediol (Alfa Aesar), Pyrocatechol (Sigma Aldrich), Bromoethane (Sigma Aldrich), Bromobutane (Sigma Aldrich), Chlorobutane (Sigma Aldrich), Benzyl bromide (Sigma Aldrich), Benzyl chloride (Sigma Aldrich), Methyl iodide (Sigma Aldrich), Dichloromethane $\left(\mathrm{CH}_{2} \mathrm{Cl}_{2}\right.$, Sigma Aldrich) Acetonitrile ( $\mathrm{CH}_{3} \mathrm{CN}$, Sigma Aldrich), Chloroform ( $\mathrm{CHCl}_{3}$ Sigma Aldrich), Anisole (Alfa Aesar), Dimethyl sulfoxide (DMSO, Sigma Aldrich) were used without further purification.

\subsection{Methods}

General procedure for kinetic studies:

The reactions were monitored in-situ by IR spectroscopy using a home-made Ge ATR accessory suitable for high-pressure measurements (up to $5 \mathrm{MPa}$ ) and high temperature (up to $100{ }^{\circ} \mathrm{C}$ ) coupled with a ThermoOptek interferometer (type 6700) equipped with a globar source, a $\mathrm{KBr} / \mathrm{Ge}$ beamsplitter and a DTGS (Deuterated TriGlycine Sulphate) detector. Single beam spectra recorded in the spectral range $\left(400-4000 \mathrm{~cm}^{-1}\right)$ with a $4 \mathrm{~cm}^{-1}$ resolution were obtained after the Fourier transformation of 20 accumulated interferograms for the first hundred spectra (one spectra every $75 \mathrm{sec}$ ), and then Fourier transformation of 80 accumulated intereferograms until the end of reaction time (one spectra every $5 \mathrm{~min}$ ).

Diol $(0.5 \mathrm{mmol})$ was solubilized in a $2 \mathrm{~mL}$ vial with $200 \mu \mathrm{L}$ of solvent. Organic base $(1 \mathrm{mmol})$ was added to the vial. Alkyl halide $(1.2 \mathrm{mmol})$ was added to the vial. The whole mixture was then transferred to the reaction chamber (volume: $5 \mathrm{~mL}$ ) which is directly fixed on the Ge crystal of the ATR-IR device. The setup is sealed with the $\mathrm{CO}_{2}$ feed pipe so it can be put under pressure. To best avoid side reactions between the base and the alkyl halide, it is worth noting that the faster the system is pressurized, the less side reactions are observed. Experiments where cyclic carbonates were obtained in good yields (> $50 \%$ ) were carried out again on a larger scale for further purification. Products were purified by column chromatography (100 \% Ethyl acetate for glycerol carbonate, 5 \% Acetone / $95 \%$ Chloroform for others) and weighted to get the isolated yield. 
General procedure for batch reactions:

Diol $(0.5 \mathrm{mmol})$ was solubilized in a $2 \mathrm{~mL}$ vial with $200 \mu \mathrm{L}$ of solvent. Organic base $(1 \mathrm{mmol})$ was added to the vial. Alkyl halide $(1.2 \mathrm{mmol})$ was added to the vial. A stir bar was added to the vial. The vial was sealed with a septum cap which was perforated to let $\mathrm{CO}_{2}$ enter the vial and dissolve in the solution. Up to 8 vials were transferred into the high pressure reacting chamber, placed on a magnetic stirrer. A pressure of $1 \mathrm{MPa} \mathrm{CO}_{2}$ was initially applied to the chamber, which volume is large enough to keep the pressure quasi constant throughout the reaction (pressure drops as $\mathrm{CO}_{2}$ dissolves in the media). At the end of the reaction time, the reaction chamber was slowly depressurized and the vials were taken out. Septum caps were replaced by sealed caps. All products were analysed by both ATR-IR spectroscopy and ${ }^{1} \mathrm{H}$ NMR spectroscopy without further purification. To best avoid side reactions between the base and the alkyl halide, it is worth noting that the faster the system is pressurized, the less side reactions are observed.

Nuclear magnetic resonance spectroscopy (NMR)

${ }^{1} \mathrm{H}$ and ${ }^{13} \mathrm{C}$ NMR spectra were recorded at $298 \mathrm{~K}$ with a Bruker advance DRX 400 spectrometer operating at $400.13 \mathrm{MHz}$, on the Fourier transform mode. All NMR spectra were phased and baseline-corrected. The samples were prepared by dissolving $15-20 \mathrm{mg}$ of product in $0.7 \mathrm{ml}$ of a deuterated solvent $\left(\mathrm{CDCl}_{3}\right)$ and were calibrated with the $7.26 \mathrm{ppm}$ residual signal of $\mathrm{CDCl}_{3}$.

Density Functional Theory (DFT) computational details

Preliminary calculations of equilibrium structures were performed using a semi-empirical model (AM1-D3H4) to determine the most stable conformations. These semi-empirical calculations were performed using the AMPAC software. The CHAIN algorithm was used for locating intermediates and transition states along the reaction path. The lowest energy structures obtained at the AM1-D3H4 level were further investigated using the Density Functional Theory method (DFT) implemented in the Gaussian 16 package. DFT calculations of geometries, energies, and vibrational frequencies reported in this article were carried out with the M06-2X functional using the $6-311 G(d, p)$ basis set. All frequencies of each structure have also been calculated to verify the presence of a single imaginary frequency for transition states and the absence of imaginary frequency for ground states. The intrinsic reaction coordinate (IRC) method has been used to verify that the obtained transition states were effectively connected to the desired minima. For all activating systems, a wide range of possible configurations and interactions have been modelled and the more stable of them are reported in this work. To consider entropic effects, the energies mentioned in this study correspond to the Gibbs free energy $(\Delta G)$.

\section{RESULTS AND DISCUSSION}

\subsection{Dual system DBU/R-X}

3.1.1 Synthesis of propylene carbonate from propylene glycol : mechanistic study 
Insights into the mechanisms and the kinetics of the carbonation of $1, x$-diols to access (a)cyclic carbonates were first performed for a model reaction between propylene glycol (PG) and $\mathrm{CO}_{2}$ promoted by a dual system composed of an organic superbase, i.e. 1,8-diazabicyclo-[5.4.0]undec-7-ene (DBU) and an alkylating agent, i.e. bromoethane (EtBr) (Scheme 2). The model reactions were performed in dichloromethane under low $\mathrm{CO}_{2}$ pressure $(0.5-4 \mathrm{MPa})$ and monitored by in-situ ATR-IR spectroscopy (Figure 1).

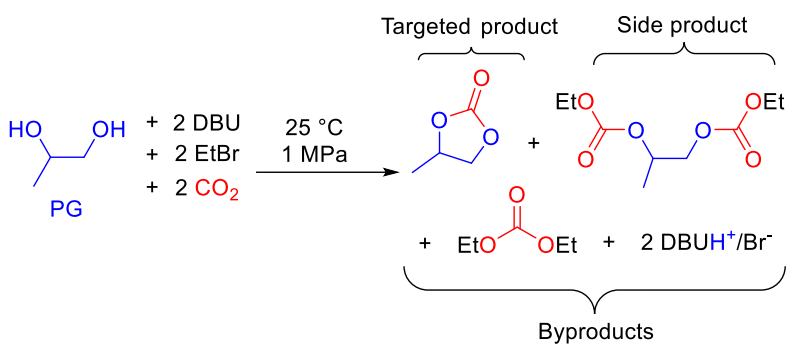

Scheme 2: One pot/one step model reaction studied for the synthesis of propylene carbonate from PG and $\mathrm{CO}_{2}$. Diethyl carbonate is obtained as a by-product.

Typical spectra recorded at different reaction times are depicted in Fig. 1. Fine interpretation of the spectral footprints enabled us to identify several key intermediates formed at $25^{\circ} \mathrm{C}$ under $1 \mathrm{MPaCO}$ pressure. First, before the introduction of $\mathrm{CO}_{2}$ in the reaction mixture, a welldefined band observed at $1613 \mathrm{~cm}^{-1}$ is characteristic of the $\mathrm{C}=\mathrm{N}$ stretching mode of $\mathrm{DBU}$ which indicates that there is no specific interaction and/or reaction between DBU and another reactive species (red curve). In particular, neither spontaneous deprotonation of the alcohol moiety by $\mathrm{DBU}$ nor a possible alkylation of $\mathrm{DBU}$ by $\mathrm{EtBr}$ were observed. Addition of $\mathrm{CO}_{2}$ to the system at $1 \mathrm{MPa}$ pressure (green curve) induced a DBU absorption band shifts toward 1636 $\mathrm{cm}^{-1}$, which has been assigned to the $\mathrm{C}=\mathrm{NH}^{+}$stretching mode of protonated DBU. $[52,53]$ Concomitantly, a shoulder of this broad peak appears around $1660 \mathrm{~cm}^{-1}$ and was attributed to the $\mathrm{C}=\mathrm{O}$ stretching of the alkyl carbonate anion $\mathrm{RCO}_{3}{ }^{-}$species.[53-55] These spectral changes highlight a trimolecular reaction between $\mathrm{CO}_{2}, \mathrm{PG}$ and $\mathrm{DBU}$ forming the $\mathrm{RCO}_{3}{ }^{-} / \mathrm{DBUH}^{+}$organic salt (see ESI 1 for further investigations). Indeed, the hydrogen bonding between $\mathrm{sp}^{2} \mathrm{~N}$ atom from $D B U$ and the alcohol moiety of PG will increase the nucleophilicity of the $\mathrm{O}$ atom and thus promotes its attack on the $\mathrm{C}$ atom of $\mathrm{CO}_{2}$. It should be noted that the formation of the carbonate salt occurs within 5 minutes and is regulated by the $\mathrm{CO}_{2}$ solubilisation in the organic phase, which is known to be high in dichloromethane. [56,57] By ATR-IR, it was however not possible to discriminate which of the primary or the secondary alcohol is preferentially involved in the formation of the carbonate salt. When the reaction goes on, around $30 \mathrm{~min}$ after introduction of $\mathrm{CO}_{2}$, the absorption band of protonated DBU starts shifting from 1636 $\mathrm{cm}^{-1}$ to higher wavenumbers of $1645 \mathrm{~cm}^{-1}$ (purple curve). The peak got thinner and the shoulder tended to disappear. This was attributed to a change in the anionic environment of protonated $\mathrm{DBU}$, due to the time consumption of the $\mathrm{RCO}_{3}{ }^{-}$species that are progressively replaced by the bromine anion of EtBr. Concomitantly, two novel absorption bands appeared around $1743 \mathrm{~cm}^{-1}$ and $1796 \mathrm{~cm}^{-1}$ and were respectively assigned to the $\mathrm{C}=\mathrm{O}$ stretching mode of a linear alkyl carbonate[58] IntLC (see Scheme 3) and to the vibrational stretching of the $\mathrm{C}=\mathrm{O}$ function of a 5-membered cyclic carbonate[58], i.e. propylene carbonate (PC) (See ESI 2). 


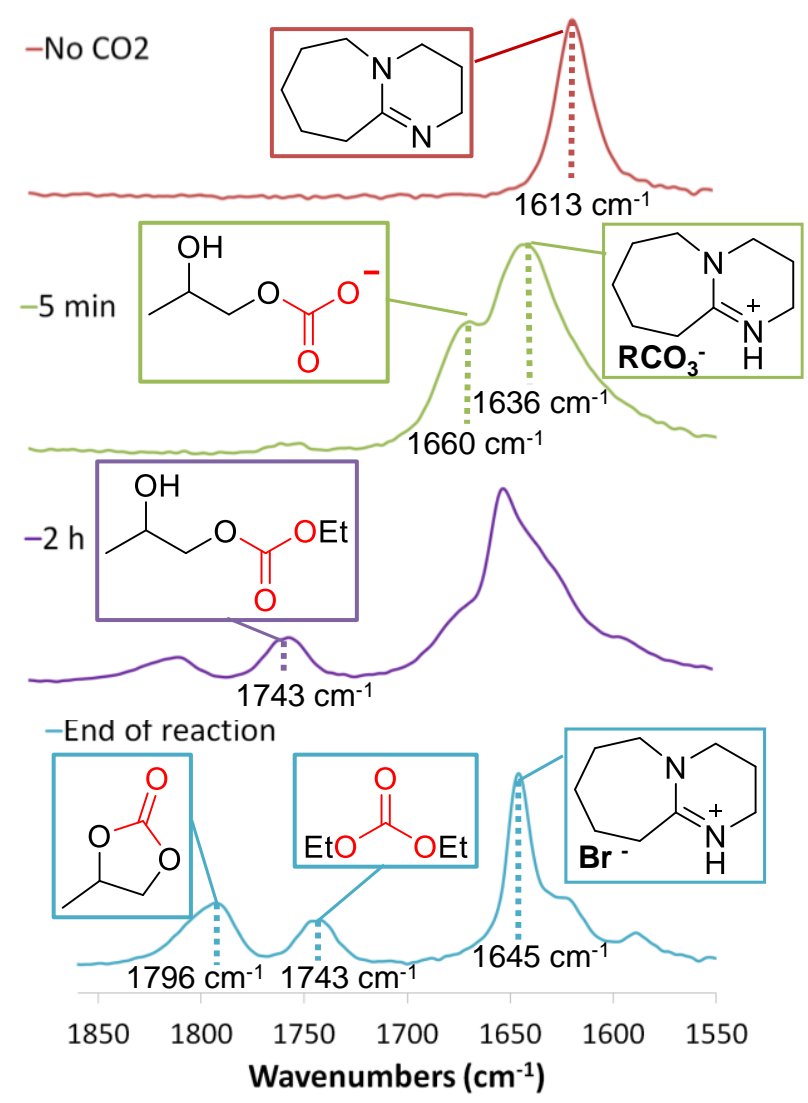

Figure 1: Monitoring of the model reaction between $\mathrm{PG}$ and $\mathrm{CO}_{2}$ promoted by a dual DBU/EtBr system using ATR-IR spectroscopy. Conditions: PG (0.5mmol); DBU (1mmol); $\mathrm{EtBr}(1.2 \mathrm{mmol}) ; \mathrm{CH}_{2} \mathrm{Cl}_{2}(200 \mu \mathrm{L}) ; 1 \mathrm{MPa} ; 25^{\circ} \mathrm{C}$<smiles>CCOC(=O)OCC(C)O</smiles><smiles>CCOC(=O)OCC(C)OC(=O)OCC(C)Br</smiles>

Scheme 3: Substrate (PG), reaction intermediates (IntLC ; IntCC) and products (PC; BisLC; DEC) of the model reaction

So far, the ATR-IR analysis could not differentiate IntLC from diethyl carbonate (DEC) coproduced at the end of the reaction. To get clues about the formation of DEC by-product, kinetic profiles were drawn from the time evolution of the intensity of the specific signals of both the linear and the cyclic carbonate (Fig. 2). As a matter of fact, the absorption band $\mathrm{v}_{\mathrm{c}=\mathrm{O}}$ $=1743 \mathrm{~cm}^{-1}$ of IntLC started increasing after only 5 min., i.e. far before the formation of PC $\left(v_{\mathrm{C}=0}=1796 \mathrm{~cm}^{-1}\right)$ that appears at $\mathrm{t}=60 \mathrm{~min}$, suggesting that $\mathrm{PC}$ is produced from IntLC. Then, one would expect that the consumption of IntLC should be accompanied with a progressive 
decrease of the intensity of the peak at $\mathrm{v}_{\mathrm{C}=0}=1743 \mathrm{~cm}^{-1}$. But, this specific signal reached a quasi-plateau as soon as PC started to be synthesized confirming that each mole of IntLC that is consumed produces PC but also one mole of DEC co-product, both intermediate IntLC and DEC having the same absorption band. We believe that the absorbance of the peak at $\mathrm{V}_{\mathrm{C}=\mathrm{O}}=$ $1743 \mathrm{~cm}^{-1}$ keeps increasing very slightly because of the formation of side products (See Scheme 2), namely BisLC (Scheme 3). Indeed, a linear biscarbonate BisLC, which absorption band of the $\mathrm{C}=\mathrm{O}$ stretching mode is around $1743 \mathrm{~cm}^{-1}$, is obtained in low yields ( 15\%) from carbonation of each alcohol moieties, followed by double alkylation. This study led to consistent proofs for the prior formation of IntLC before PC and DEC.

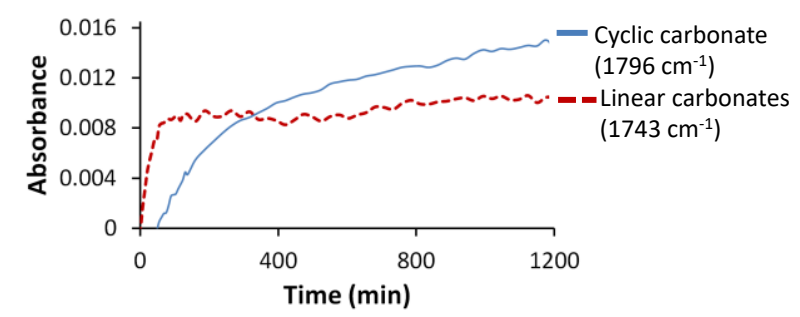

Figure 2: Kinetic study of the carbonation of PG promoted by DBU/EtBr system: time evolution of the absorption bands relative to PC and linear carbonates (DEC, IntLC and BisLC). Conditions: PG (0.5 mmol); DBU (1 mmol); EtBr (1.2 mmol); $\mathrm{CH}_{2} \mathrm{Cl}_{2}(200 \mu \mathrm{L}) ; 1 \mathrm{MPa} ; 25^{\circ} \mathrm{C}$

The ${ }^{1} \mathrm{H}$ NMR characterization of the crude reaction medium after $20 \mathrm{~h}$ confirmed the presence of $\mathrm{PC}, \mathrm{DEC}$ and BisLC (yield of $\mathrm{PC}=73 \%, \mathrm{PC} / \mathrm{DEC}=2$, yield of biscarbonated products $\mathrm{BisLC}=$ $15 \%$ ) (See ESI 3). Control experiment for the synthesis of DEC from ethanol and $\mathrm{CO}_{2}$ promoted by dual system composed of $\mathrm{DBU} / \mathrm{EtBr}$ in the same experimental conditions was carried out. DEC was obtained in $55 \%$ yield after $23 \mathrm{~h}$, which explain the origin of the PC/DEC ratio of 2 at the end of reaction time. The identification of the specific intermediates correlated to the kinetic data obtained through ATR-IR monitoring led to a mechanism proposal (Scheme 4).

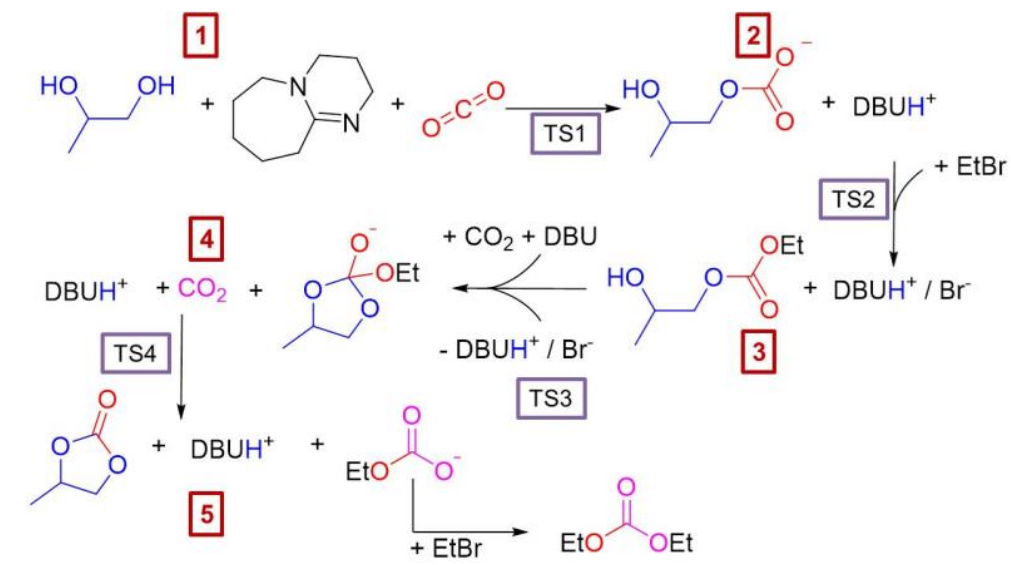

Scheme 4: Mechanism proposal for the formation of propylene carbonate from PG, based on reaction intermediates identified from Fig.1. The presence of IntCC was not shown by ATR-IR experiments but was proposed regarding DFT calculations (Fig. 3).

As proposed before, the first step relies on the carbonation of one alcohol moiety of PG to generate an alkyl carbonate ion $/ \mathrm{DBUH}^{+}$adduct. The second step consists of a $\mathrm{SN}_{2}$ addition of the generated alkyl carbonate ion on $\mathrm{EtBr}$, leading to the linear alkyl carbonate IntLC. Then, a 
second equivalent of DBU creates an hydrogen bonding with the second alcohol moiety rendering the oxygen atom more reactive and capable of an intramolecular attack onto the carbonyl group of the acyclic carbonates. This reaction generates the cyclic intermediate IntCC that expelled ethanolate with concomitant formation of propylene carbonate. Ethanolate undergoes a carbonation reaction with the $\mathrm{CO}_{2}$ dissolved in the medium to generate an anionic alkyl carbonate, which will react with a second equivalent of $\mathrm{EtBr}$ through a $\mathrm{SN}_{2}$ reaction to generate the acyclic diethyl carbonate as a co-product.

To confirm our predictions deduced from the experimental ATR-IR results, this mechanism was confronted to molecular modelling through DFT calculations at the M062X/6-311g(d,p) level (Fig. 3). As expected from experimental results, TS1 involves a trimolecular reaction

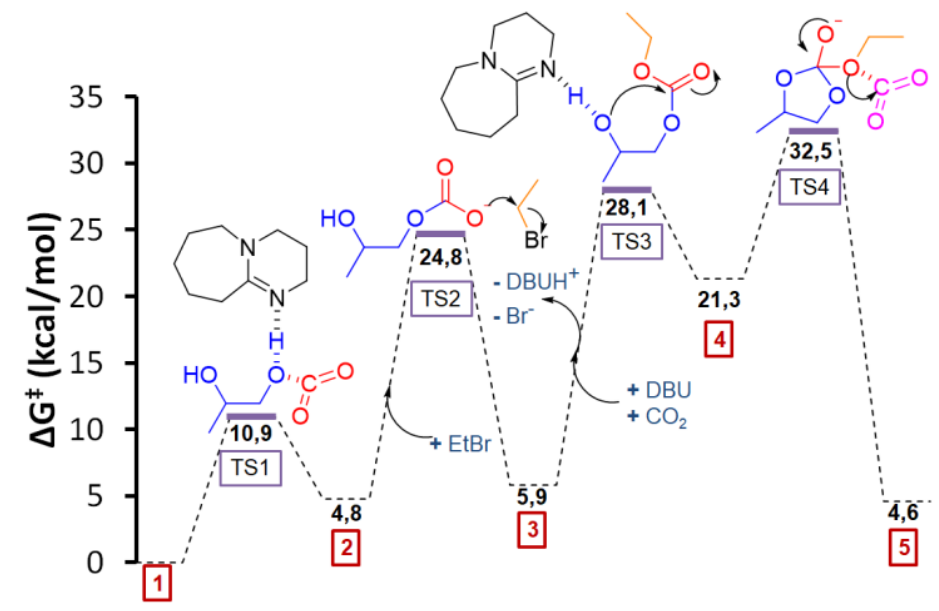

Figure 3: DFT computed pathway $(M 062 X / 6-311 g(d, p))$ of model reaction as depicted in Scheme 4. Red numbers correspond to optimized reaction intermediates shown in Scheme 4 (Van Der Waals interactions were accounted). Transition states (TS) were optimized using the same molecular species as in the intermediates.

through hydrogen bonding which activates the alcohol function and induces angular deformation of $\mathrm{CO}_{2}\left(\Delta \mathrm{G}_{\mathrm{TS} 1}{ }^{\ddagger}=10.9 \mathrm{kcal} / \mathrm{mol}\right)$. TS2 confirms the $\mathrm{SN}_{2}$ hypothesis on $\mathrm{EtBr}$ with simultaneous addition of $\mathrm{RCO}_{3}{ }^{-}$and elimination of $\mathrm{Br}^{-}\left(\Delta \mathrm{G}_{\mathrm{TS} 2}{ }^{\ddagger}=20.0 \mathrm{kcal} / \mathrm{mol}\right)$. TS3 involves another hydrogen bonding to promote the cyclization $\left(\Delta \mathrm{G}_{\mathrm{TS} 3}{ }^{\ddagger}=22.2 \mathrm{kcal} / \mathrm{mol}\right)$. Finally, TS4 is related to the cyclization of propylene carbonate with the release of an ethyl carbonate anion formed from the addition of an excess $\mathrm{CO}_{2}$ to the released ethanolate. Thus, although DFT calculation results show that the cyclization (TS3) and the formation of the cyclic carbonate (TS4) are two different steps, the intermediate IntCC was not identified by ATR-IR spectroscopy probably due to the high Gibbs Free Energy of intermediate 4 and the low activation barrier of TS4 $\left(\Delta \mathrm{GTS}_{\mathrm{TS}}{ }^{\ddagger}=11.2 \mathrm{kcal} / \mathrm{mol}\right)$.

The low activation barrier of $\Delta \mathrm{GTS}_{1}{ }^{\ddagger}$ is well correlated with the fast formation of the anionic alkyl carbonate $\mathrm{RCO}_{3}^{-}$( $5 \mathrm{~min}$ for carbonation of the alcohol moiety). As IntLC is very stable (linear alkyl carbonate), $\Delta \mathrm{G}_{\mathrm{TS3}}{ }^{\ddagger}$ has the highest activation barrier and is thus the rate limiting step of the reaction. Once again, it is well correlated with kinetic profiles obtained by ATR-IR, since absorption band of IntLC $\left(\mathrm{v}_{\mathrm{C}=0}=1743 \mathrm{~cm}^{-1}\right)$ appears before and increases faster than absorption band of the cyclic product $\left(\mathrm{v}_{\mathrm{c}=\mathrm{O}}=1796 \mathrm{~cm}^{-1}\right)$. 
It should be noted that the DFT energetic profile of Fig. 3 was modelled with (R)-1,2propanediol and assuming that the carbonation would first occur on the primary alcohol function. Yet, all the possible reaction pathways were modelled for both the (R) and $(S)$ stereoisomers of propylene glycol and by assuming either the carbonation of the primary or secondary alcohol upon $\mathrm{CO}_{2}$ addition (see ESI 4). No major differences in the activation barrier of each transition states were found, and we concluded that all paths could occur, with a slight preference over carbonation of primary alcohol of (R)-1,2-propanediol (see ESI 4). To further understand how the experimental parameters may affect the DBU-promoted carbonation of $1, x$-diols, the influences of the temperature, the pressure, the solvent, the alkylating agent and the substrate scope were investigated through ATR-IR and results were complemented by quantitative ${ }^{1} \mathrm{H}$ NMR characterization of the crude media (see ESI 3 and ESI 5). Full conversion of the diol was never observed. In most of the spectra, a small fraction of the intermediate IntLC obtained from the corresponding 1,x-diol remained not converted into the cyclic product.

\subsubsection{Temperature, pressure and solvent effect on kinetics and yields}

\section{Effect of the temperature:}

At a fixed pressure of $1 \mathrm{MPa}$, an increase of the temperature from $25{ }^{\circ} \mathrm{C}$ to $50{ }^{\circ} \mathrm{C}$ slightly increases the overall yield (from $70 \%$ to $76 \%$ after $20 \mathrm{~h}$ ) but considerably increases the kinetics (Table 1, entries 1-2). Fig. 4a (green curve) highlights a two-fold acceleration of the formation of propylene carbonate by simple doubling of the temperature. In contrast, heating up to 70 ${ }^{\circ} \mathrm{C}$ do not increase the kinetic of the reaction but has a detrimental effect on the yield (Table 1 , entry 3 ; Fig. 4 a, red curve). In both cases, increasing the temperature led to lower yields of BisLC biscarbonated side-products $\left(2 \%\right.$ and $5 \%$ for $50{ }^{\circ} \mathrm{C}$ and $70{ }^{\circ} \mathrm{C}$ respectively).

Table 1: Effect of the temperature, pressure and solvent on the reaction of propylene glycol to afford propylene carbonate. Reaction conditions: Propylene glycol ( $0.5 \mathrm{mmol}$ in $200 \mu \mathrm{L}$ solvent), DBU (1 mmol), $\mathrm{EtBr}(1.2 \mathrm{mmol})$.

\begin{tabular}{cccc|ccc}
\hline Entry & $\begin{array}{c}\mathrm{P} \text { co2 } \\
(\mathrm{MPa})\end{array}$ & $\begin{array}{c}\mathrm{T} \\
\left({ }^{\circ} \mathrm{C}\right)\end{array}$ & Solvent & $\begin{array}{c}\text { PG conv. } \\
(\%)^{1,2}\end{array}$ & $\begin{array}{c}\text { PC yield } \\
(\%)^{1,3}\end{array}$ & $\begin{array}{c}\text { Biscarbonate } \\
\text { yield }(\%)^{1,4}\end{array}$ \\
\hline 1 & 1 & 25 & $\mathrm{CH}_{2} \mathrm{Cl}_{2}$ & 90 & 73 & 15 \\
2 & 1 & 50 & $\mathrm{CH}_{2} \mathrm{Cl}_{2}$ & 78 & 76 & 2 \\
3 & 1 & 70 & $\mathrm{CH}_{2} \mathrm{Cl}_{2}$ & 70 & 49 & 5 \\
\hline 4 & 0.5 & 25 & $\mathrm{CH}_{2} \mathrm{Cl}_{2}$ & 74 & 62 & 12 \\
5 & 2 & 25 & $\mathrm{CH}_{2} \mathrm{Cl}_{2}$ & 40 & 35 & 0 \\
6 & 3 & 25 & $\mathrm{CH}_{2} \mathrm{Cl}_{2}$ & 20 & 16 & 2 \\
7 & 4 & 25 & $\mathrm{CH}_{2} \mathrm{Cl}_{2}$ & 41 & 34 & 7 \\
\hline 8 & 1 & 25 & neat & 87 & 61 & 26 \\
\hline 9 & 3 & 25 & neat & 56 & 22 & 22 \\
\hline 10 & 1 & 25 & anisole & 72 & 46 & 16 \\
\hline 11 & 1 & 25 & $\mathrm{ACN}$ & 78 & 30 & 19 \\
\hline 12 & 1 & 25 & $\mathrm{CHCl}_{3}$ & 70 & 45 & 10 \\
\hline 13 & 1 & 25 & DMSO & 69 & 15 & 14 \\
\hline
\end{tabular}


${ }^{1}$ Determined after $20 \mathrm{~h}$

${ }^{2}$ Conversion of propylene glycol calculated from ${ }^{1} \mathrm{H}$ NMR with 1,3,5-trimethoxybenzene as internal standard

${ }^{3}$ PC yield calculated from ATR-IR and from ${ }^{1} \mathrm{H}$ NMR with 1,3,5-trimethoxybenzene as internal standard

${ }^{4}$ Yield of the biscarbonated product BisLC calculated from ${ }^{1} \mathrm{H}$ NMR with 1,3,5-trimethoxybenzene as internal standard
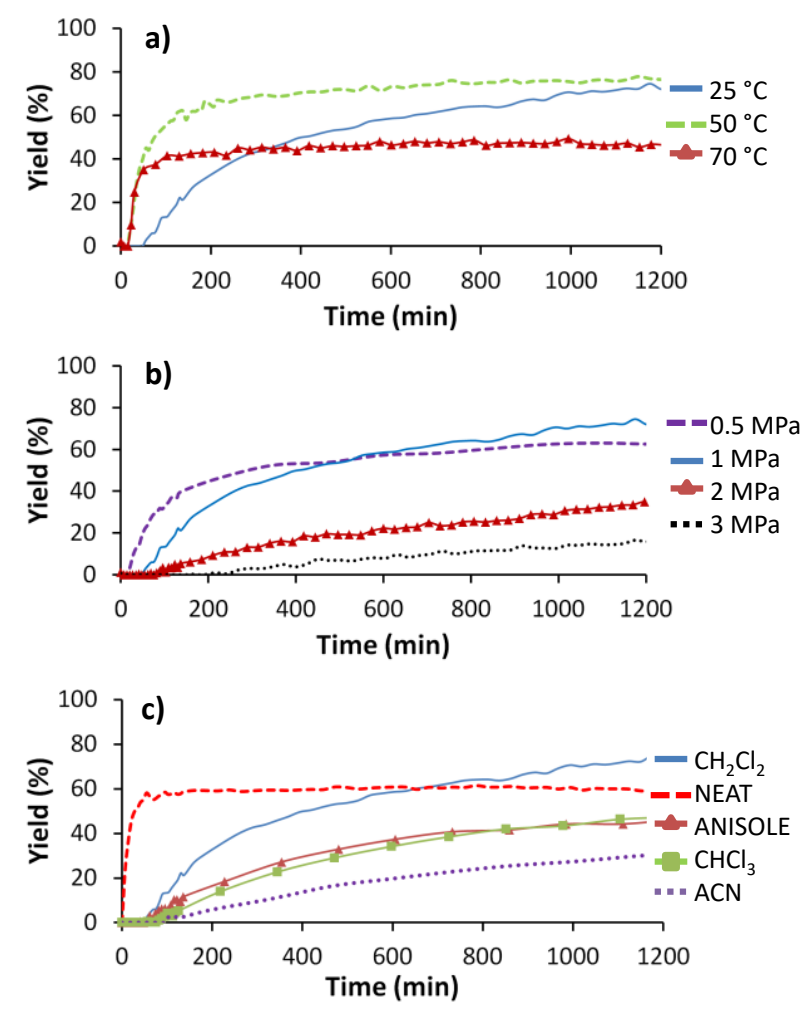

Figure 4 : Yield of propylene carbonate (PC) with the reaction time for different (a) temperatures, (b) pressures and (c) solvent conditions. Reaction conditions are described in Table 1.

\section{Effect of the pressure:}

Increasing the pressure from $1 \mathrm{MPa}$ to $4 \mathrm{MPa}$ had a detrimental effect on both the kinetics and $\mathrm{PC}$ yields for the model reaction promoted by $\mathrm{DBU} / \mathrm{EtBr}$ in $\mathrm{CH}_{2} \mathrm{Cl}_{2}$ at $25^{\circ} \mathrm{C}$ for $20 \mathrm{~h}$ (Figure $4 \mathrm{~b})$. While the $\mathrm{CO}_{2}$ solubility increases with the pressure in $\mathrm{CH}_{2} \mathrm{Cl}_{2}$ [56], a two-fold decrease of the reaction yield ( $P C$ yields from $70 \%$ to $35 \%$, Table 1, entries 1 and 5 ) was noticed upon simple doubling the $\mathrm{CO}_{2}$ pressure from $1 \mathrm{MPa}$ to $2 \mathrm{MPa}$ and the reaction was quasi inhibited at $3 \mathrm{MPa}$ of $\mathrm{CO}_{2}$. Such experimental observations were assigned to a "salting out effect" presumably caused by the formation of a $\mathrm{CO}_{2}$-expanded reaction medium provoking the precipitation of the $\mathrm{RCO}_{3}{ }^{-} / \mathrm{DBUH}^{+}$organic salt (see ESI 6). Attempts to improve the addition of $\mathrm{CO}_{2}$ onto $\mathrm{PG}$ by decreasing the pressure from $1 \mathrm{MPa}$ to $0.5 \mathrm{MPa}$ also gave mitigated results. If the kinetic is faster during initial course of the reaction (below $500 \mathrm{~min}$ ) at $0.5 \mathrm{MPa}$, the PC yield ceiled at 50-60\% after 500-600 min while it continued to increase up to 70 \% at $1 \mathrm{MPa}$. Therefore, we set up the optimal pressure and temperature for this reaction in $\mathrm{CH}_{2} \mathrm{Cl}_{2}$ to 1 $\mathrm{MPa}$ and $25^{\circ} \mathrm{C}$, respectively. Regarding the formation of BisLC side product, lower yields were unexpectedly obtained with higher pressures, which indicate that the $\mathrm{CO}_{2}$ concentration in the reaction mixture is not decisive for this side reaction. 


\section{Effect of the solvent:}

To study the influence of the solvent on the system, the model reactions were reproduced at $1 \mathrm{MPa}$ and $25^{\circ} \mathrm{C}$ in neat condition or using anisole, $\mathrm{CHCl}_{3}, \mathrm{DMSO}$ or acetonitrile (ACN) (Table 1 , entries 8-13). Even though $\mathrm{CO}_{2}$ is poorly soluble in glycols [59], reactions performed under neat conditions at $1 \mathrm{MPa}$ and $25^{\circ} \mathrm{C}$ displayed faster kinetics, and PC yields up to $60 \%$ were obtained after only $2 \mathrm{~h}$ (Table 1 , entry 8 , Fig. $4 \mathrm{C}$ red curve). Alike the model reactions carried out in $\mathrm{CH}_{2} \mathrm{Cl}_{2}$, increasing the pressure had a negative impact on both the kinetic and PC yields (Table 1, entries 8-9). Switching from $\mathrm{CH}_{2} \mathrm{Cl}_{2}$ to other solvents (Table 1, entries 10-13) led systematically to lower/moderate PC yields (from $16 \%$ in DMSO to $46 \%$ in anisole after $20 \mathrm{~h}$ ). The benchmarking of the kinetic profiles recorded for each solvent clearly highlighted slower reaction rates in solvents other than $\mathrm{CH}_{2} \mathrm{Cl}_{2}$ (Fig. $4 \mathrm{C}$ ). Interestingly, when the reaction was carried out in anisole, precipitation of organic salts $\mathrm{DBUH}^{+} / \mathrm{Br}^{-}$occurred after $30 \mathrm{~min}$ of reaction. When DMSO was used instead of $\mathrm{CH}_{2} \mathrm{Cl}_{2}$, $\mathrm{PC}$ was synthesized in very low yield (Table 1 , entry 15). We believe the variation of the PC yields in the various solvents was caused by the occurrence of side-reactions (enhanced alkylation of DBU by $\mathrm{EtBr}$ ), that will be discussed below. Unlike neat conditions that favoured the formation of BisLC side-product with a yield up to $27 \%$ (Table 1, entry 8-11), its formation remained limited to $15 \%$ by switching from $\mathrm{CH}_{2} \mathrm{Cl}_{2}$ to other solvents.

\section{Influence of the alkylating agent:}

As shown by our DFT calculations, the R-X alkylating agent is expected to play an important role on the carbonation of diols. It was expected that the nature of the halide would dictate the reactivity for the alkylation of the carbonate anion (step 2 in Scheme 4) whereas the $R$ motif is expected to trigger the cyclization step prior formation of PC by providing a good ROleaving group (step 4 in Scheme 4). To verify this hypothesis, different alkyl halides were screened for the DBU promoted synthesis of PC from $\mathrm{PG}$ and $\mathrm{CO}_{2}$ at $25^{\circ} \mathrm{C}$ and $1 \mathrm{MPa}$ in $\mathrm{CH}_{2} \mathrm{Cl}_{2}$. When bromobutane replaced bromoethane, a slower kinetic was observed (Fig. 5, dark red curve), resulting in lower PC yield of $50 \%$ after $20 \mathrm{~h}$ (Table 2, entry 2). Extending the reaction time to $39 \mathrm{~h}$ led to similar yield with regard to bromoethane ( $76 \%$ yield of PC). Replacing bromobutane by its chlorinated analogue dramatically decreased the reaction rate with a marginal PC yield of only $3 \%$ after $20 \mathrm{~h}$ (Table 2, entries 2 and 3, Fig. 5 orange curve). This result is consistent with the proposed mechanism that involved the formation of the intermediate IntLC by a $\mathrm{SN}_{2}$ reaction (step 2, see Scheme 4). Chlorine being a poorer leaving group than bromine, the nucleophilic substitution is disfavoured.

Table 2 : Effect of the alkyl halide on the carbonation of propylene glycol under a pressure of $1 \mathrm{MPa}^{\mathrm{CO}} \mathrm{CO}_{2}$ at 25 ${ }^{\circ} \mathrm{C}$. Reaction conditions: diol $\left(0.5 \mathrm{mmol}\right.$ in $\left.200 \mu \mathrm{L} \mathrm{CH}_{2} \mathrm{Cl}_{2}\right)$, DBU (1 mmol), Alkyl halide R-X (1.2 mmol)

\begin{tabular}{cc|ccc}
\hline Entry & R-X & $\begin{array}{c}\text { PG conv. } \\
(\%)^{1,2}\end{array}$ & $\begin{array}{c}\text { PC yield } \\
(\%)^{1,3}\end{array}$ & $\begin{array}{c}\text { Biscarbonate } \\
\text { yield }(\%)^{1,4}\end{array}$ \\
\hline 1 & $\mathrm{EtBr}$ & 90 & 73 & 15
\end{tabular}




\begin{tabular}{cc|ccc}
2 & $\mathrm{BuBr}$ & 60 & 50 & 10 \\
3 & $\mathrm{BuCl}$ & 3 & 3 & 0 \\
4 & $\mathrm{BzCl}$ & 65 & 65 & 0 \\
5 & $\mathrm{BzBr}$ & 0 & 0 & 0 \\
6 & $\mathrm{Mel}$ & 0 & 0 & 0 \\
$7^{\mathrm{a}}$ & $\mathrm{EtBr}$ & 28 & 10 & 0 \\
$8^{\mathrm{b}}$ & $\mathrm{EtBr}$ & 35 & 32 & 0 \\
$9^{\mathrm{c}}$ & $/$ & 3 & 3 & 0 \\
\hline
\end{tabular}

\footnotetext{
${ }^{1}$ Determined after $20 \mathrm{~h}$

${ }^{2}$ Conversion of propylene glycol calculated from ${ }^{1} \mathrm{H}$ NMR with 1,3,5-trimethoxybenzene as internal standard

${ }^{3}$ PC yield calculated from ATR-IR and from ${ }^{1} \mathrm{H}$ NMR with 1,3,5-trimethoxybenzene as internal standard

${ }^{4}$ Yield of the biscarbonated product BisLC calculated from ${ }^{1} \mathrm{H}$ NMR with 1,3,5-trimethoxybenzene as internal standard

a $0.5 \mathrm{mmol}$ DBU.

b $0.5 \mathrm{mmol}$ R-X.

c No R-X.
}

Unlike chlorobutane, a higher PC yield of $65 \%$ was obtained with benzyl chloride. Indeed, the benzyl group displays better leaving group capability in comparison with the butyl group for the cyclization step. Surprisingly, with the more reactive benzyl bromide $(\mathrm{BzBr})$ or methyl iodide (Mel), no PC was formed (Table 2, entries 5-6). We therefore postulate that the possible quaternization of DBU by these alkyl halides might explain this lack of reactivity. This quaternization is typically used for the synthesis of ionic liquids[60]. This hypothesis was further confirmed by ATR-IR analysis. The $\mathrm{C}=\mathrm{N}$ stretching mode at $1613 \mathrm{~cm}^{-1}$ of DBU shifts toward $1622 \mathrm{~cm}^{-1}$ upon alkylation (see ESI 7) and is favoured with more reactive alkyl halides. From these experiments, $\mathrm{BzCl}$ and $\mathrm{EtBr}$ are the best candidates in combination with $\mathrm{DBU}$ for the synthesis of PC. Still, presence of quaternized DBU salts can be shown at the end of reaction time in Fig. 1 with a shoulder at $1622 \mathrm{~cm}^{-1}$ of the protonated-DBU peak, probably due to the presence of an excess of alkylating agent $(2.4 \mathrm{eq})$ and non-reacted base (diol not fully converted). Control experiments (Table 2, entries 7-8) highlighted the need of using 2 equivalents of $\mathrm{DBU}$ and 2.4 equivalents of $\mathrm{R}-\mathrm{X}$ to reach the highest $\mathrm{PC}$ high yields, as previously described. [47] In the absence of alkylating agent, only traces of PC (yield of $3 \%$, Table 2, entry 9) was measured, excluding any role of $\mathrm{CH}_{2} \mathrm{Cl}_{2}$ as an alkylating agent in promoting the carbonation of PG.

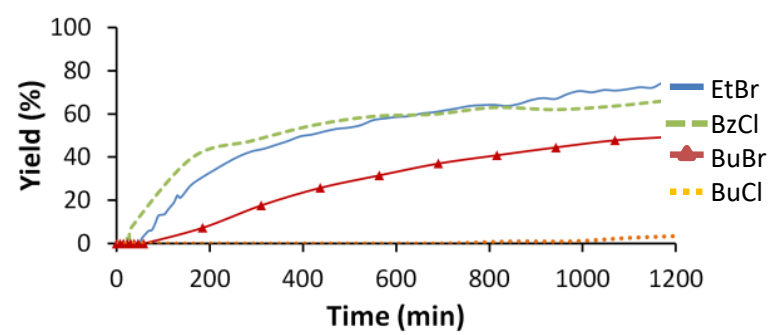

Figure 5: Yield of propylene carbonate $(P C)$ with the reaction time for different alkylating agents. Reaction conditions: Propylene glycol $\left(0.5 \mathrm{mmol}\right.$ in $\left.200 \mu \mathrm{L} \mathrm{CH}_{2} \mathrm{Cl}_{2}\right)$, DBU $(1 \mathrm{mmol}), \mathrm{R}-\mathrm{X}(1.2 \mathrm{mmol}), 1 \mathrm{MPa}, 25^{\circ} \mathrm{C}, 20 \mathrm{~h}$. One pot/one step reactions. 


\subsection{Dual system TEA/TsCl}

To increase the versatility of the coupling between diols and $\mathrm{CO}_{2}$ for the synthesis of cyclic carbonates, other tertiary amines than DBU were tested as bases, such as $N, N, N^{\prime}, N^{\prime}$ tetramethylethylenediamine (TMEDA), triethylamine (TEA), N,N-diisopropylethylamine (DIPEA) and N-methyl pyrrolidine. In all cases, carbonation of the alcohol of PG occurred as highlighted by in-situ ATR-IR by the formation of $\mathrm{RCO}_{3}{ }^{-}$species at $1660 \mathrm{~cm}^{-1}$. But no propylene carbonate was formed when EtBr was used as alkylating agent. Surprisingly, no absorption band could be observed around $1743 \mathrm{~cm}^{-1}$, indicating that step $2\left(\mathrm{SN}_{2}\right.$ reaction with $\left.\mathrm{EtBr}\right)$ did not occur. Further investigations were carried out with TEA as the model organic base to compare with DBU, using PG as the diol. DFT calculations (Fig. 6) showed that TEA poorly stabilises TS2, rendering the oxygen atom involved in $\mathrm{SN}_{2}$ less reactive than in the case of DBU (Mulliken charges of -0.451 vs -0.467), highlighting the important role of the base in every step of the reaction and not only for the protonation steps. This leads to a consistent increase of the Gibbs Free Energy of TS2 for TEA ( $36.5 \mathrm{kcal} / \mathrm{mol}$ vs $24.8 \mathrm{kcal} / \mathrm{mol})$ which is now the highest energetic barrier of the overall reaction $\left(\Delta \mathrm{G}_{\mathrm{TS} 2}{ }^{\ddagger}=27.4 \mathrm{kcal} / \mathrm{mol}\right)$, explaining why $\mathrm{SN}_{2}$ doesn't occur in the case of TEA and EtBr.

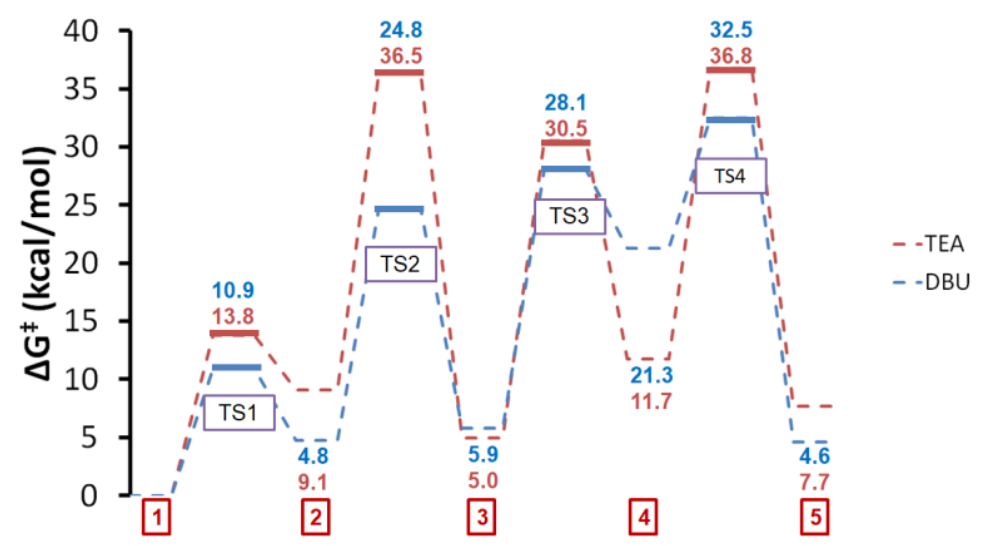

Figure 6: DFT computed pathway $(M 062 X / 6-311 g(d, p))$ of model reaction as depicted in Scheme 4 with two different organic bases (DBU or TEA). Red squares correspond to optimized reaction intermediates shown in Scheme 4 (Van Der Waals interactions were accounted). Transition states (TS) were optimized using the same molecular species as in the intermediates.

TEA being a less nucleophilic base than DBU, other more reactive $\mathrm{R}-\mathrm{X}$ could be tested while avoiding side reactions mentioned above (quaternization of the base). Tosyl chloride ( $\mathrm{TsCl}$ ) was selected as a good candidate due to previous research [44-46]. Similarly to the synthetic pathway with $\mathrm{DBU} / \mathrm{EtBr}$, the model carbonation reaction of propylene glycol into propylene carbonate was studied using the dual system TEA/TsCl. As the mechanism was already demonstrated by Buchard et a/[45] for the carbonation of 2,2-dimethyl-1,3-propanediol, the experimental confirmation of this mechanism is presented in ESI 8 with propylene glycol. Kinetic studies are reported for the first time by ATR-IR in-situ monitoring in pressurized reactors that enabled to identify important reaction intermediates and to confirm the reaction mechanism.

At room temperature and a fixed pressure of $1 \mathrm{MPa}$, a maximum PC yield of $79 \%$ is obtained after only $70 \mathrm{~min}$ (Fig. $7 \mathrm{a}$, blue curve). When the reaction media was heated up to $50{ }^{\circ} \mathrm{C}$ and $70{ }^{\circ} \mathrm{C}$, the yield decreased to $70 \%$ and $60 \%$ respectively (Table 3, entries $2-3$ ). 
Table 3: Effect of the temperature, pressure and solvent on the reaction of propylene glycol to afford propylene carbonate Reaction conditions: Propylene glycol $(0.5 \mathrm{mmol}$ in $200 \mu \mathrm{L}$ solvent), TEA ( $1 \mathrm{mmol}), \mathrm{TsCl}(0.5 \mathrm{mmol})$.

\begin{tabular}{cccc|cc}
\hline Entry & $\begin{array}{c}\mathrm{P}_{\mathrm{CO} 2} \\
(\mathrm{MPa})\end{array}$ & $\begin{array}{c}\mathrm{T} \\
\left({ }^{\circ} \mathrm{C}\right)\end{array}$ & Solvent & $\begin{array}{c}\text { PG conv. } \\
(\%)^{1,2}\end{array}$ & $\begin{array}{c}\text { PC yield } \\
(\%)^{1,3}\end{array}$ \\
\hline 1 & 1 & 25 & $\mathrm{CH}_{2} \mathrm{Cl}_{2}$ & 80 & 79 \\
2 & 1 & 50 & $\mathrm{CH}_{2} \mathrm{Cl}_{2}$ & 79 & 70 \\
3 & 1 & 70 & $\mathrm{CH}_{2} \mathrm{Cl}_{2}$ & 62 & 60 \\
\hline 4 & 0.5 & 25 & $\mathrm{CH}_{2} \mathrm{Cl}_{2}$ & 80 & 62 \\
5 & 2 & 25 & $\mathrm{CH}_{2} \mathrm{Cl}_{2}$ & 66 & 65 \\
6 & 3 & 25 & $\mathrm{CH}_{2} \mathrm{Cl}_{2}$ & 70 & 68 \\
7 & 4 & 25 & $\mathrm{CH}_{2} \mathrm{Cl}_{2}$ & 70 & 55 \\
\hline 8 & 1 & 25 & neat $^{2}$ & 90 & 90 \\
\hline 9 & 1 & 25 & anisole & 90 & 85 \\
\hline 10 & 1 & 25 & ACN & 80 & 75 \\
\hline 11 & 1 & 25 & $\mathrm{CHCl}_{3}$ & 79 & 60 \\
\hline 1
\end{tabular}

${ }^{1}$ Determined after $3 \mathrm{~h}$

${ }^{2}$ Conversion of propylene glycol calculated from ${ }^{1} \mathrm{H}$ NMR with 1,3,5-trimethoxybenzene as internal standard

${ }^{3}$ PC yield calculated from ATR-IR and from ${ }^{1} \mathrm{H}$ NMR with 1,3,5-trimethoxybenzene as internal standard
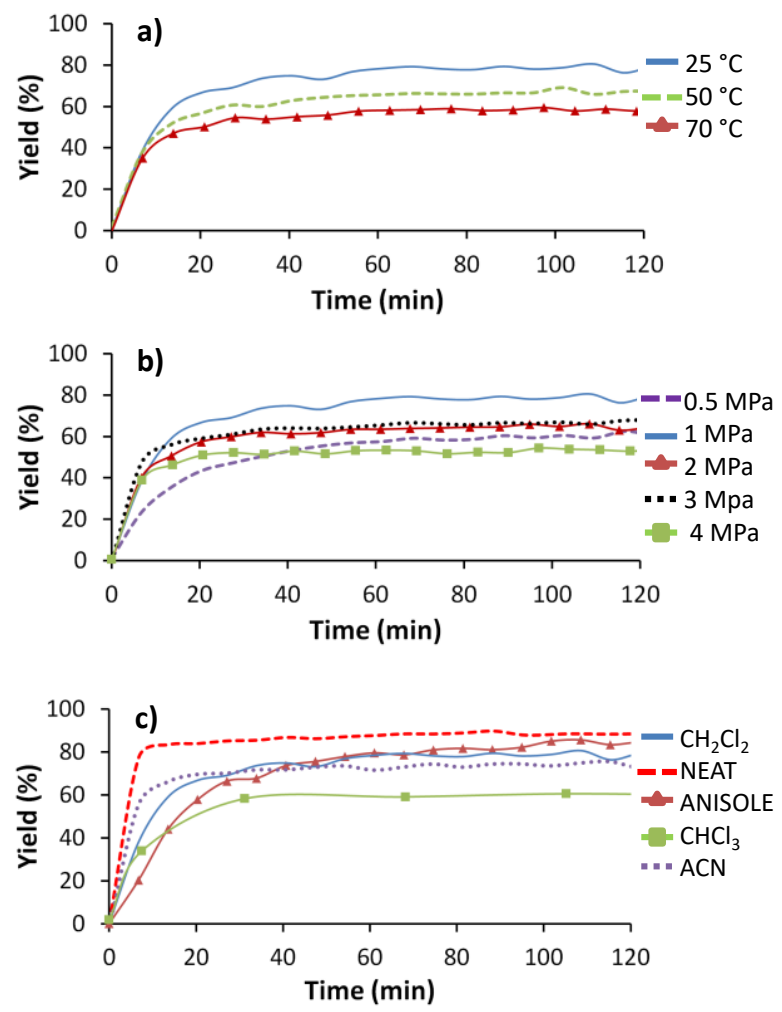

Figure 7: Yield of propylene carbonate (PC) with the reaction time for different (a) temperatures, (b) pressures and (c) solvent conditions. Reaction conditions are described in Table 3.

Regarding pressure effects, at the optimized temperature of $25^{\circ} \mathrm{C}$, an optimum yield for 1 MPa was observed (Table 3, entry 1 and entries 4-7) and increasing the pressure had a detrimental effect on the overall PG conversion and yield. No major differences were observed in terms of kinetics for both heating and increasing the pressure (Fig 7a and 7b), unless for a low pressure of $0.5 \mathrm{MPa}$ (Fig 7b, purple curve) that displayed slow kinetics. 
The optimized conditions were applied in neat conditions, which gave the best results so far with $90 \%$ PC yield after only 70 min (Fig 7c, red dashed curve; Table 3, entry 8). Other solvents were tested resulting in a drop of the PC yields to $85 \%$ in anisole (Table 3, entry 9). Switching to acetonitrile or $\mathrm{CHCl}_{3}$ gave PC yields of $75 \%$ and $60 \%$ respectively (Table 3, entries 10-11), with slower kinetics in chloroform (Fig 7c, green curve).

As for the $\mathrm{DBU} / \mathrm{EtBr}$ dual system, side reactions are expected. In this case, with propylene glycol as a substrate, the main side reaction is the tosylation of one or both alcohol groups, as it is a known reaction for protecting alcohol groups in organic chemistry when a base is involved. Nevertheless, yields of tosylated alcohol never exceeded $3 \%$ for all experiments listed in Table 3.

Other kinetics were performed with tertiary amines such as DIPEA, TMEDA and N-methyl pyrrolidine. Best results were obtained with TEA when dichloromethane was used as solvent. Still, DIPEA could afford propylene carbonate with a yield of $75 \%$ in 150 min (Table 4 entry 2; Fig 8 red curve). TMEDA and $\mathrm{N}$-methyl pyrrolidine displayed lower activity as figured out by lower yields and slower kinetics (Table 4, entries 3-4).

Table 4: Effect of the organic base for the carbonation reaction of propylene glycol to afford propylene carbonate. Reaction conditions: Propylene glycol $\left(0.5 \mathrm{mmol}\right.$ in $\left.200 \mu \mathrm{L} \mathrm{CH}_{2} \mathrm{Cl}_{2}\right)$, base $(1 \mathrm{mmol}), \mathrm{TsCl}(0.5 \mathrm{mmol})$, $25^{\circ} \mathrm{C}, 1 \mathrm{MPa}$.

\begin{tabular}{cc|cc}
\hline Entry & Base & $\begin{array}{c}\text { PG conv. } \\
(\%)^{1,2}\end{array}$ & $\begin{array}{c}\text { PC yield } \\
(\%)^{1,3}\end{array}$ \\
\hline 1 & TEA & 80 & 80 \\
2 & DIPEA & 75 & 75 \\
3 & TMEDA & 58 & 58 \\
4 & N-Methyl Pyrrolidine & ND & 45 \\
\hline
\end{tabular}

${ }^{1}$ Determined after $3 \mathrm{~h}$

${ }^{2}$ Conversion of propylene glycol calculated from ${ }^{1} \mathrm{H}$ NMR with 1,3,5-trimethoxybenzene as internal standard

${ }^{3} \mathrm{PC}$ yield calculated from ATR-IR and from ${ }^{1} \mathrm{H}$ NMR with 1,3,5-trimethoxybenzene as internal standard

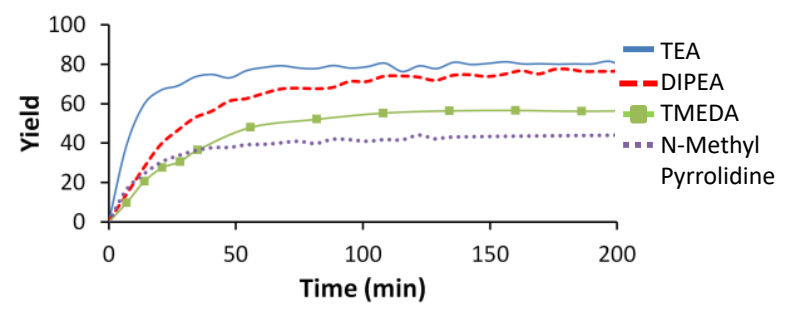

Figure 8: Yield of propylene carbonate (PC) with the reaction time for various organic bases. Reaction conditions are described in Table 4.

\subsection{Substrate scope}

Even if $\mathrm{DBU} / \mathrm{EtBr}$ and $\mathrm{TEA} / \mathrm{TsCl}$ promote the carbonation of diols under mild operative conditions, the benchmarking of their performances as well as their influence on the product selectivities has never been assessed. The coupling chemistry of different classes of alcohols (1,x-diols with $\mathrm{x}=2,3$ or $\geq 4$ ) with $\mathrm{CO}_{2}$ to afford di-, tri- and tetrasubstituted ethylene 
carbonates, (substituted) trimethylene carbonates or acyclic biscarbonated compounds (Scheme 5) was then balanced regarding both activating systems. Insights into the products yield and selectivity (linear vs cyclic carbonates) are highlighted by benchmarking the performance metrics of both dual activation systems. This study will guide the reader to select the most efficient dual system and the optimal operating conditions to drive the selective formation of the envisioned (a)cyclic carbonate.

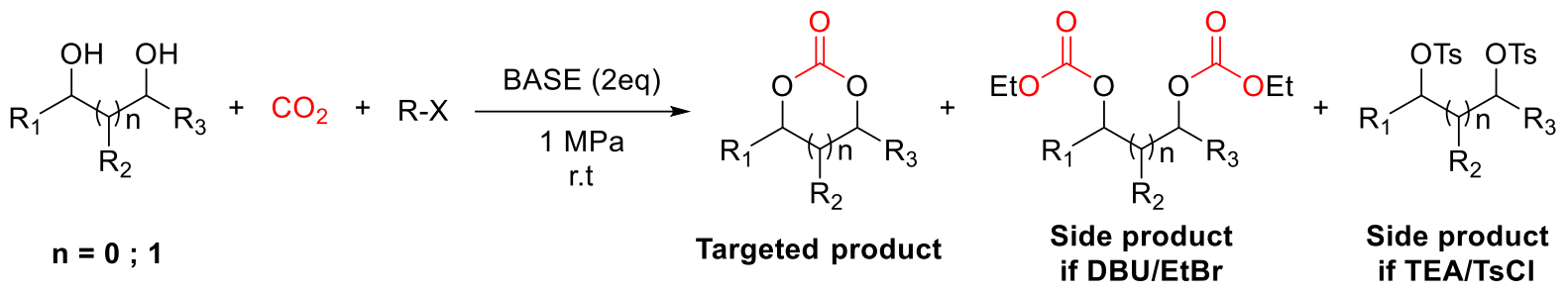

Scheme 5: Substrate scope comparison between the two dual agents $\mathrm{DBU} / \mathrm{EtBr}$ and TEA/TsCl. Side products directly depend on the method used.

\subsubsection{Selectivity for 1,2-diols substrates}

Vicinal diols were expected to give ethylene carbonates analogues as the main product due to their known stability. However, depending on the structure of the 1,2-diol, a different selectivity toward the cyclic or biscarbonated linear product was observed (Table 5, entries 14) when $\mathrm{DBU} / \mathrm{EtBr}$ was used. The carbonation of ethylene glycol (product A) afforded a mixture of biscarbonate and ethylene carbonate for $\mathrm{DBU} / \mathrm{EtBr}$ as the activating system with a low selectivity in cyclic carbonate (39\%). When TEA/TsCl was used however, the yield in cyclic carbonate was improved from $19 \%$ up to $44 \%$ with a greater selectivity of $69 \%$ (Table 5 entry 1). Side products (tosylated alcohols) were still observed at a $20 \%$ yield. When the substrate was switched to propylene glycol (PG), great selectivity toward the cyclic carbonate was observed for both systems (Table 5 entry 2). Best results were obtained with TEA/TsCl as the dual system with a $79 \%$ yield and $100 \%$ selectivity of propylene carbonate. In a similar fashion as for product A, 2,3-butanediol (product C) displayed a poor yield and selectivity toward the cyclic carbonate when DBU/EtBr was used. Yet, the dual system TEA/TsCl provides a satisfying way to obtain mainly the corresponding cyclic carbonate with a moderate yield of $46 \%$ with $100 \%$ selectivity (Table 5 entry 3 ). We believe that double carbonation occurs in the case of products $\mathrm{A}$ and $\mathrm{C}$ when $\mathrm{DBU} / \mathrm{EtBr}$ was used since both

Table 5: Substrate scope for the carbonation of diols for both dual activating systems DBU/EtBr and TEA/TsCl<smiles>[X]C(O)COC(C)CO</smiles> 


\begin{tabular}{|c|c|c|c|c|c|c|c|}
\hline \multirow[b]{2}{*}{ Entry } & \multirow[b]{2}{*}{ Substrate } & \multicolumn{3}{|c|}{ DBU/EtBr } & \multicolumn{3}{|c|}{ TEA/TsCl } \\
\hline & & $\begin{array}{c}\text { Yield cyclic } \\
\text { carbonate }^{1} \\
(\%)\end{array}$ & $\begin{array}{c}\text { Yield } \\
\text { biscarbonated }^{2} \\
(\%)\end{array}$ & $\begin{array}{l}\text { Selectivity } \\
\text { cyclic } \\
\text { carbonate }\end{array}$ & $\begin{array}{c}\text { Yield cyclic } \\
\text { carbonate }^{3} \\
(\%)\end{array}$ & $\begin{array}{c}\text { Yield } \\
\text { tosylated } \\
\text { alcohol }^{4} \\
(\%) \\
\end{array}$ & $\begin{array}{c}\text { Selectivity } \\
\text { cyclic } \\
\text { carbonate } \\
(\%)\end{array}$ \\
\hline 1 & $A$ & 19 & 29 & 39 & 44 & 20 & 69 \\
\hline 2 & $P G$ & 73 & 15 & 83 & $79(55)^{5}$ & 0 & 100 \\
\hline 3 & $\mathrm{C}$ & 20 & 27 & 42 & 46 & 0 & 100 \\
\hline 4 & $D$ & 27 & 0 & 100 & $67(50)^{5}$ & 0 & 100 \\
\hline 5 & $E$ & $75(60)^{5}$ & 0 & 100 & 55 & 20 & 73 \\
\hline 6 & $\mathrm{~F}$ & 0 & 54 & 0 & $90(60)^{5}$ & 4 & 96 \\
\hline 7 & $\mathrm{G}$ & 0 & 0 & 0 & 0 & 0 & 0 \\
\hline 8 & $\mathrm{H}$ & 17 & 31 & 35 & $64(39)^{5}$ & 12 & 84 \\
\hline 9 & 1 & 15 & 54 & 22 & $84(58)^{5}$ & 0 & 100 \\
\hline 10 & $\mathrm{~J}$ & 0 & 56 & 0 & 0 & ND & I \\
\hline 11 & $\mathrm{~K}$ & 0 & 51 & 0 & 0 & ND & I \\
\hline
\end{tabular}

${ }^{1}$ : Yield of the corresponding carbonate after $20 \mathrm{~h}$, estimated by quantitative ${ }^{1} \mathrm{H}$ NMR. Conditions: Diol (0.5 mmol); DBU (1 mmol); $\mathrm{EtBr}(1.2 \mathrm{mmol}) ; \mathrm{CH}_{2} \mathrm{Cl}_{2}(200 \mu \mathrm{L}) ; 1,3,5$-trimethoxybenzene $(0.166 \mathrm{mmol})$ as internal standard ; $1 \mathrm{MPa}$, r.t.

2: Yield of the corresponding biscarbonated compound after 20h, estimated by quantitative NMR. Conditions: Diol (0.5 mmol); DBU (1 mmol); $\operatorname{EtBr}(1.2 \mathrm{mmol}) ; \mathrm{CH}_{2} \mathrm{Cl}_{2}(200 \mu \mathrm{L}) ; 1,3,5$-trimethoxybenzene $(0.166 \mathrm{mmol})$ as internal standard ; $1 \mathrm{MPa}$, r.t.

${ }^{3}$ : Yield of the corresponding carbonate after $3 \mathrm{~h}$, estimated by quantitative NMR. Conditions: Diol (0.5 mmol); TEA (1 mmol); TsCl $(0.5 \mathrm{mmol}) ; \mathrm{CH}_{2} \mathrm{Cl}_{2}(200 \mu \mathrm{L}) ; 1$,3,5-trimethoxybenzene $(0.166 \mathrm{mmol})$ as internal standard ; 1 MPa, r.t.

4: Yield of the corresponding tosylated alcohol after 3h, estimated by quantitative NMR. Conditions: Diol (0.5 mmol); TEA (1 mmol); $\mathrm{TsCl}(0.5 \mathrm{mmol}) ; \mathrm{CH}_{2} \mathrm{Cl}_{2}(200 \mu \mathrm{L}) ;$ 1,3,5-trimethoxybenzene $(0.166 \mathrm{mmol})$ as internal standard; $1 \mathrm{MPa}$, r.t.

5: Isolated yields after purification for a couple of best results. Experiments were carried out again on a larger scale and products purified by column chromatography. See ESI for NMR spectra.

alcohol functions are equivalent due to the molecular symmetry. Moreover, small steric hindrance due to the presence of hydrogens or only one methyl must allow the double insertion of $\mathrm{CO}_{2}$. Whereas no huge differences were observed between carbonation of the primary or secondary alcohol with DBU as a base when DFT calculations were performed (see ESI 3), experimental results tend to demonstrate that non-equivalent alcohol functions favour the formation of 5 membered cyclic carbonates, as it is the case for PG. In the case of TEA, no double carbonation are expected as it was previously reported for 2,2-dimethylpropane-1,3diol with a $100 \%$ selectivity toward monocarbonated species, versus $41 \%$ toward biscarbonated species when DBU was used as a base[45]. Tetrasubstituted Pinacol (product D) was poorly converted into the corresponding cyclic carbonate (diol conversion: $27 \%$ ) with however no double carbonation (Table 5, entry 4) with DBU/EtBr activating system, due to greater steric hindrance. However, the cyclic carbonate yield was greatly improved up to 67 $\%$ when TEA/TsCl was used, with $100 \%$ selectivity toward the cyclic product. To the best of our knowledge, 4,4,5,5-tetramethyl-1,3-dioxolan-2-one was successfully synthesized from $\mathrm{CO}_{2}$ for the first time, while other attempts using the $\mathrm{CO}_{2}$ /epoxide coupling failed to obtain this product [61]. Interestingly, glycerol (product E) was selectively converted into glycerol carbonate with a yield of $75 \%$ using the dual system DBU/EtBr (Table 5, entry 5). This alkylating agent/organobase activating system surpasses the performance of TEA/TsCl that 
only afforded glycerol carbonate with a yield of $55 \%$ with concomitant formation of $20 \%$ of tosylated alcohols as side products, highlighting the substrate dependence for each method and the differences in selectivity. These differences are even more highlighted when trans1,2-cyclohexanediol (product F) was used as the substrate. In this case, cyclisation is disfavoured compared to other vicinal diols due to the trans configuration. Interestingly, the cyclic carbonate could still be synthetized in excellent yield (90\%, Table 5 entry 6) and selectivity close to $100 \%$ with TEA/TsCl but not in the case of $\mathrm{DBU} / \mathrm{EtBr}$. For the latter, biscarbonation is favoured and biscarbonated compounds were selectively synthetized in good yield (54\%, Table 5 entry 6). Unfortunately, pyrocatechol (product G) could not be converted into any carbonates (Table 5 entry 7 ).

\subsubsection{Selectivity for 1,3 -diols substrates}

When the DBU/EtBr protocol was applied to the carbonation of 1,3 diols such as 1,3butanediol (product $\mathrm{H}$ ) and hexylene glycol (product I), linear biscarbonates were found as the major products (yield $=31$ and $54 \%$, respectively) (Table 5, entries 8 and 9). The formation of the biscarbonated products was favoured due to a larger spacer between both alcohol moieties, in accordance to previous studies[45,46]. Experimentally, 6-membered cyclic carbonates were formed in good yields with great selectivities (Table 5, entries 8 and 9) using $\mathrm{TEA} / \mathrm{TsCl}$. Thus, one can tailor the selectivity toward the biscarbonated compounds or substituted trimethylene carbonate by opting for the adequate dual system. This study is particularly relevant as 6-membered cyclic carbonates are modular building blocks for polymer synthesis via ring-opening polymerization[19].

\subsubsection{Selectivity for $1, x$-diols substrates $(x \geq 4)$}

Coupling $\mathrm{CO}_{2}$ with diols with a larger spacer is expected to favour the carbonation of both alcohol moieties with the formation of acyclic biscarbonates. These compounds are indeed exclusively obtained from 1,4-butanediol or isosorbide in moderate yields (Table 5, entries 10 and 11) with no formation of the 7-membered cyclic carbonates. No cyclic products were detected in the case of the TEA/TsCl system. A small fraction of dimers and trimers were detected indicating the system is still reactive for this class of diols.

In order to deeply understand the selectivity between cyclisation or biscarbonation depending on the nature of the diol when DBU is used as the base, DFT calculations were performed at the $M 062 X / 6-311 g(d, p)$ level. For each diol, the activation barriers of the alkylation and biscarbonation steps were compared. For both calculations, the starting point was the optimized geometry of monocarbonated species (product of step 1, see Scheme 4 and Fig. 3). Firstly, biscarbonation was not considered in the reaction pathway with PG as the diol, since its activation barrier is $3.3 \mathrm{kcal} / \mathrm{mol}$ higher than the activation barrier of alkylation (Table 6, entry 1 ), which explains the low percentage of biscarbonated products ( $\leq 15 \%)$. Moreover, all other activation barriers for the conversion of PG into propylene carbonate are lower than $23.3 \mathrm{kcal} / \mathrm{mol}$ (Fig. 4). For ethylene glycol (Table 6, entry 2), both activation barriers are of similar magnitude, indicating that both pathways would compete, which is consistent with 
experimental results (Table 5, entry 1 ). As the length of the spacer between both alcohol functions is increased, the activation barrier for biscarbonation decreases whereas alkylation barrier remains around $20 \mathrm{kcal} / \mathrm{mol}$ (Table 6, entries 3, 4 and 5). These results support the experimental data collected in Table 5 where 1,3 diols yielded a mixture of (substituted) trimethylene carbonates and biscarbonated products, whereas 1,4-butanediol and Isosorbide only yielded the biscarbonated product.

Table 6: DFT calculation (M062X/6-311g(d,p)) for the comparison between monocarbonation followed by alkylation versus carbonation of both alcohol moieties (biscarbonation).

(20.0

1: Gibbs Free Energy activation were calculated by the difference of Gibbs Free Energy of the transition state and the corresponding optimized reaction intermediates. The optimized structures of the transition states are reported at the end of the ESI.

\section{Conclusion}

In this work, deep investigations of a model reaction for the coupling of propylene glycol and $\mathrm{CO}_{2}$ under mild conditions $\left(25{ }^{\circ} \mathrm{C} ; 1 \mathrm{MPa}\right.$ ) promoted by two different metal-free dual activating systems led to a fine understanding of these carbonation reactions. The protocol was optimized thanks to mechanistic and kinetic studies of various parameters reported for the first time, such as influence of the pressure, temperature, solvent and nature of the alkyl halide. Most importantly, extension to other diols using both synthetic pathways provided a powerful guide for the reader to choose the best dual activating system regarding the desired product. If cyclic carbonates are highly desired, $\mathrm{TEA} / \mathrm{TsCl}$ gives the most interesting results with fast kinetics to afford selectively 5- and 6- membered carbonates. However, DBU/EtBr must be used for the selective synthesis of glycerol carbonate from glycerol. The latter is also effective to tailor selectivity toward biscarbonated compounds when $1, x$ diols $(x \geq 3)$ are used 
as substrates, as for instance to obtain biscarbonated isosorbide. DFT calculations supported the experimental results obtained. This benchmarking highlights the versatility of these organic based dual activating systems and demonstrates the substrate dependency of such carbonation reactions. Perspectives to improve the efficiency of the process would be to recycle these activating systems which are currently used in stoichiometric amounts. To this aim, polymer-supported organic (super)bases could be an alternative way to improve the recyclability of the system.

\section{Acknowledgements}

The authors of Liège thank the "Region Wallonne" in the frame of the CO2Green, and Flycoat projects, the "Belgian Science Policy" in the frame of the "Interuniversity Attraction Poles Programme (IAP VII/5) - Functional Supramolecular Systems" and the "Fonds National pour la Recherche Scientifique" (F.R.S.-FNRS) for financial supports. The PhD fellowship of A. Brege was co-funded by the "Conseil Regional d'Aquitaine" and the "University of LIEGE" through the international doctoral school program EJD-Funmat. We also thank computational facilities provided by the MCIA (Mesocentre de Calcul Intensif Aquitain) of the University of Bordeaux financed by the "Conseil Regional d'Aquitaine".

\section{REFERENCES}

[1] T.F. Stocker, Intergovernmental Panel on Climate Change 2013: Physical Science Basis, Contribution of Working Group I to the Fifth Assessment Report of the Intergovernmental Panel on Climate Change, Cambridge University Press (2013).

[2] R.B. Jackson, C. Le Quéré, R.M. Andrew, J.G. Canadell, G.P. Peters, J. Roy, L. Wu, Warning signs for stabilizing global CO2 emissions, Environ. Res. Lett. 12(11) (2017) 110202.

[3] M. Aresta, A. Dibenedetto, Utilisation of $\mathrm{CO} 2$ as a chemical feedstock: opportunities and challenges, Dalton Trans (28) (2007) 2975-92.

[4] P.J.A. Kenis, A. Dibenedetto, T. Zhang, Carbon Dioxide Utilization Coming of Age, Chemphyschem 18(22) (2017) 3091-3093.

[5] M. Aresta, Carbon Dioxide as Chemical Feedstock, WILEY-VCH (2010).

[6] T. Sakakura, J. C. Choi, H. Yasuda, Transformation of Carbon Dioxide, Chem. Rev. 107 (2007) 23652387.

[7] C. Maeda, Y. Miyazaki, T. Ema, Recent progress in catalytic conversions of carbon dioxide, Catal. Sci. Tech. 4(6) (2014) 1482-1497.

[8] G. Fiorani, W. Guo, A.W. Kleij, Sustainable conversion of carbon dioxide: the advent of organocatalysis, Green Chem. 17(3) (2015) 1375-1389.

[9] A. Tortajada, F. Juliá-Hernández, M. Börjesson, T. Moragas, R. Martin, Transition-Metal-Catalyzed Carboxylation Reactions with Carbon Dioxide, Angew. Chem. Int. Ed. 57(49) (2018) 15948-15982.

[10] Y. Cao, X. He, N. Wang, H.-R. Li, L.-N. He, Photochemical and Electrochemical Carbon Dioxide Utilization with Organic Compounds, Chin. J. Chem . 36(7) (2018) 644-659. 
[11] J. Artz, T.E. Müller, K. Thenert, J. Kleinekorte, R. Meys, A. Sternberg, A. Bardow, W. Leitner, Sustainable Conversion of Carbon Dioxide: An Integrated Review of Catalysis and Life Cycle Assessment, Chem. Rev. 118(2) (2018) 434-504.

[12] N.A. Tappe, R.M. Reich, V. D'Elia, F.E. Kühn, Current advances in the catalytic conversion of carbon dioxide by molecular catalysts: an update, Dalton Trans. 47(38) (2018) 13281-13313.

[13] N. Yadav, F. Seidi, D. Crespy, V. D'Elia, Polymers Based on Cyclic Carbonates as Trait d'Union Between Polymer Chemistry and Sustainable CO2 Utilization, ChemSuschem 12(4) (2019) 724-754.

[14] A.J. Kamphuis, F. Picchioni, P.P. Pescarmona, CO2-fixation into cyclic and polymeric carbonates: principles and applications, Green Chem. 21(3) (2019) 406-448.

[15] S. Gennen, B. Grignard, T. Tassaing, C. Jerome, C. Detrembleur, CO2 -Sourced alpha-Alkylidene Cyclic Carbonates: A Step Forward in the Quest for Functional Regioregular Poly(urethane)s and Poly(carbonate)s, Angew Chem Int Ed Engl 56(35) (2017) 10394-10398.

[16] A.-A.G. Shaikh, S. Sivaram, Organic Carbonates, Chem. Rev. 96(3) (1996) 951-976.

[17] L. Maisonneuve, O. Lamarzelle, E. Rix, E. Grau, H. Cramail, Isocyanate-Free Routes to

Polyurethanes and Poly(hydroxy Urethane)s, Chem. Rev. 115(22) (2015) 12407-39.

[18] B. Grignard, J.M. Thomassin, S. Gennen, L. Poussard, L. Bonnaud, J.M. Raquez, P. Dubois, M.P. Tran, C.B. Park, C. Jerome, C. Detrembleur, CO2-blown microcellular non-isocyanate polyurethane (NIPU) foams: from bio- and CO2-sourced monomers to potentially thermal insulating materials, Green Chem. 18(7) (2016) 2206-2215.

[19] G. Rokicki, Aliphatic cyclic carbonates and spiroorthocarbonates as monomers, Prog. Polym. Sci. 25(2) (2000) 259-342.

[20] B. Grignard, S. Gennen, C. Jérôme, A.W. Kleij, C. Detrembleur, Advances in the use of CO2 as a renewable feedstock for the synthesis of polymers, Chem. Soc. Rev. 48(16) (2019) 4466-4514.

[21] M. Alves, B. Grignard, R. Mereau, C. Jerome, T. Tassaing, C. Detrembleur, Organocatalyzed coupling of carbon dioxide with epoxides for the synthesis of cyclic carbonates: catalyst design and mechanistic studies, Catal. Sci. Tech. 7(13) (2017) 2651-2684.

[22] S.B. Lawrenson, R. Arav, M. North, The greening of peptide synthesis, Green Chem. 19(7) (2017) 1685-1691.

[23] W. Clegg, R.W. Harrington, M. North, F. Pizzato, P. Villuendas, Cyclic carbonates as sustainable solvents for proline-catalysed aldol reactions, Tetrahedron: Asymmetry 21(9) (2010) 1262-1271.

[24] X.D. Lang, L.N. He, Green Catalytic Process for Cyclic Carbonate Synthesis from Carbon Dioxide under Mild Conditions, Chem Rec 16(3) (2016) 1337-52.

[25] M. North, R. Pasquale, C. Young, Synthesis of cyclic carbonates from epoxides and $\mathrm{CO} 2$, Green Chem. 12(9) (2010) 1514-1539.

[26] M. Alves, B. Grignard, A. Boyaval, R. Méreau, J. De Winter, P. Gerbaux, C. Detrembleur, T. Tassaing, C. Jérôme, Organocatalytic Coupling of CO2 with Oxetane, ChemSusChem 10(6) (2017) 1128-1138.

[27] P. Goodrich, H.Q.N. Gunaratne, J. Jacquemin, L. Jin, Y. Lei, K.R. Seddon, Sustainable Cyclic Carbonate Production, Utilizing Carbon Dioxide and Azolate lonic Liquids, ACS Sustainable Chem. Eng. 5(7) (2017) 5635-5641.

[28] P. Goodrich, H.Q.N. Gunaratne, L. Jin, Y. Lei, K.R. Seddon, Carbon Dioxide Utilisation for the Synthesis of Unsymmetrical Dialkyl and Cyclic Carbonates Promoted by Basic lonic Liquids, Aust. J. Chem. 71(3) (2018) 181-185.

[29] F.D. Bobbink, A.P. van Muyden, P.J. Dyson, En route to CO2-containing renewable materials: catalytic synthesis of polycarbonates and non-isocyanate polyhydroxyurethanes derived from cyclic carbonates, Chem. Commun. 55(10) (2019) 1360-1373.

[30] J. Rintjema, W. Guo, E. Martin, E.C. Escudero-Adan, A.W. Kleij, Highly Chemoselective Catalytic Coupling of Substituted Oxetanes and Carbon Dioxide, ChemPubSoc 21(30) (2015) 10754-62.

[31] C. Martín, G. Fiorani, A.W. Kleij, Recent Advances in the Catalytic Preparation of Cyclic Organic Carbonates, ACS Catal. 5(2) (2015) 1353-1370. 
[32] A. Boyaval, R. Méreau, B. Grignard, C. Detrembleur, C. Jerome, T. Tassaing, Organocatalytic Coupling of CO2 with a Propargylic Alcohol: A Comprehensive Mechanistic Study, ChemSusChem 10(6) (2017) 1241-1248.

[33] J. Rintjema, A.W. Kleij, Substrate-Assisted Carbon Dioxide Activation as a Versatile Approach for Heterocyclic Synthesis, Synthesis 48(22) (2016) 3863-3878.

[34] Q.-W. Song, L.-N. He, Transition Metal-Promoted CO2Conversion under Mild Reaction Conditions, Advances in $\mathrm{CO} 2$ Capture, Sequestration, and Conversion, American Chemical Society2015, pp. 47-70.

[35] R. Méreau, B. Grignard, A. Boyaval, C. Detrembleur, C. Jerome, T. Tassaing, Tetrabutylammonium Salts: Cheap Catalysts for the Facile and Selective Synthesis of $\alpha$-Alkylidene Cyclic Carbonates from Carbon Dioxide and Alkynols, ChemCatChem 10(5) (2018) 956-960.

[36] B. Grignard, C. Ngassamtounzoua, S. Gennen, B. Gilbert, R. Méreau, C. Jerome, T. Tassaing, C. Detrembleur, Boosting the Catalytic Performance of Organic Salts for the Fast and Selective Synthesis of $\alpha$-Alkylidene Cyclic Carbonates from Carbon Dioxide and Propargylic Alcohols, ChemCatChem 10(12) (2018) 2584-2592.

[37] S. Dabral, B. Bayarmagnai, M. Hermsen, J. SchießI, V. Mormul, A.S.K. Hashmi, T. Schaub, SilverCatalyzed Carboxylative Cyclization of Primary Propargyl Alcohols with CO2, Org. Lett. 21(5) (2019) 1422-1425.

[38] N. Kindermann, T. Jose, A.W. Kleij, Synthesis of Carbonates from Alcohols and CO2, Top Curr Chem (Cham) 375(1) (2017) 15.

[39] M. Tamura, M. Honda, Y. Nakagawa, K. Tomishige, Direct conversion of CO2 with diols, aminoalcohols and diamines to cyclic carbonates, cyclic carbamates and cyclic ureas using heterogeneous catalysts, J. Chem. Technol. Biotechnol 89(1) (2014) 19-33.

[40] A. Hosseinian, S. Farshbaf, R. Mohammadi, A. Monfared, E. Vessally, Advancements in sixmembered cyclic carbonate (1,3-dioxan-2-one) synthesis utilizing carbon dioxide as a C1 source, RSC Adv. 8(32) (2018) 17976-17988.

[41] F.D. Bobbink, W. Gruszka, M. Hulla, S. Das, P.J. Dyson, Synthesis of cyclic carbonates from diols and CO2 catalyzed by carbenes, Chem. Commun. 52(71) (2016) 10787-10790.

[42] M. Honda, M. Tamura, Y. Nakagawa, K. Tomishige, Catalytic CO2 conversion to organic carbonates with alcohols in combination with dehydration system, Catal. Sci. Technol. 4(9) (2014) 2830-2845.

[43] M. Honda, M. Tamura, K. Nakao, K. Suzuki, Y. Nakagawa, K. Tomishige, Direct Cyclic Carbonate Synthesis from $\mathrm{CO} 2$ and Diol over Carboxylation/Hydration Cascade Catalyst of $\mathrm{CeO} 2$ with 2Cyanopyridine, ACS Catal. 4(6) (2014) 1893-1896.

[44] M.R. Reithofer, Y.N. Sum, Y. Zhang, Synthesis of cyclic carbonates with carbon dioxide and cesium carbonate, Green Chem. 15(8) (2013) 2086-2090.

[45] T.M. McGuire, E.M. López-Vidal, G.L. Gregory, A. Buchard, Synthesis of 5- to 8-membered cyclic carbonates from diols and $\mathrm{CO} 2$ : A one-step, atmospheric pressure and ambient temperature procedure, J. CO2 Util. 27 (2018) 283-288.

[46] G.L. Gregory, M. Ulmann, A. Buchard, Synthesis of 6-membered cyclic carbonates from 1,3-diols and low CO2 pressure: a novel mild strategy to replace phosgene reagents, RSC Adv. 5(49) (2015) 39404-39408.

[47] T. Kitamura, Y. Inoue, T. Maeda, J. Oyamada, Convenient synthesis of ethylene carbonates from carbon dioxide and 1,2-diols at atmospheric pressure of carbon dioxide, Synth. Commun. 46(1) (2015) 39-45.

[48] Z. Chen, N. Hadjichristidis, X. Feng, Y. Gnanou, Cs2CO3-promoted polycondensation of $\mathrm{CO} 2$ with diols and dihalides for the synthesis of miscellaneous polycarbonates, Polym. Chem. 7(30) (2016) 4944-4952.

[49] D. Pati, X. Feng, N. Hadjichristidis, Y. Gnanou, Hydrophobic, Hydrophilic, and Amphiphilic Polyglycocarbonates with Linear and Macrocyclic Architectures from Bicyclic Glycocarbonates Derived from CO2 and Glucoside, Macromolecules 50(4) (2017) 1362-1370. 
[50] D. Pati, X. Feng, N. Hadjichristidis, Y. Gnanou, $\mathrm{CO} 2$ as versatile carbonation agent of glycosides: Synthesis of 5- and 6-membered cyclic glycocarbonates and investigation of their ring-opening, J. CO2 Util. 24 (2018) 564-571.

[51] Y.N. Lim, C. Lee, H.-Y. Jang, Metal-Free Synthesis of Cyclic and Acyclic Carbonates from CO2and Alcohols, Eur. J. Org. Chem. 2014(9) (2014) 1823-1826.

[52] D.J. Heldebrant, P.G. Jessop, C.A. Thomas, C.A. Eckert, C.L. Liotta, The Reaction of 1,8Diazabicyclo[5.4.0] undec-7-ene (DBU) with Carbon Dioxide, J. Org. Chem. 70(13) (2005) 5335-5338.

[53] K.N. Onwukamike, T. Tassaing, S. Grelier, E. Grau, H. Cramail, M.A.R. Meier, Detailed Understanding of the DBU/CO2 Switchable Solvent System for Cellulose Solubilization and Derivatization, ACS Sustainable Chem. Eng. 6(1) (2018) 1496-1503.

[54] J. Wang, Z. Xue, C. Yan, Z. Li, T. Mu, Fine regulation of cellulose dissolution and regeneration by low pressure CO2 in DMSO/organic base: dissolution behavior and mechanism, PCCP 18(48) (2016) 32772-32779.

[55] A.-H. Liu, R. Ma, C. Song, Z.-Z. Yang, A. Yu, Y. Cai, L.-N. He, Y.-N. Zhao, B. Yu, Q.-W. Song, Equimolar $\mathrm{CO} 2$ Capture by N-Substituted Amino Acid Salts and Subsequent Conversion, Angew. Chem. Int. Ed. 51(45) (2012) 11306-11310.

[56] M. Stievano, N. Elvassore, High-pressure density and vapor-liquid equilibrium for the binary systems carbon dioxide-ethanol, carbon dioxide-acetone and carbon dioxide-dichloromethane, J. Supercrit. Fluids 33(1) (2005) 7-14.

[57] K. Shirono, T. Morimatsu, F. Takemura, Gas Solubilities (CO2, O2, Ar, N2, H2, and He) in Liquid Chlorinated Methanes, J. Chem. Eng. Data 53(8) (2008) 1867-1871.

[58] R.A. Nyquist, W.J. Potts, Infrared absorptions characteristic of organic carbonate derivatives and related compounds, Spectrochim. Acta 17(7) (1961) 679-697.

[59] A.C. Galvão, A.Z. Francesconi, Methane and carbon dioxide solubility in 1,2-propylene glycol at temperatures ranging from 303 to $423 \mathrm{~K}$ and pressures up to $12 \mathrm{MPa}$, Fluid Phase Equilib. 289(2)

(2010) 185-190.

[60] K.C. Lethesh, S.N. Shah, M.I.A. Mutalib, Synthesis, Characterization, and Thermophysical Properties of 1,8-Diazobicyclo[5.4.0]undec-7-ene Based Thiocyanate lonic Liquids, J. Chem. Eng. Data 59(6) (2014) 1788-1795.

[61] M. Adolph, T.A. Zevaco, C. Altesleben, O. Walter, E. Dinjus, New cobalt, iron and chromium catalysts based on easy-to-handle N4-chelating ligands for the coupling reaction of epoxides with CO2, Dalton Trans 43(8) (2014) 3285-96.

\title{
SUPPLEMENTARY INFORMATION for
}

\section{The coupling of $\mathrm{CO}_{2}$ with diols promoted by organic dual systems: towards products divergence via benchmarking of the performance metrics}

\author{
A. Brege ${ }^{a, b}$, R. Méreau ${ }^{a}, K^{2}$ McGehee ${ }^{a}$, B. Grignard ${ }^{b}$, C. Detrembleur ${ }^{b}$, C. Jerome ${ }^{b}, T$. \\ Tassaing $^{\mathrm{a}^{*}}$ \\ ${ }^{a}$ Institut des Sciences Moléculaires, UMR 5255 CNRS-Université de Bordeaux, 351, Cours de la \\ Libération, F-33405 Talence Cedex, France
}


${ }^{\mathrm{b}}$ Center for Education and Research on Macromolecules (CERM), CESAM Research Unit, University of Liege, Allée de la Chimie, B6a, 4000 Liège (Belgium).

\section{ESI 1 : Evidences of the trimolecular interaction between $\mathrm{CO}_{2}$, DBU and PG}

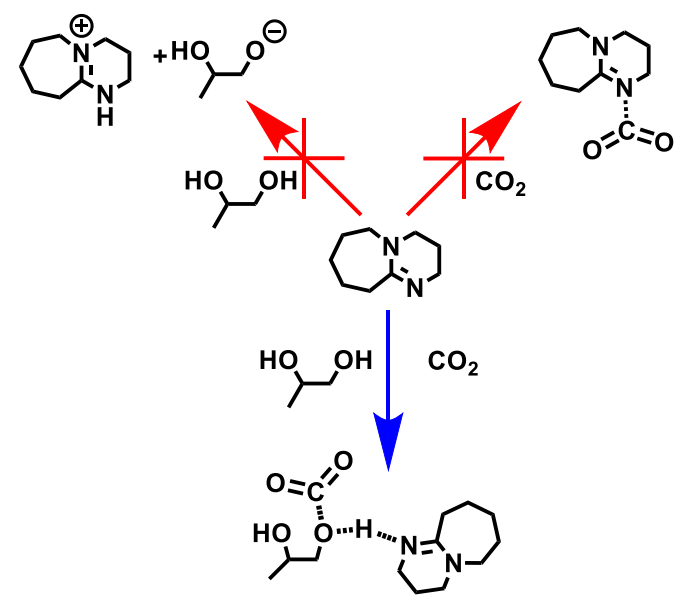

Scheme S1: Trimolecular reaction between PG, $\mathrm{DBU}$ and $\mathrm{CO}_{2}$. No adduct or special interaction is observed with only two species at the same time.

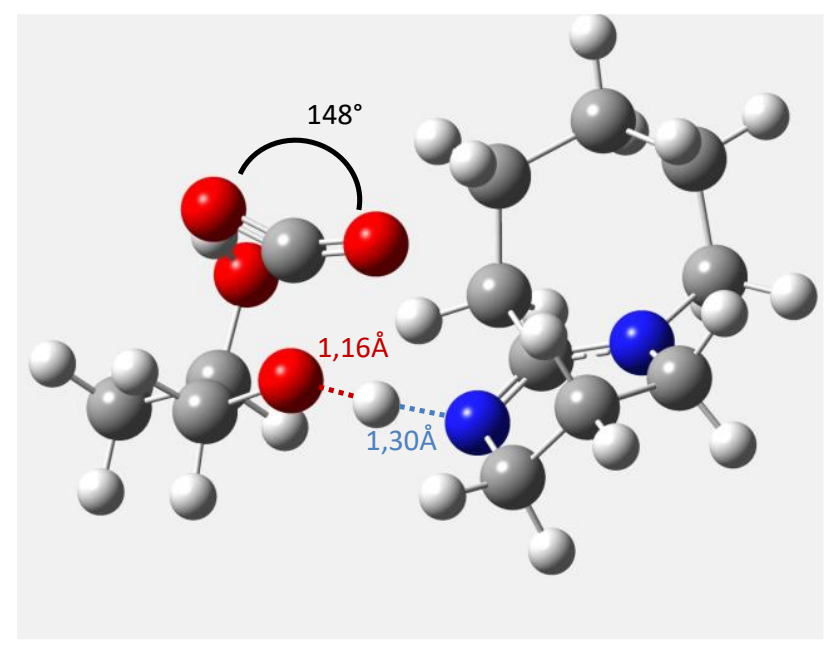

Figure S1: Molecular modelling of the transition state TS1 with trimolecular interaction between PG, DBU and $\mathrm{CO}_{2}$. $\mathrm{Hydrogen}$ bonding between PG and $\mathrm{DBU}$, and angular deformation of $\mathrm{CO}_{2}$ occur at the same time. 


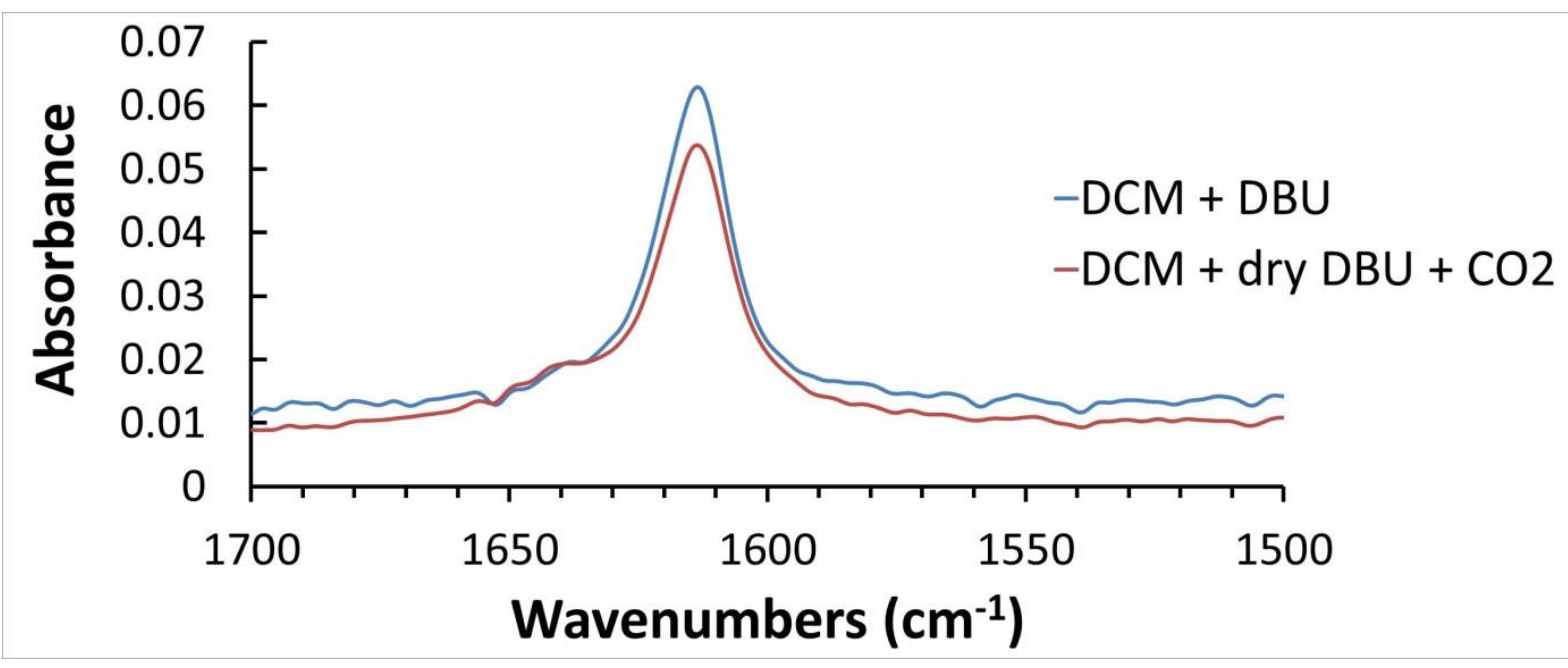

Figure S2: ATR-IR spectra of the $\mathrm{DBU} / \mathrm{CO}_{2}$ system in dichloromethane (DCM). A pressure of $1 \mathrm{MPa} \mathrm{CO}_{2}$ was applied. When $\mathrm{DBU}$ was dried, no interaction or adduct between $\mathrm{DBU}$ and $\mathrm{CO}_{2}$ can be observed. In the presence of water, $\mathrm{DBUH}^{+} / \mathrm{HCO}_{3}{ }^{-}$salts are formed.

\section{ESI 2: Molar attenuation coefficient determination of propylene carbonate}

\section{for quantitative ATR-IR measurements}

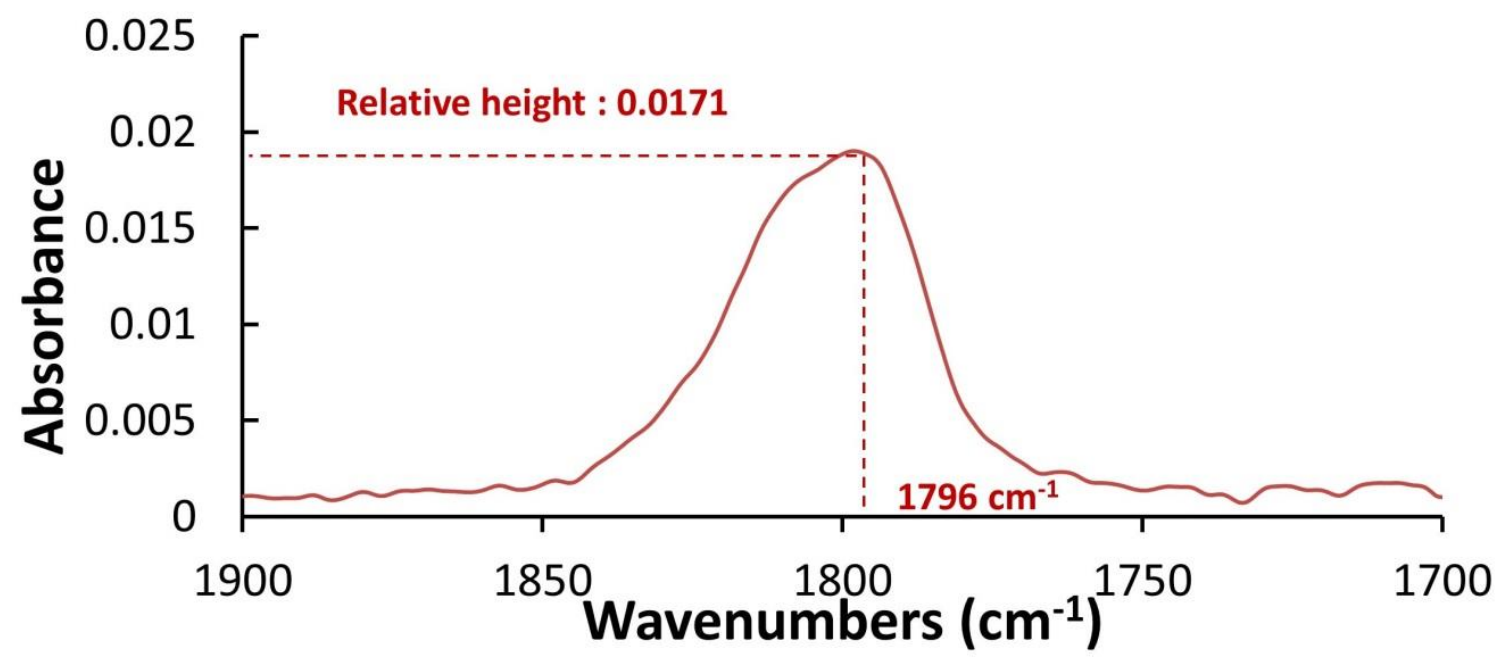

Figure S3: Experimental determination of the molar attenuation coefficient of propylene carbonate by ATR-IR : Propylene carbonate $(0.5 \mathrm{mmol} ; 42.3 \mu \mathrm{L}) ; \mathrm{DBU}(1 \mathrm{mmol} ; 149.2 \mu \mathrm{L}) ; \mathrm{BuBr}(1.2 \mathrm{mmol} ; 130 \mu \mathrm{L}) ; \mathrm{CH}_{2} \mathrm{Cl}_{2}:(200 \mu \mathrm{L})$.

Table S1: Results obtained for the determination of $\varepsilon^{*} \mid$ of propylene carbonate. Concentration of propylene carbonate (PC) in all experiments was calculated through Beer-Lambert law using a value of $\varepsilon^{*} \mid$ for pure propylene carbonate $(0.0192 \mathrm{~mL} / \mathrm{mmol})$ since no significant difference was observed for other molecular environments.

\begin{tabular}{|l|c|c|c|}
\hline Molecular species & Carbonate concentration & Peak height & $\varepsilon^{*}(\mathrm{~mL} / \mathrm{mmol})$ \\
\hline $\mathrm{PC} ; \mathrm{DBU} ; \mathrm{BuBr} ; \mathrm{CH}_{2} \mathrm{Cl}_{2}$ & $0.96 \mathrm{~mol} / \mathrm{L}$ & 0.0171 & 0.0178 \\
\hline $\mathrm{PC}$ & $11.85 \mathrm{~mol} / \mathrm{L}$ & 0.227 & 0.0192 \\
\hline
\end{tabular}




\section{ESI $3:{ }^{1} \mathrm{H}$ NMR characterization of the crude reaction mixture}
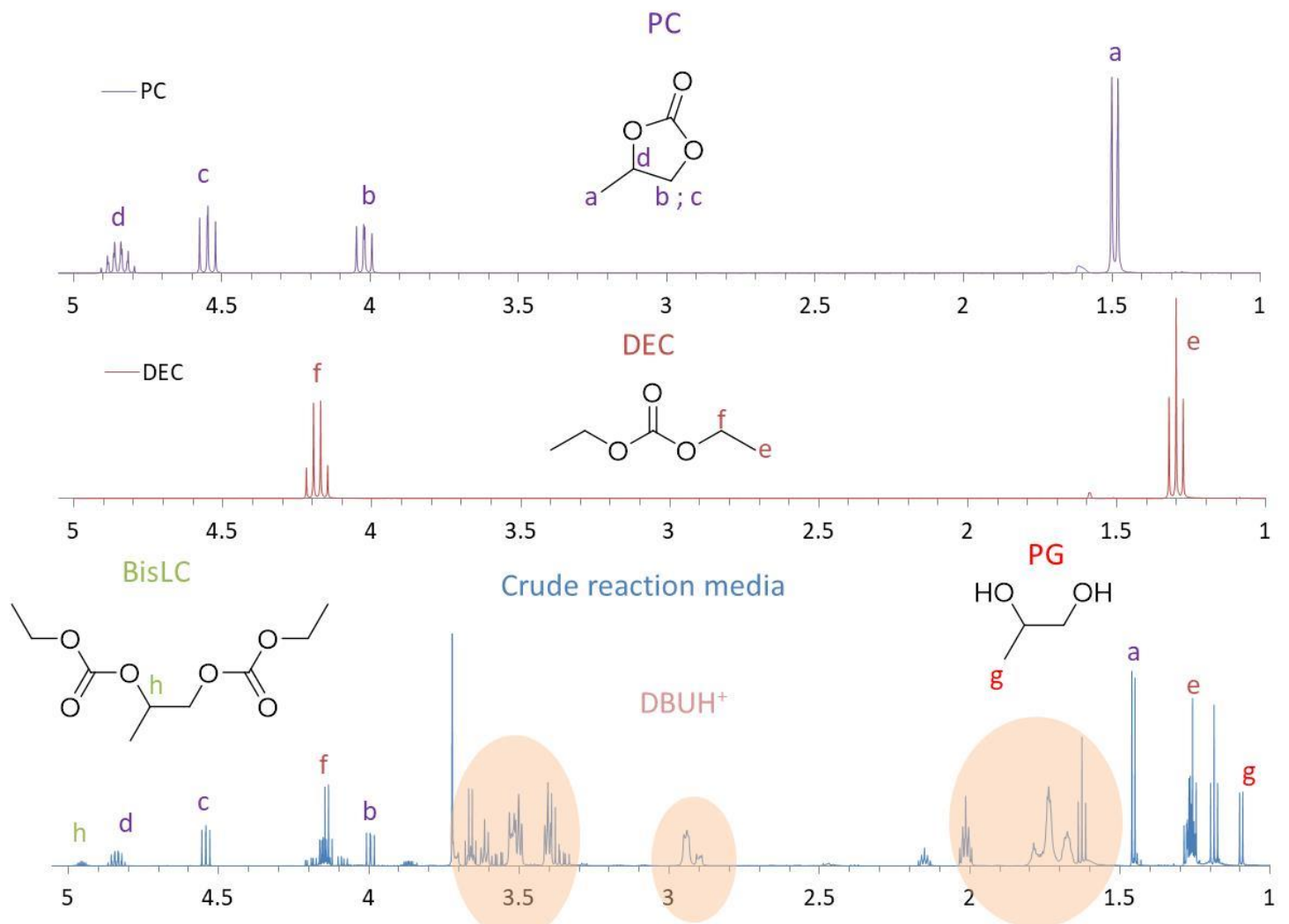

Figure S4: ${ }^{1} \mathrm{H}$ NMR $\left(300 \mathrm{MHz}, \mathrm{CDCl}_{3}\right)$ of (a) propylene carbonate $(\mathrm{PC})$, (b) diethyl carbonate (DEC) and (c) the crude reaction mixture (sample entry 1 , Table 1 )

Chemical shifts $\left(\mathrm{CDCl}_{3}\right)$ :

PC:

a: $1.48-1.42$ ppm (3H, d, $\left.\mathrm{CH}_{3} \mathrm{CHO}\right) ; \mathrm{b}: 4.02-3.95 \mathrm{ppm}(1 \mathrm{H}, \mathrm{dd}, \mathrm{CHHO}) ; \mathrm{c}: 4.57-4.50 \mathrm{ppm}(1 \mathrm{H}, \mathrm{dd}$, $\mathrm{CHHO}) ; \mathrm{d}: 4.9-4.77 \mathrm{ppm}(1 \mathrm{H}, \mathrm{m}, \mathrm{MeCHO})$

DEC:

e: $1.27-1.24$ ppm (6H, t, $\left.\mathrm{CH}_{3} \mathrm{CH}_{2}\right) ;$ f: $4.16-4.12 \mathrm{ppm}\left(4 \mathrm{H}, \mathrm{q}, \mathrm{CH}_{3} \mathrm{CH}_{2}\right)$

PG:

g: $1.11-1.09 \mathrm{ppm}\left(3 \mathrm{H}, \mathrm{d}, \mathrm{CH}_{3} \mathrm{CHOH}\right)$

BisLC:

h: $4.98-4.93 \mathrm{ppm}\left(1 \mathrm{H}, \mathrm{m}, \mathrm{CH}_{3} \mathrm{CHO}\right)$ 


\section{ESI 4 : DFT discrimination of (R) and (S) configurations and of primary and}

\section{secondary alcohol reactivities of PG.}

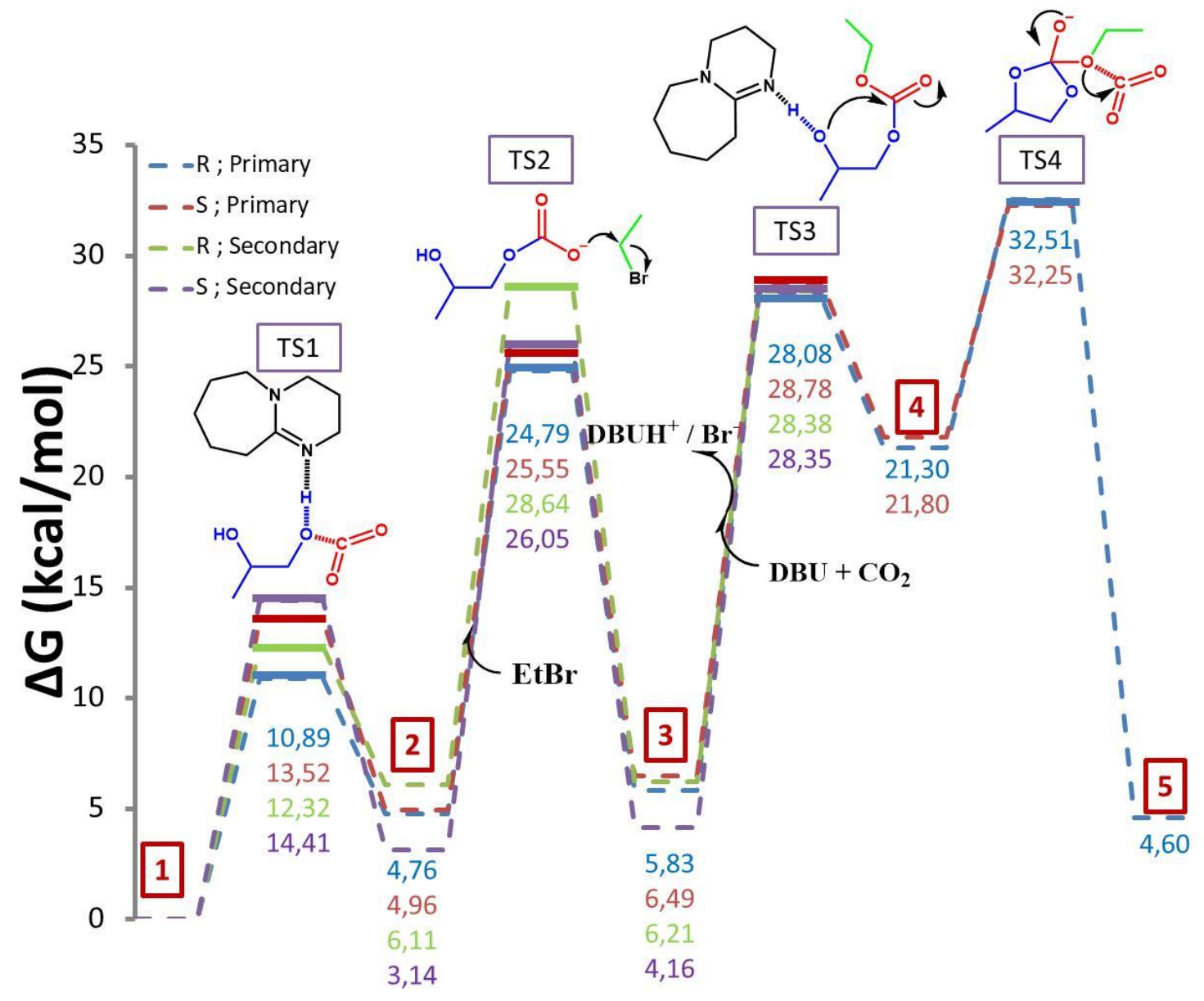

Figure S5: DFT computed pathway $(M 062 X / 6-311 g(d, p))$ of model reaction as depicted in Scheme 4. All pathways were considered for the monocarbonation of propylene glycol: carbonation on the primary or secondary alcohol moiety, with either (R) or (S) stereochemistry. Red numbers correspond to optimized reaction intermediates shown in Scheme 4 (Van Der Waals interactions were accounted). Transition states (TS) were optimized using the same molecular species as in the intermediates. The optimized structures of the intermediates and transition states for the reaction path calculated with the (R) primary alcohol are reported at the end of the ESI. 


\section{ESI 5 : Comparison between quantitative ATR-IR and quantitative ${ }^{1} \mathrm{H}$ NMR}

All yields were determined by quantitative ${ }^{1} \mathrm{H}$ NMR using 1,3,5-trimethoxybenzene (TMB) as internal standard, except for the synthesis of propylene carbonate where the yield was determined by both ${ }^{1} \mathrm{H}$ quantitative NMR and ATR-IR. A known mass of TMB ( 0.333 equivalent) was added to the reaction mixture before the introduction of $\mathrm{CO}_{2}$. Here are presented ${ }^{1} \mathrm{H}$ NMR spectrum and ATR-IR spectrum of the same sample at the end of reaction time to compare the yields obtained and confirm both methods work as quantitative methods. Attribution of peaks is detailed in ESI 3.

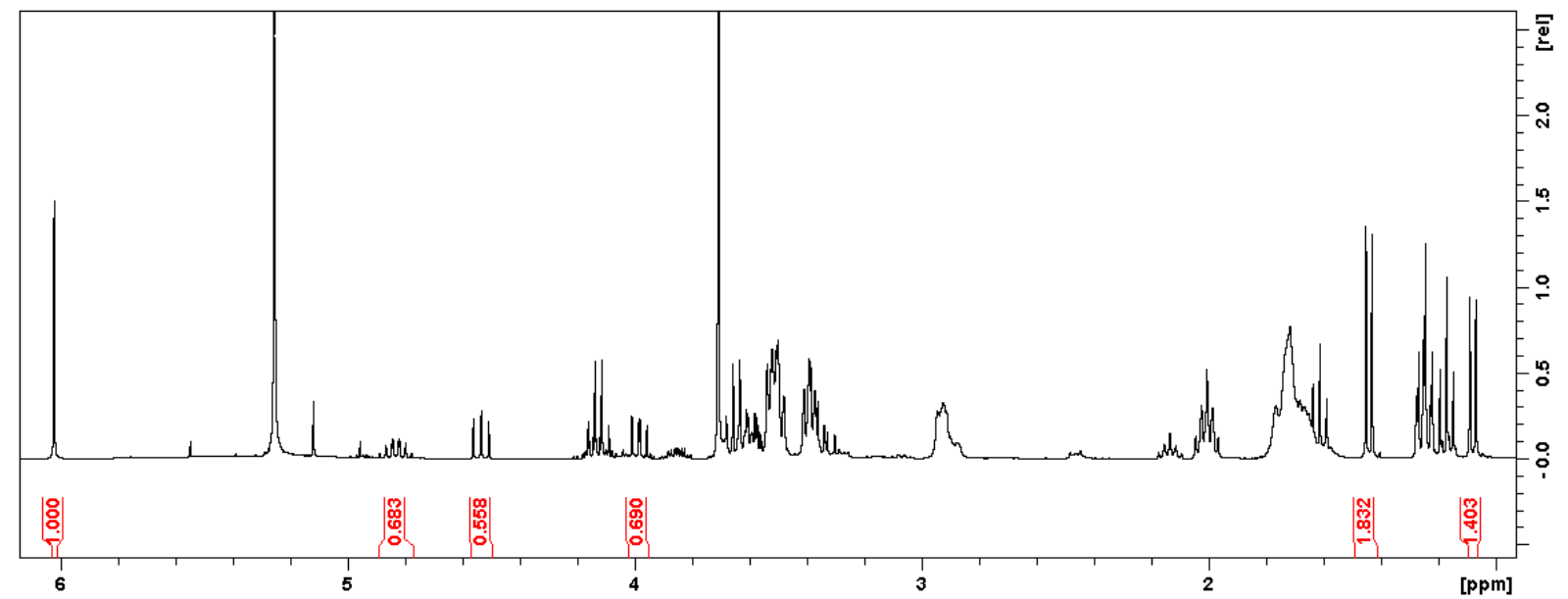

Figure S9: ${ }^{1} \mathrm{H}$ NMR spectrum of model reaction in $\mathrm{CDCl}_{3}$ (Scheme 2) after $20 \mathrm{~h}$ for the synthesis of Propylene carbonate. Propylene glycol $(0.5 \mathrm{mmol} ; 36.7 \mu \mathrm{L})$; DBU $(1 \mathrm{mmol} ; 149.2 \mu \mathrm{L}) ; \mathrm{EtBr}(1.2 \mathrm{mmol} ; 89.4 \mu \mathrm{L}) ; \mathrm{CH}_{2} \mathrm{Cl}_{2}(200 \mu \mathrm{L}) ; 1,3,5-$ trimethoxybenzene $(0.162 \mathrm{mmol} ; 27.22 \mathrm{mg})$ as internal standard. $50 \mu \mathrm{L}$ of the reaction mixture are mixed with $600 \mu \mathrm{L} \mathrm{CDCl} 3$ to perform ${ }^{1} \mathrm{H}$ NMR analysis.

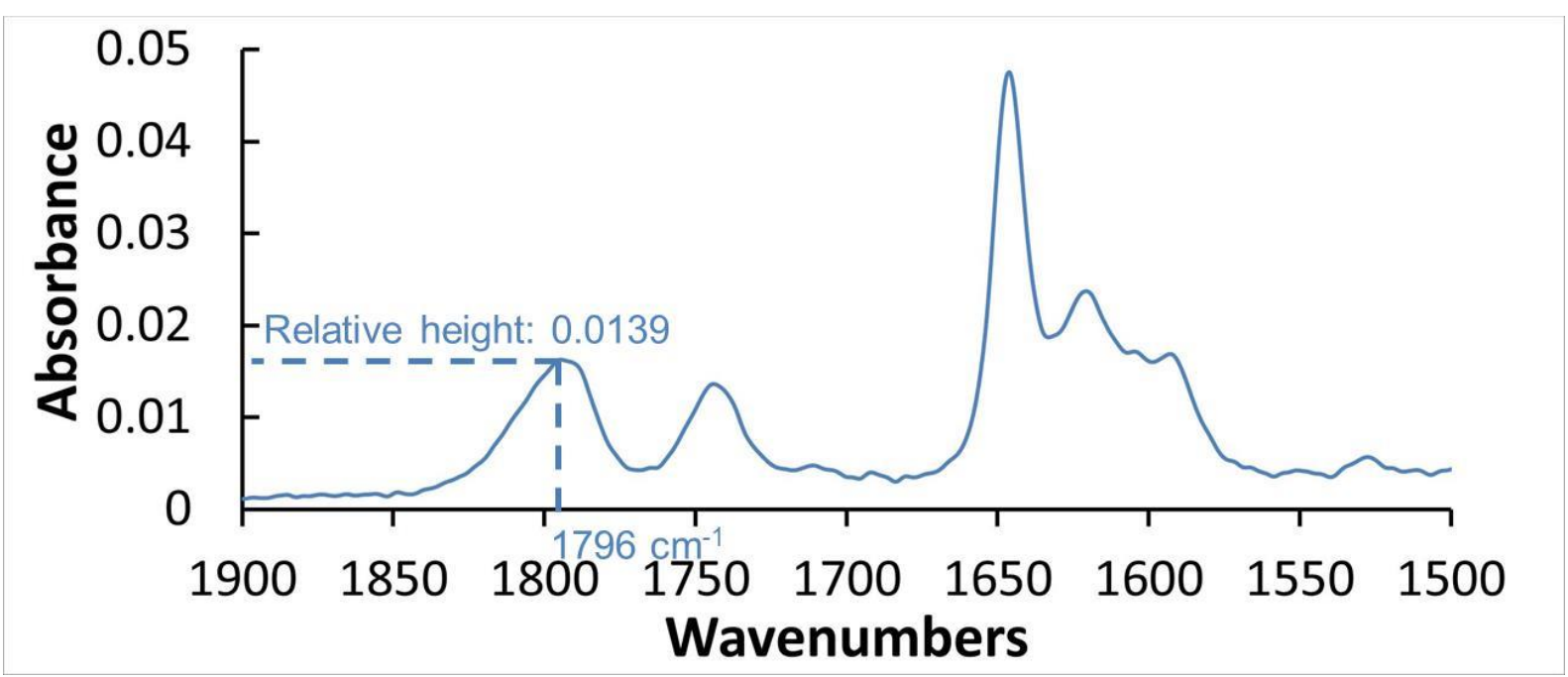

Figure S10: ATR-IR spectra of model reaction (same sample that for ${ }^{1} \mathrm{H}$ NMR spectrum, Fig. S9).

- Yield obtained from ${ }^{1} \mathrm{H}$ NMR analysis :

Propylene carbonate: $\delta: 4.9-4.77(1 \mathrm{H}, \mathrm{m}, \mathrm{MeCHO}), 4.57-4.50(1 \mathrm{H}, \mathrm{dd}, \mathrm{CH} H \mathrm{O}), 4.02-3.95(1 \mathrm{H}, \mathrm{dd}$, $\mathrm{CHHO}), 1.48-1.42\left(3 \mathrm{H}, \mathrm{d}, \mathrm{CH}_{3} \mathrm{CHO}\right)$. 
Propylene glycol: $\delta: 3.91-3.8(1 \mathrm{H}, \mathrm{m}, \mathrm{MeCHOH}), 3.63-3.55(1 \mathrm{H}, \mathrm{m}, \mathrm{CHHOH}), 3.42-3.2(1 \mathrm{H}, \mathrm{m}, \mathrm{CH} H \mathrm{H}), 1.10$ $-1.06\left(3 \mathrm{H}, \mathrm{d}, \mathrm{CH}_{3} \mathrm{CHOH}\right)$

TMB: $\delta: 6.02(3 \mathrm{H}, \mathrm{ArH}), 3.71\left(9 \mathrm{H}, \mathrm{OCH}_{3}\right)$

Proton signals of propylene carbonate were integrated with aromatic protons signal of TMB $(3 \mathrm{H})$ as reference (integration value of 1 ). As TMB was introduced with a known mass ( 0.333 equivalent of propylene glycol), one can calculate the exact mole number of propylene carbonate.

$$
n(P C)=\frac{\sum_{i} \frac{\int_{i} P C}{N_{H}^{i}}}{i} * 3 * n_{T M B}
$$

$n(P C):$ Mole number of propylene carbonate

$\int_{i} P C$ : integration value of signal " $i$ " relative to propylene carbonate

$N_{H}^{i}$ : number of hydrogen taken into account for signal "i"

$n_{T M B}:$ mole number of TMB initially introduced in the reaction media

Yield obtained from Fig. 12 is of $\mathbf{6 2} \%$.

- Yield obtained from ATR-IR analysis :

Propylene carbonate: $\mathrm{v}(\mathrm{C}=0): 1796 \mathrm{~cm}^{-1}$

As we calculated the value of $\varepsilon^{*} \mid$ for propylene carbonate (see ESI 5), one can calculate the concentration of propylene carbonate in the reaction media using Beer-Lambert law with the absorbance at $1796 \mathrm{~cm}^{-1}$.

Yield obtained from Fig. 13 is of $69 \%$.

Both methods lead to the same yield with only small differences attributed to experimental factors. 
ESI 6 : Evidence of the $\mathrm{DBUH}^{+} / \mathrm{RCO}_{3}{ }^{-}$salt precipitation at $4 \mathrm{MPa}$

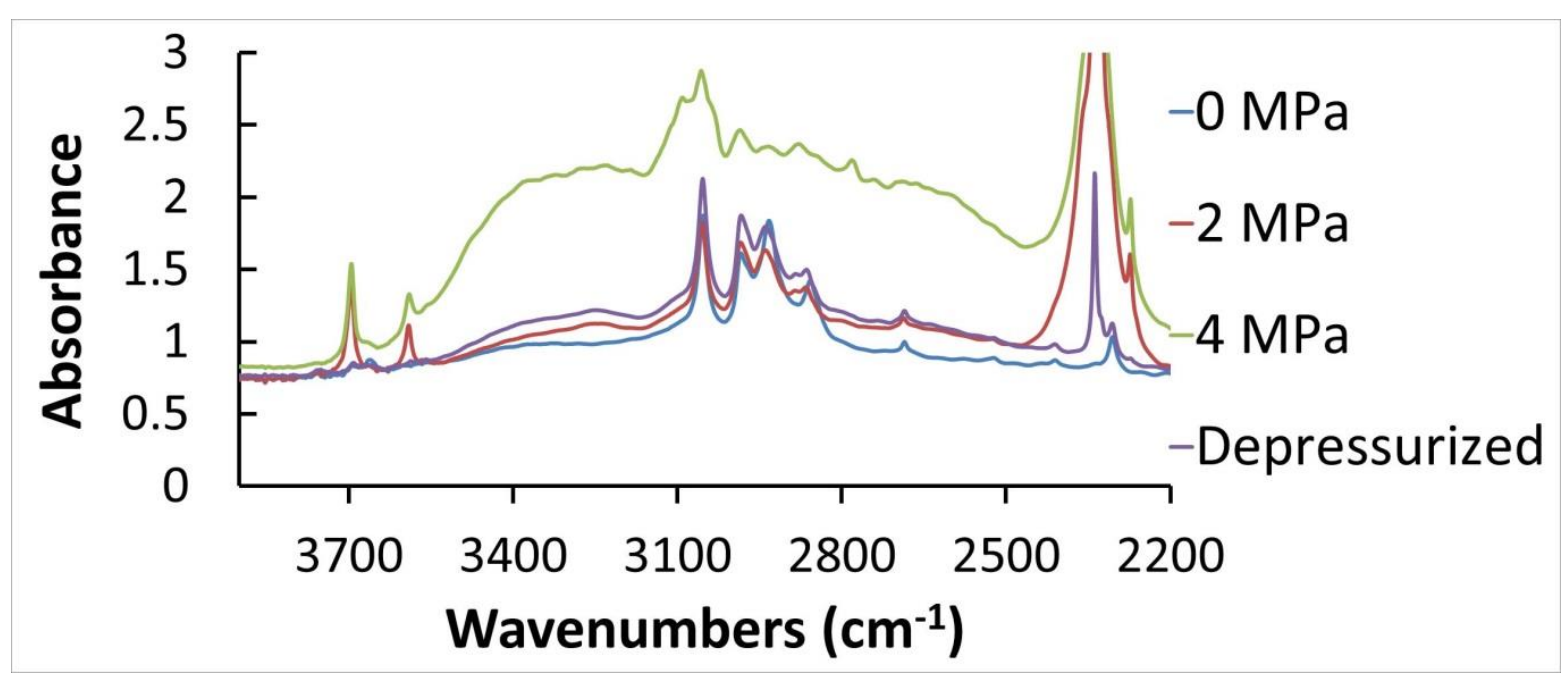

Figure S6: FT-IR (transmission) spectra collected at the equilibrium over different pressure. Purple curve was collected after depressurizing the cell at $4 \mathrm{MPa}$. Conditions: PG $(0.67 \mathrm{mmol} ; 49.2 \mu \mathrm{L}), \mathrm{DBU}(0.67 \mathrm{mmol} ; 100 \mu \mathrm{L}), \mathrm{CH}_{2} \mathrm{Cl}_{2}(850 \mu \mathrm{L})$

As the system is under pressure, carbonation of the alcohol moiety occurs. Around $4 \mathrm{MPa}$, large absorption band between $2400 \mathrm{~cm}^{-1}$ and $3500 \mathrm{~cm}^{-1}$ appears, characteristic of the formation of solid organic salts (here $\mathrm{RCO}_{3}{ }^{-} / \mathrm{DBUH}^{+}$) that interferes with the infrared beam as it deposits on the FT-IR cell window. When the system is depressurized, FT-IR profile is nearly fully recovered from the initial state, indicating organic salts are well solubilized in dichloromethane. 
ESI 7 : Evidences of the DBU quaternization with alkylating agents R-X

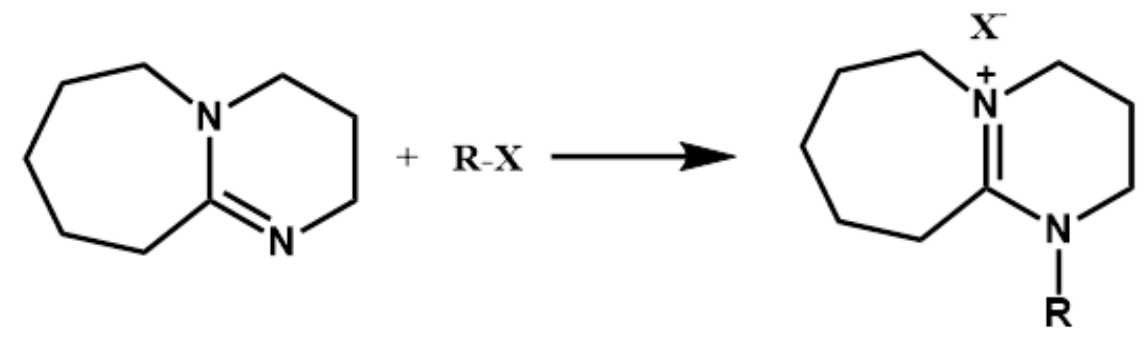

Scheme S2: Side reaction between DBU and alkyl halide (R-X): formation of ionic liquid.

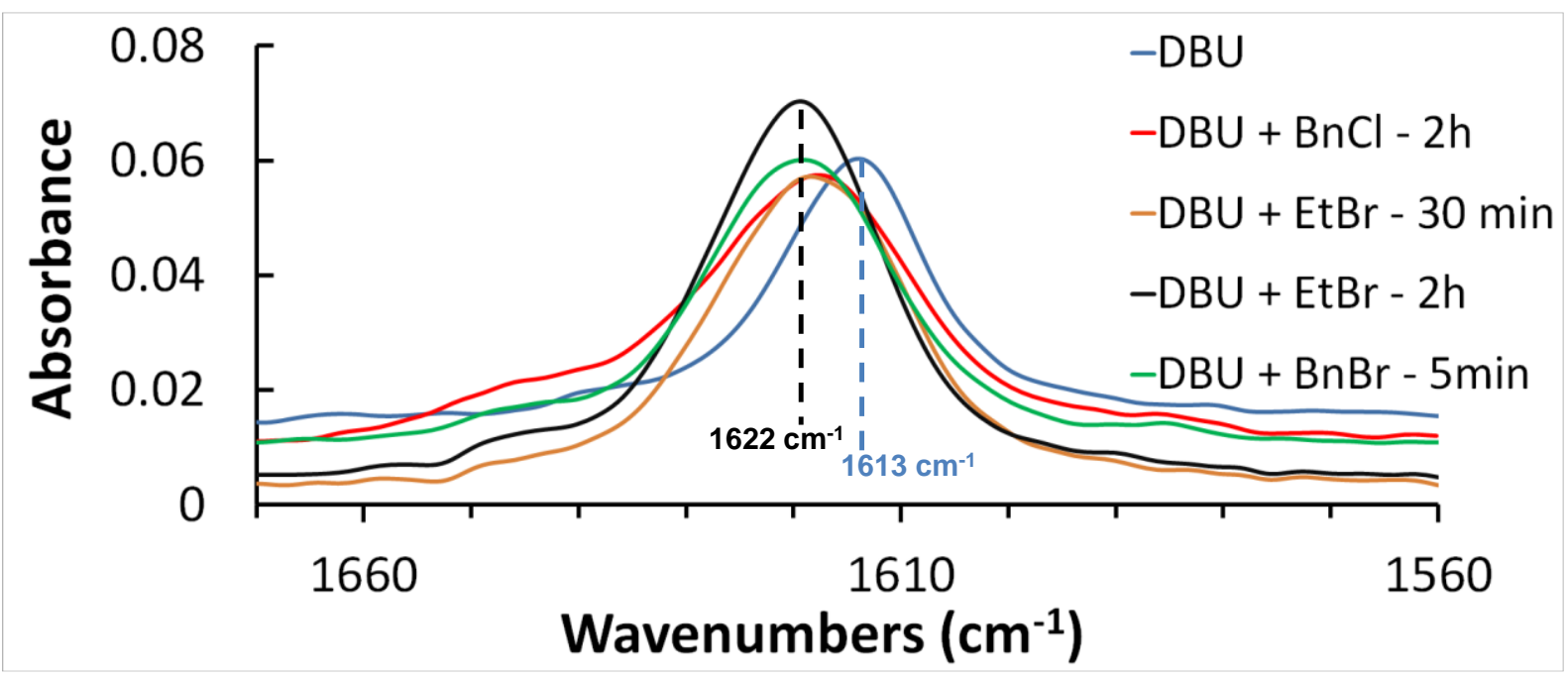

Figure S7 : ATR-IR spectra of the $\mathrm{DBU} / \mathrm{BnCl}, \mathrm{DBU} / \mathrm{BnBr}$ and $\mathrm{DBU} / \mathrm{EtBr}$ systems over time. DBU absorption band is shifted from $1613 \mathrm{~cm}^{-1}$ to $1622 \mathrm{~cm}^{-1}$ while alkylation occurs. Depending on the reactivity of $\mathrm{R}-\mathrm{X}$, reaction time varies greatly $(5 \mathrm{~min}$ for $\mathrm{BnBr}$, several hours for $\mathrm{BnCl}$ ).

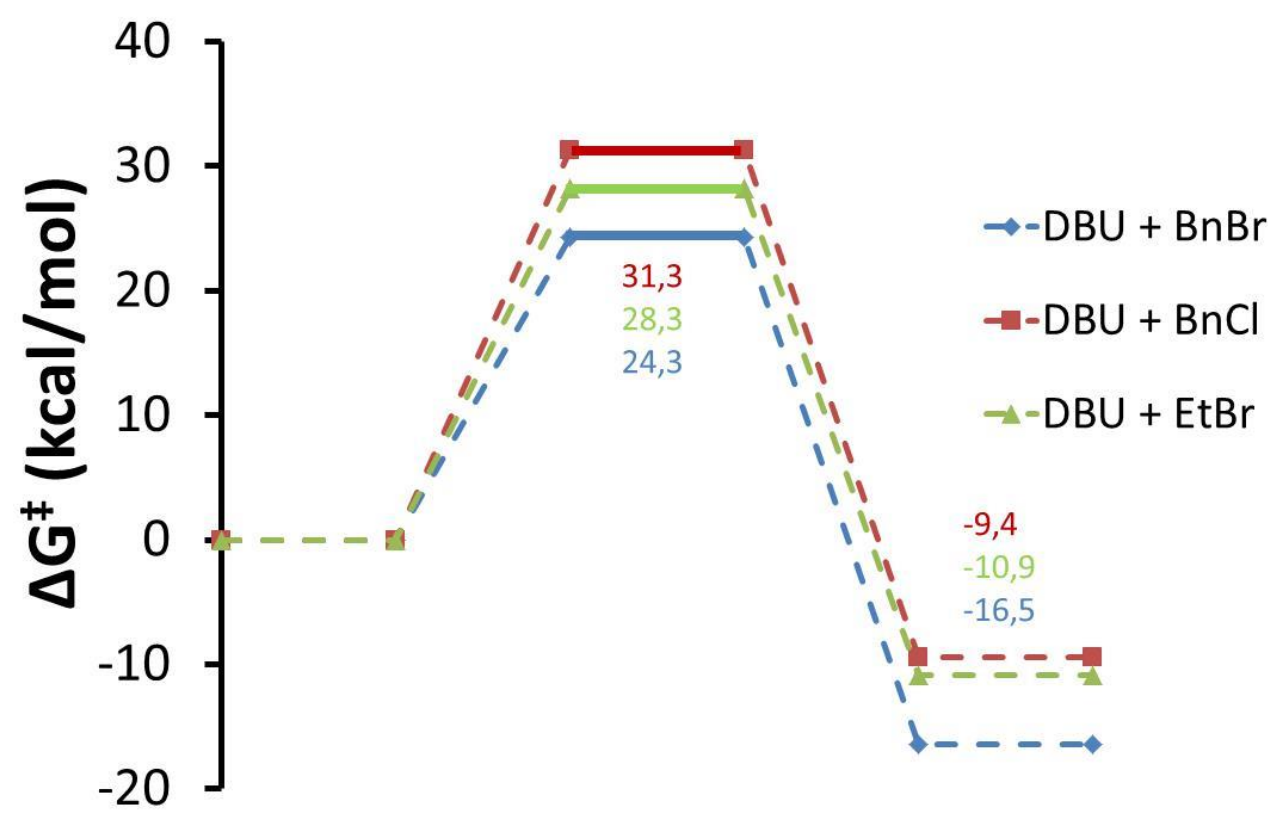

Figure S8 : DFT computed pathway $(M 062 X / 6-311 g(d, p))$ of side reaction depicted in Scheme S2. 
ESI 8: In-situ ATR-IR monitoring of the carbonation reaction of PG to afford PC

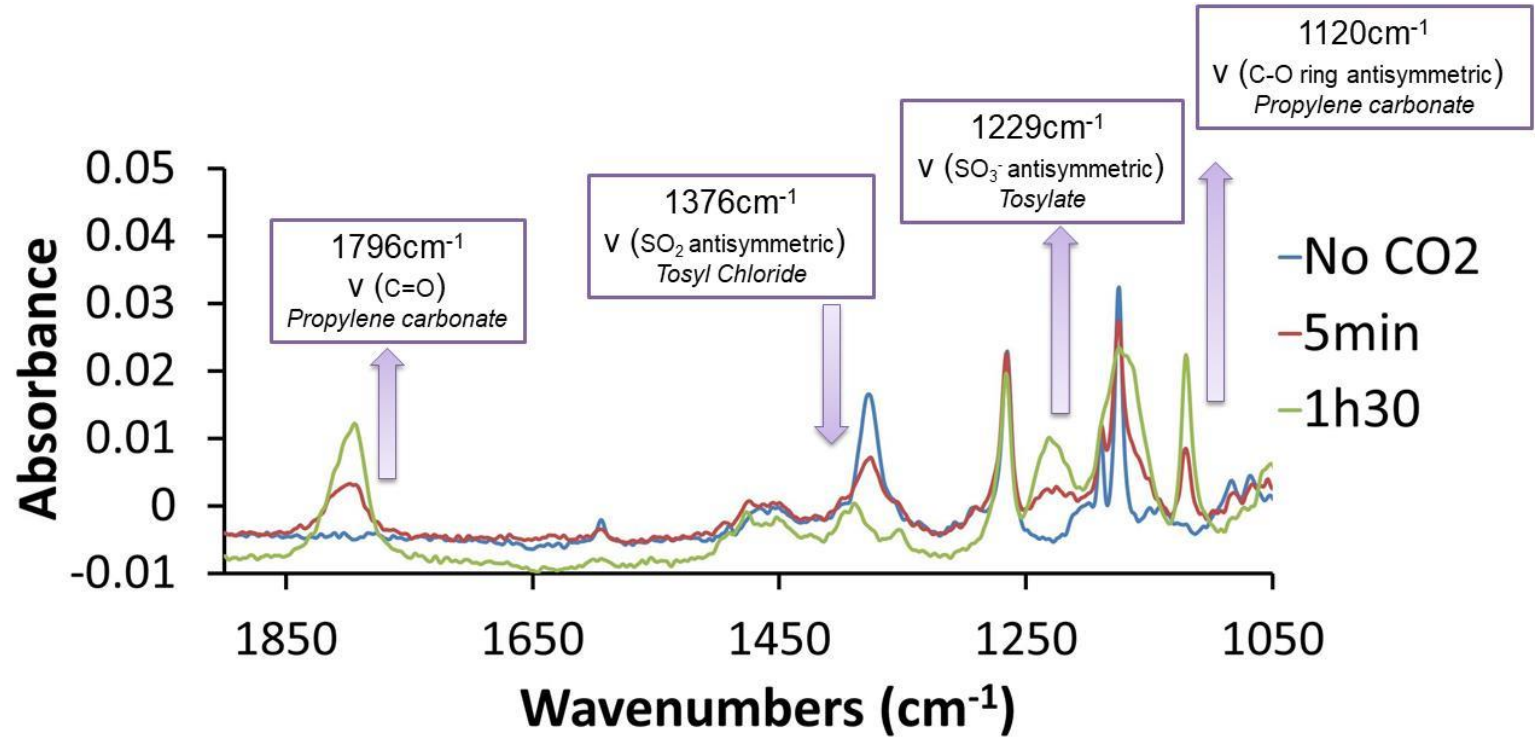

Figure S11: Monitoring of the model reaction between PG and $\mathrm{CO} 2$ promoted by a dual TEA/TsCl system using ATR-IR spectroscopy. Conditions: PG (0.5 mmol); TEA (1 mmol); TsCl $(0.5 \mathrm{mmol}) ; \mathrm{CH}_{2} \mathrm{Cl}_{2}(200 \mu \mathrm{L}) ; 1 \mathrm{MPa} ; 25^{\circ} \mathrm{C}$

Identification of product formation and reactant consumption could confirm the mechanism already proposed in the literature ${ }^{1}$

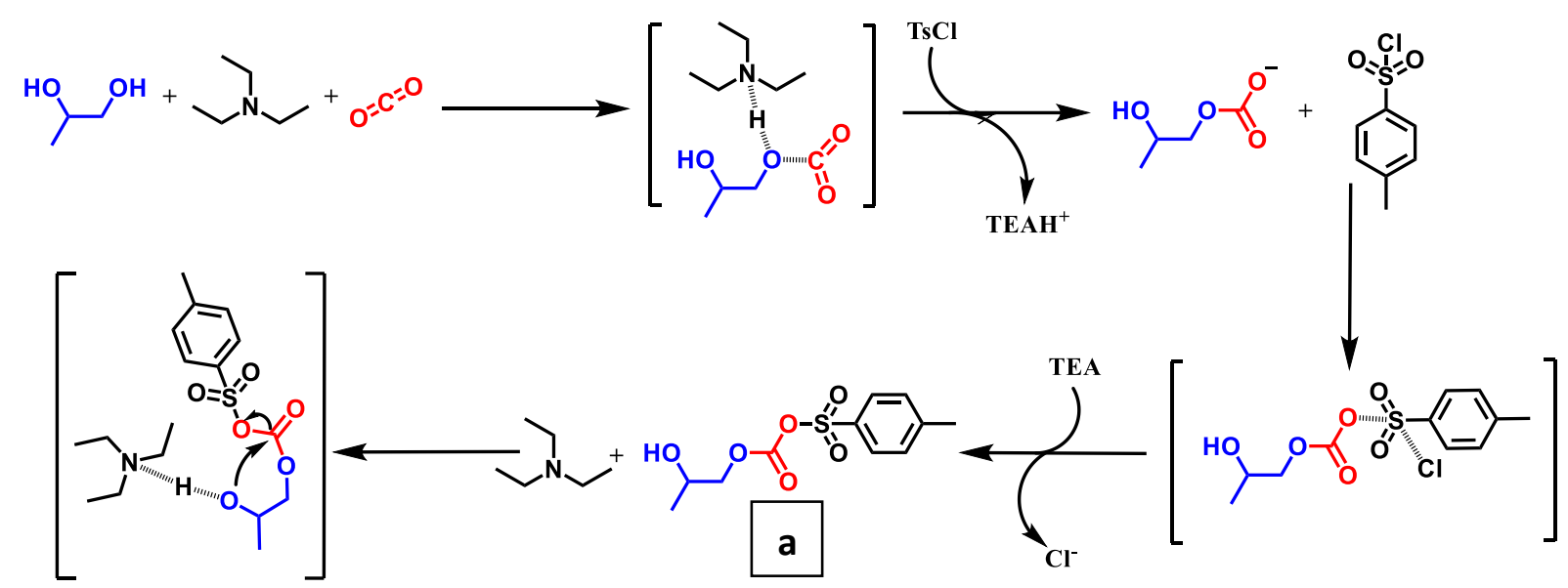

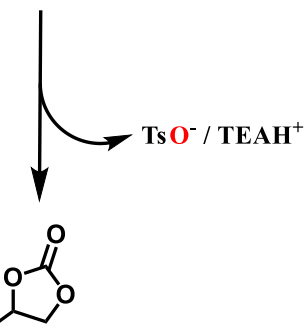

Scheme S3 : Mechanism proposal for the formation of propylene carbonate from PG, inspired from Buchard et $a l^{1}$. The presence of a was not shown by ATR-IR experiments but was proposed regarding preliminaries DFT calculations. 


\section{Characterization of organic carbonates}

4-Methyl-1,3-dioxolan-2-one : The product was isolated as a colourless oil, $2.136 \mathrm{~g}$ (isolated yield 55 \%). ${ }^{1} \mathrm{H}$ NMR $\left(400 \mathrm{MHz}, \mathrm{CDCl}_{3}\right) \delta(\mathrm{ppm}): 4.82-4.90(\mathrm{~m}, 1 \mathrm{H}), 4.55(\mathrm{dd}, J=7.8 \mathrm{~Hz}, J=8.3 \mathrm{~Hz}, 1 \mathrm{H}), 4.02$ (dd, $J=7.4 \mathrm{~Hz}, J=8.3 \mathrm{~Hz}, 1 \mathrm{H}), 1.49(\mathrm{~d}, J=6.2 \mathrm{~Hz}, 3 \mathrm{H}$ ).

${ }^{13} \mathrm{C} \mathrm{NMR}\left(400 \mathrm{MHz}, \mathrm{CDCl}_{3}\right) \delta$ (ppm): 155.0, 73. 5, 70.6, 19.2<smiles>CC1COC(=O)O1</smiles>

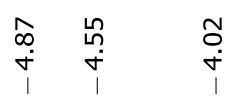
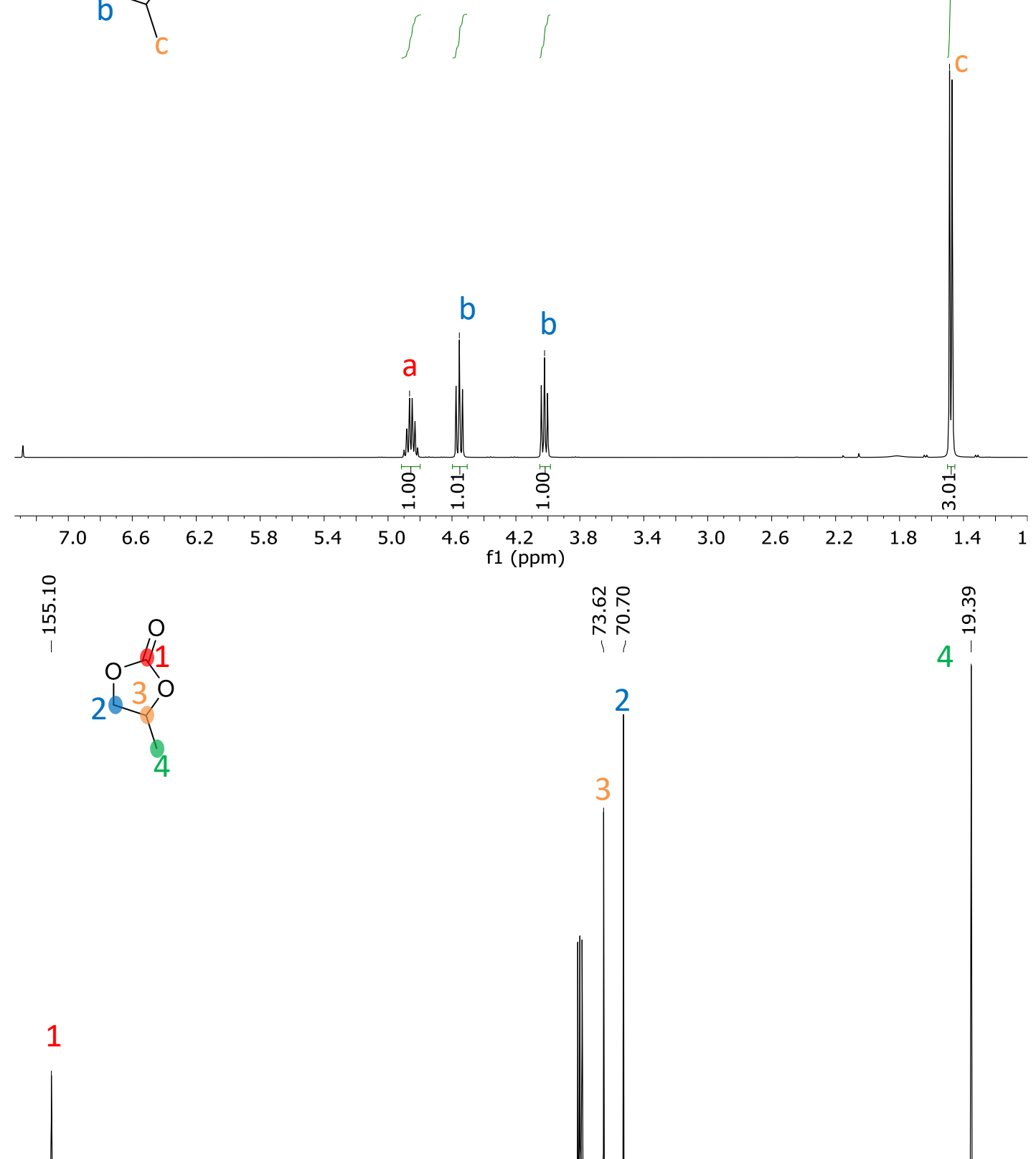

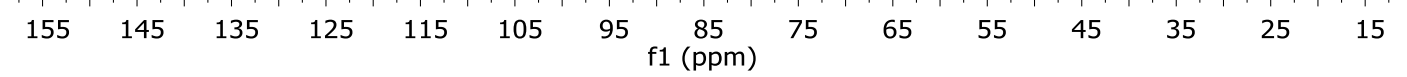


4,4,5,5-Tetramethyl-1,3-Dioxolan-2-one : The product was isolated as a white solid, $1.2976 \mathrm{~g}$ (isolated yield $50 \%$ ). ${ }^{1} \mathrm{H}$ NMR (400 MHz, CDCl3) $\delta$ (ppm): $1.40(\mathrm{~s}, 12 \mathrm{H}$ ).

${ }^{13} \mathrm{C} \mathrm{NMR}(400 \mathrm{MHz}, \mathrm{CDCl} 3) \delta$ (ppm): 153.9, 88.99, 22.36<smiles>CC1(Cl)OC(=O)OC1(Cl)Cl</smiles>

a

$\begin{array}{lllllllllllll}7.0 & 6.5 & 6.0 & 5.5 & 5.0 & 4.5 & \begin{array}{r}4.0 \\ \mathrm{f} 1(\mathrm{ppm})\end{array} & 3.0 & 2.5 & 2.0 & 1.5 & 1.0 & 0.5\end{array}$

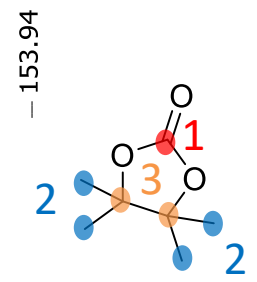

离

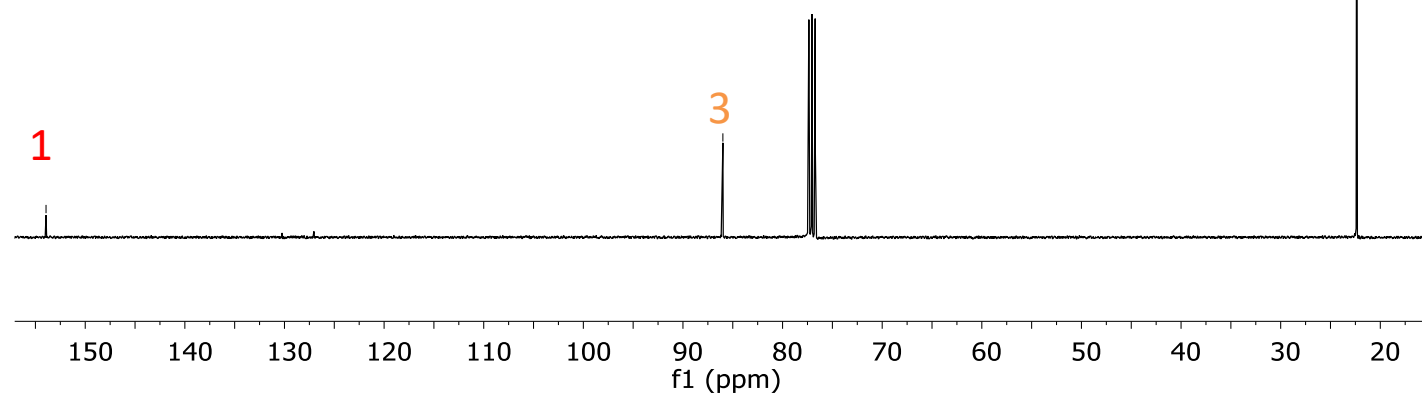


4-(Hydroxymethyl)-1,3-Dioxolan-2-one : The product was isolated as a colourless oil, $0.215 \mathrm{~g}$ (isolated yield $60 \%) .{ }^{1} \mathrm{H} \mathrm{NMR}\left(\mathrm{CDCl}_{3}, 400 \mathrm{MHz}\right) \delta(\mathrm{ppm}): 4.75(\mathrm{~m}, 1 \mathrm{H}), 4.46(\mathrm{dd}, J=8.30 \mathrm{~Hz}, J=8.46$ $\mathrm{Hz}, 1 \mathrm{H}) ; 4.40(\mathrm{dd}, J=6.74 \mathrm{~Hz}, J=8.23 \mathrm{~Hz}, 1 \mathrm{H}) ; 3.94(\mathrm{dd}, J=2.99 \mathrm{~Hz}, J=9.91 \mathrm{~Hz}, 1 \mathrm{H}) ; 3.66(\mathrm{dd}, J=$ $3.14 \mathrm{~Hz}, J=9.38 \mathrm{~Hz}, 1 \mathrm{H})$.

${ }^{13} \mathrm{C} \mathrm{NMR}\left(400 \mathrm{MHz}, \mathrm{CDCl}_{3}\right) \delta(\mathrm{ppm}): 155.3,76.6,65.8,61.7$
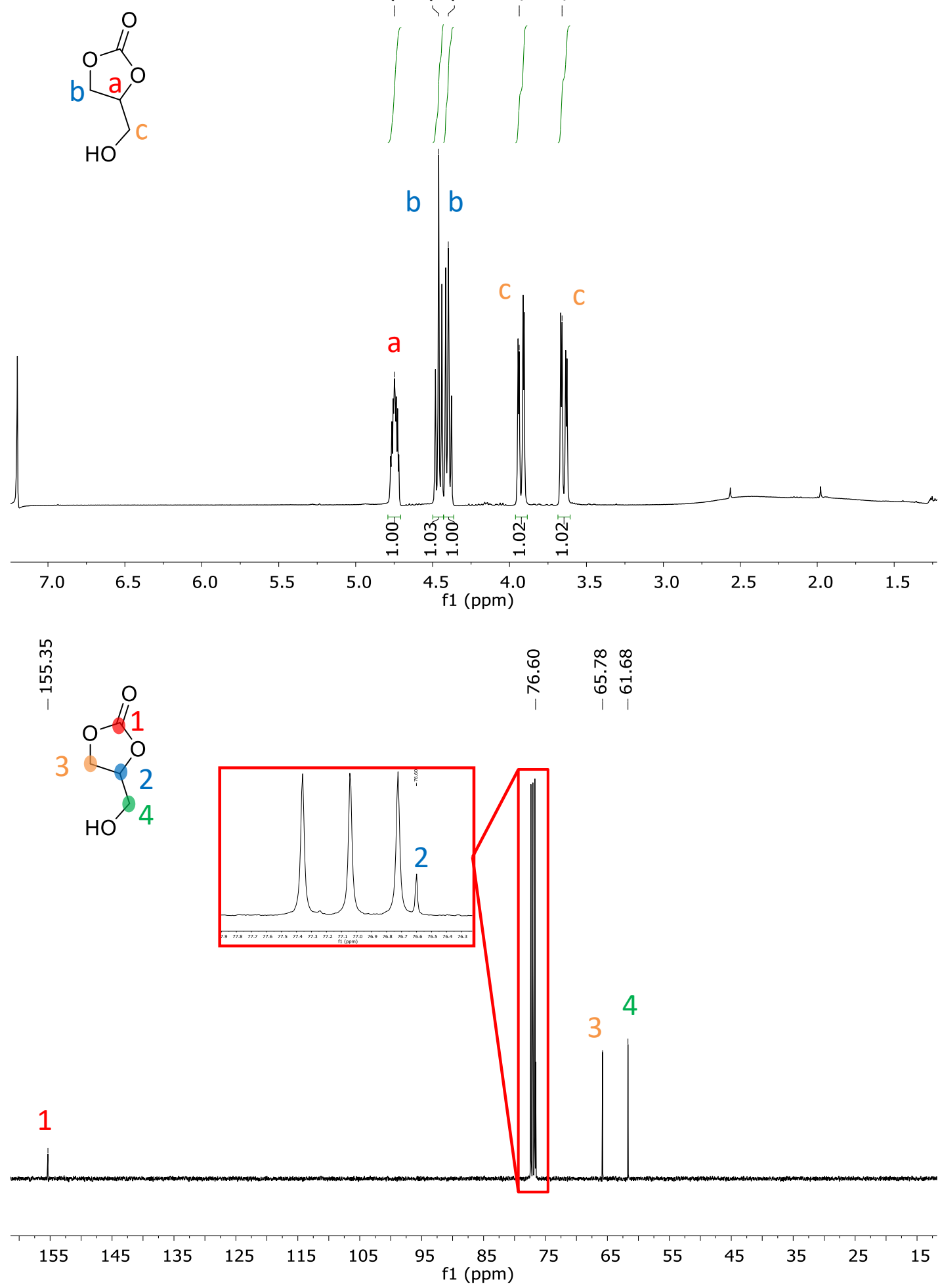
4,4,6-Trimethyl-1,3-Dioxan-2-one : The product was isolated as a white solid, $0.850 \mathrm{~g}$ (isolated yield 59 \%). ${ }^{1} \mathrm{H} \mathrm{NMR}\left(\mathrm{CDCl}_{3}, 400 \mathrm{MHz}\right) \delta(\mathrm{ppm}): 4.63(\mathrm{~m}, 1 \mathrm{H}), 1.95$ (dd, J $\left.=3.0 \mathrm{~Hz}, J=11.1 \mathrm{~Hz}, 1 \mathrm{H}\right) ; 1.74$ (dd, $J=12.2 \mathrm{~Hz}, J=13.8 \mathrm{~Hz}, 2 \mathrm{H}) ; 1.45(\mathrm{~s}, 6 \mathrm{H}) ; 1.40(\mathrm{~d}, J=6.2 \mathrm{~Hz}, 3 \mathrm{H}$ ).

${ }^{13} \mathrm{C} \mathrm{NMR}(\mathrm{CDCl} 3,100 \mathrm{MHz}) \delta$ (ppm): 149.5, 80.9, 72.3, 40.5, 29.9, 26.5, 21.1.
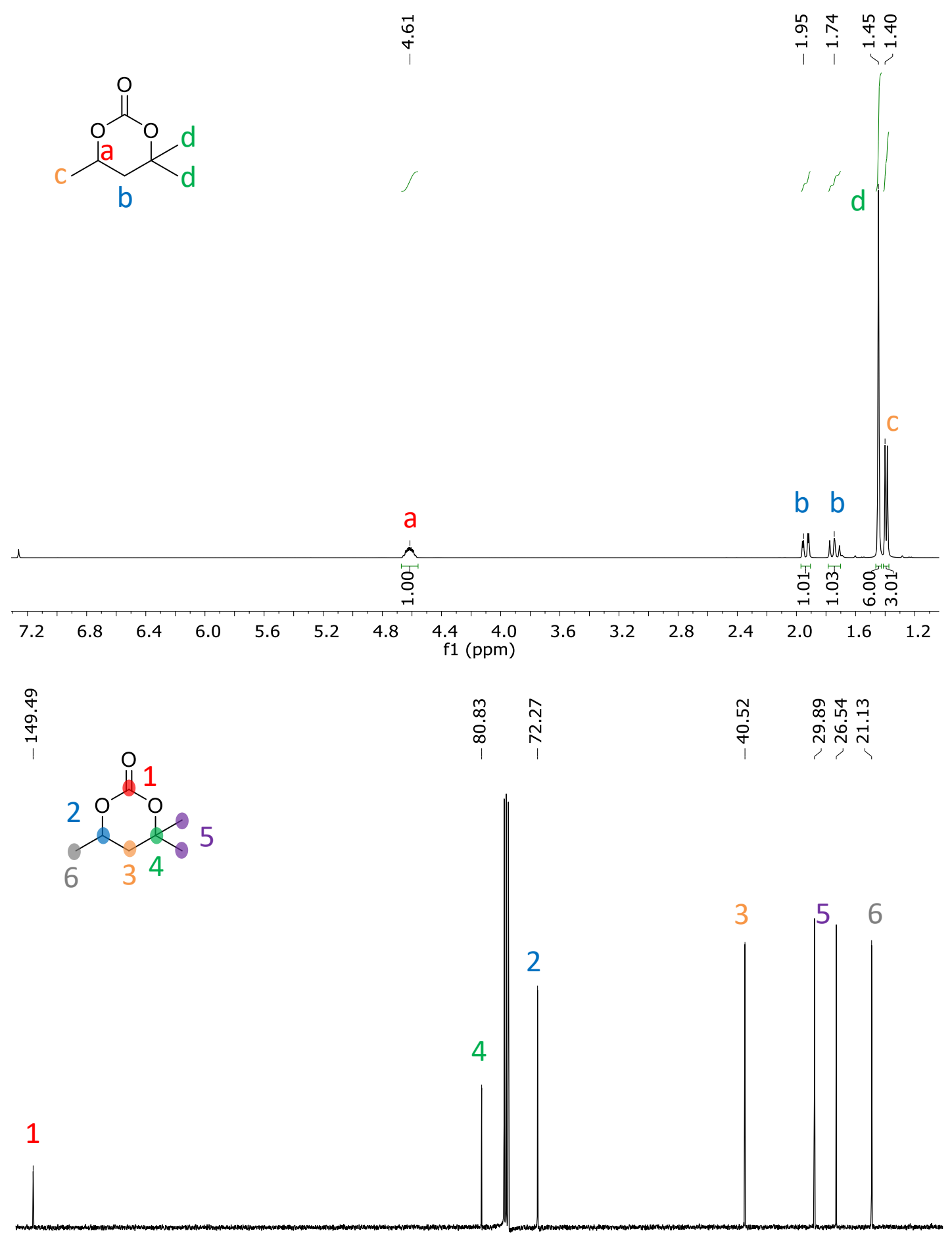

$\begin{array}{lllllllllllll}145 & 135 & 125 & 115 & 105 & 95 & \begin{array}{l}85 \\ \mathrm{f} 1(\mathrm{ppm})\end{array} & 65 & 55 & 45 & 35 & 25 & 15\end{array}$


4-Methyl-[1,3]-dioxan-2-one : The product was isolated as a colourless oil, $0.452 \mathrm{~g}$ (isolated yield 39 \%). ${ }^{1} \mathrm{H}$ NMR $\left(\mathrm{CDCl}_{3}, 400 \mathrm{MHz}\right) \delta(\mathrm{ppm}):$ 4.57-4.65 (m, $\left.1 \mathrm{H}\right), 4.34-4.46(\mathrm{~m}, 2 \mathrm{H}), 2.04-2.11(\mathrm{~m}, 1 \mathrm{H})$, 1.86-1.96 (m, $1 \mathrm{H}), 1.44(\mathrm{~d}, \mathrm{~J}=6.3,3 \mathrm{H}$.

${ }^{13} \mathrm{C} \mathrm{NMR}\left(\mathrm{CDCl}_{3}, 400 \mathrm{MHz}\right) \delta$ (ppm): 148.9, 75.7, 66.9, 28.7, 21.1

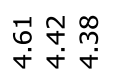

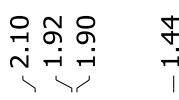<smiles>O=C1CC(Cl)C[C-]O1</smiles>

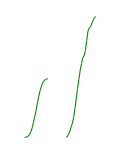

d

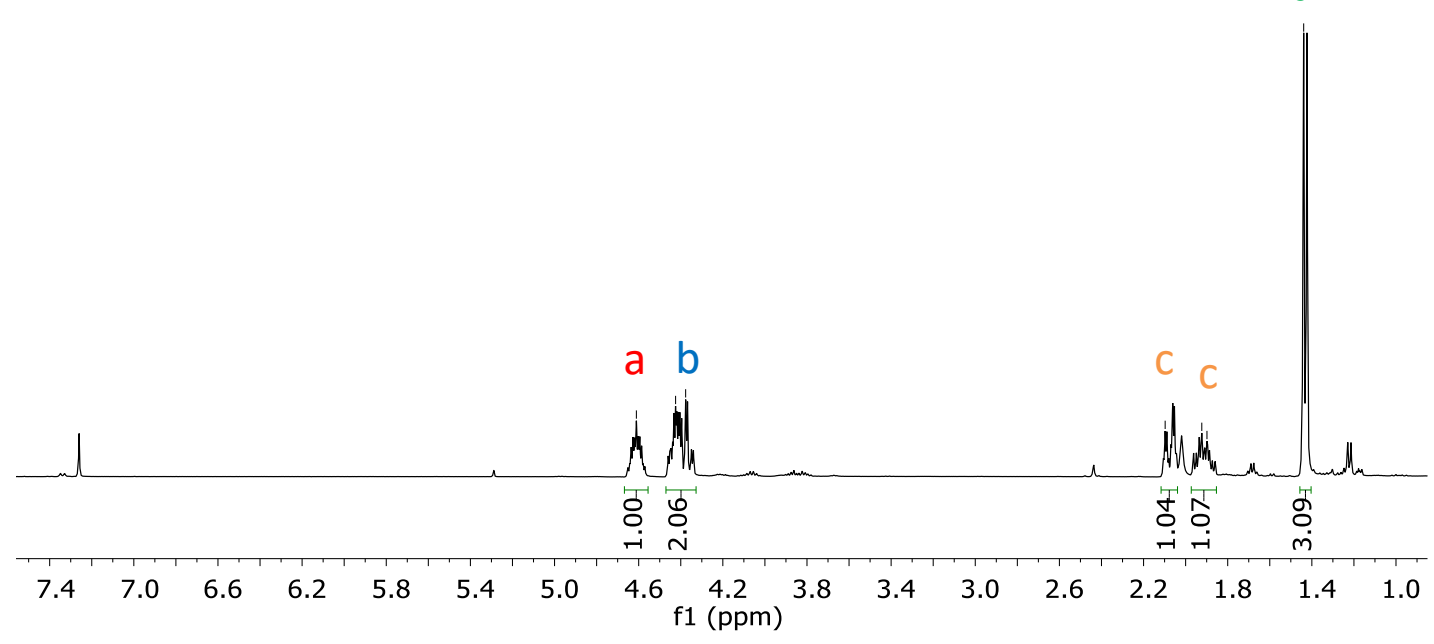

n̊
守
।

\begin{tabular}{cc}
\multirow{1}{*}{} & 8 \\
\multirow{1}{*}{} & 0 \\
1 & 1
\end{tabular}

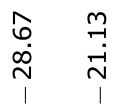<smiles></smiles>

1

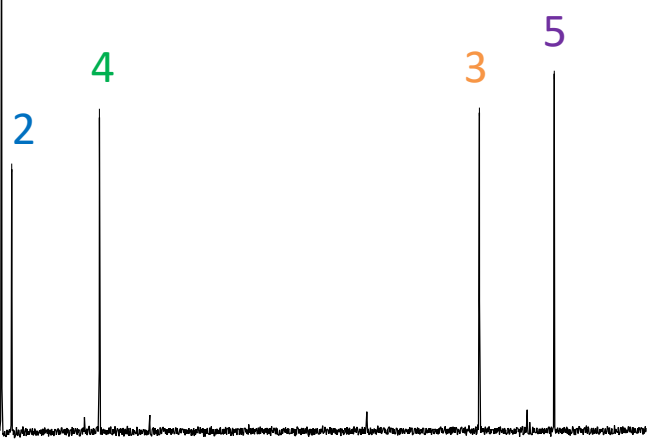

$\begin{array}{llllllllllllll}145 & 135 & 125 & 115 & 105 & 95 & \begin{array}{c}85 \\ \mathrm{f} 1(\mathrm{ppm})\end{array} & 75 & 65 & 55 & 45 & 35 & 25 & 15\end{array}$


Hexahydro-,(3aR,7aR)-1,3-benzodioxol-2-one : The product was isolated as a white solid, $0.255 \mathrm{~g}$ (isolated yield $60 \%$ ). ${ }^{1} \mathrm{H}$ NMR $(400 \mathrm{MHz}, \mathrm{CDCl} 3) \delta$ (ppm): 3.98-4.05 (m, $\left.2 \mathrm{H}\right), 2.23-2.30(\mathrm{~m}, 2 \mathrm{H}), 1.88-$ $1.98(\mathrm{~m}, 2 \mathrm{H}), 1.63-1.73(\mathrm{~m}, 2 \mathrm{H}), 1.37-1.44(\mathrm{~m}, 2 \mathrm{H})$.

13C NMR (400 MHz, CDCl3) $\delta$ (ppm): 155.0, 83.5, 28.2, 23.2

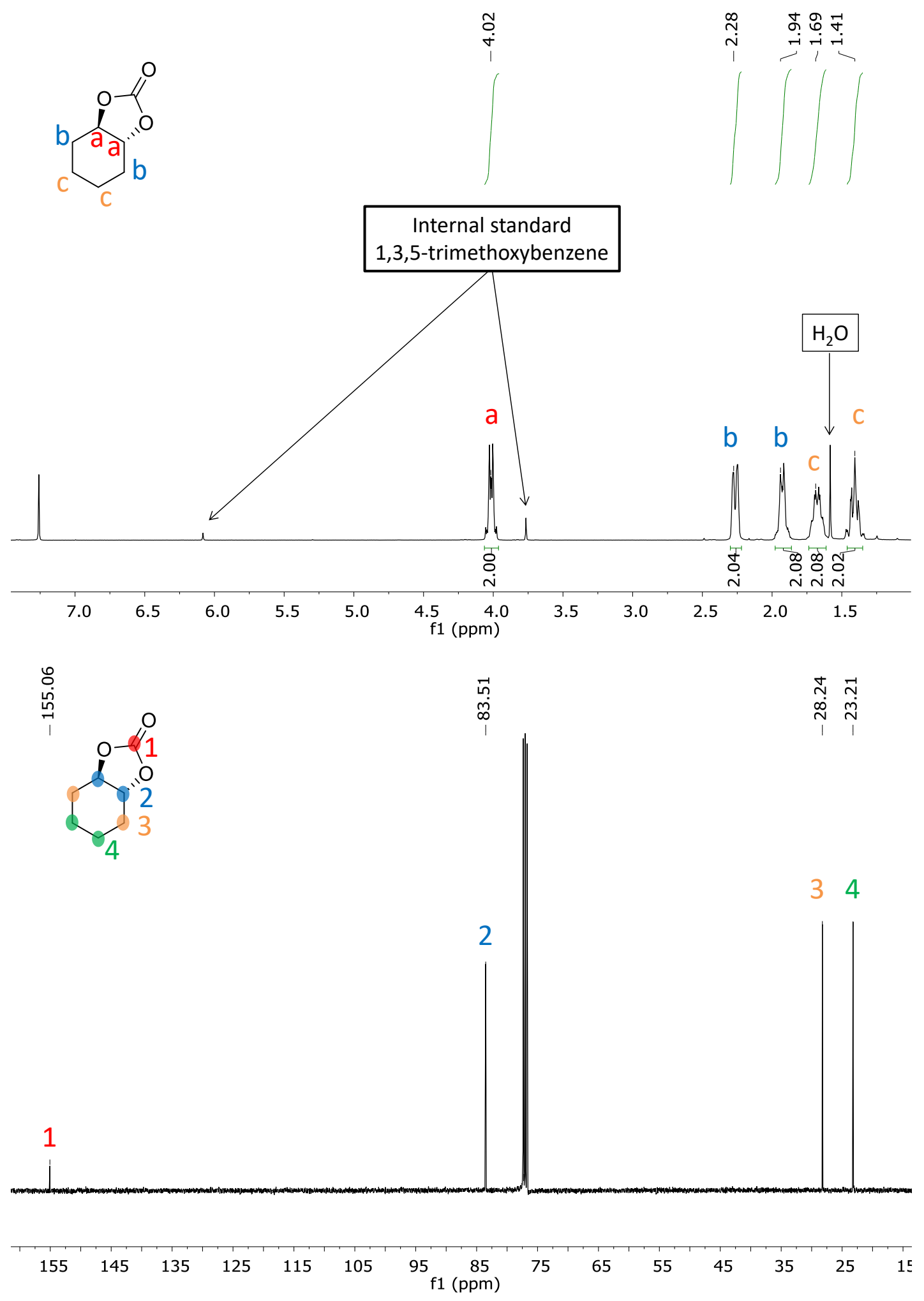


Optimized structures at the $M 062 X / 6-311 g(d, p)$ level of the intermediates and transition states for the reaction path of the model reaction with PG, DBU (2eq), $\mathrm{EtBr}(2 \mathrm{eq}), \mathrm{CO}_{2}$ (2eq) calculated with the (R) primary alcohol

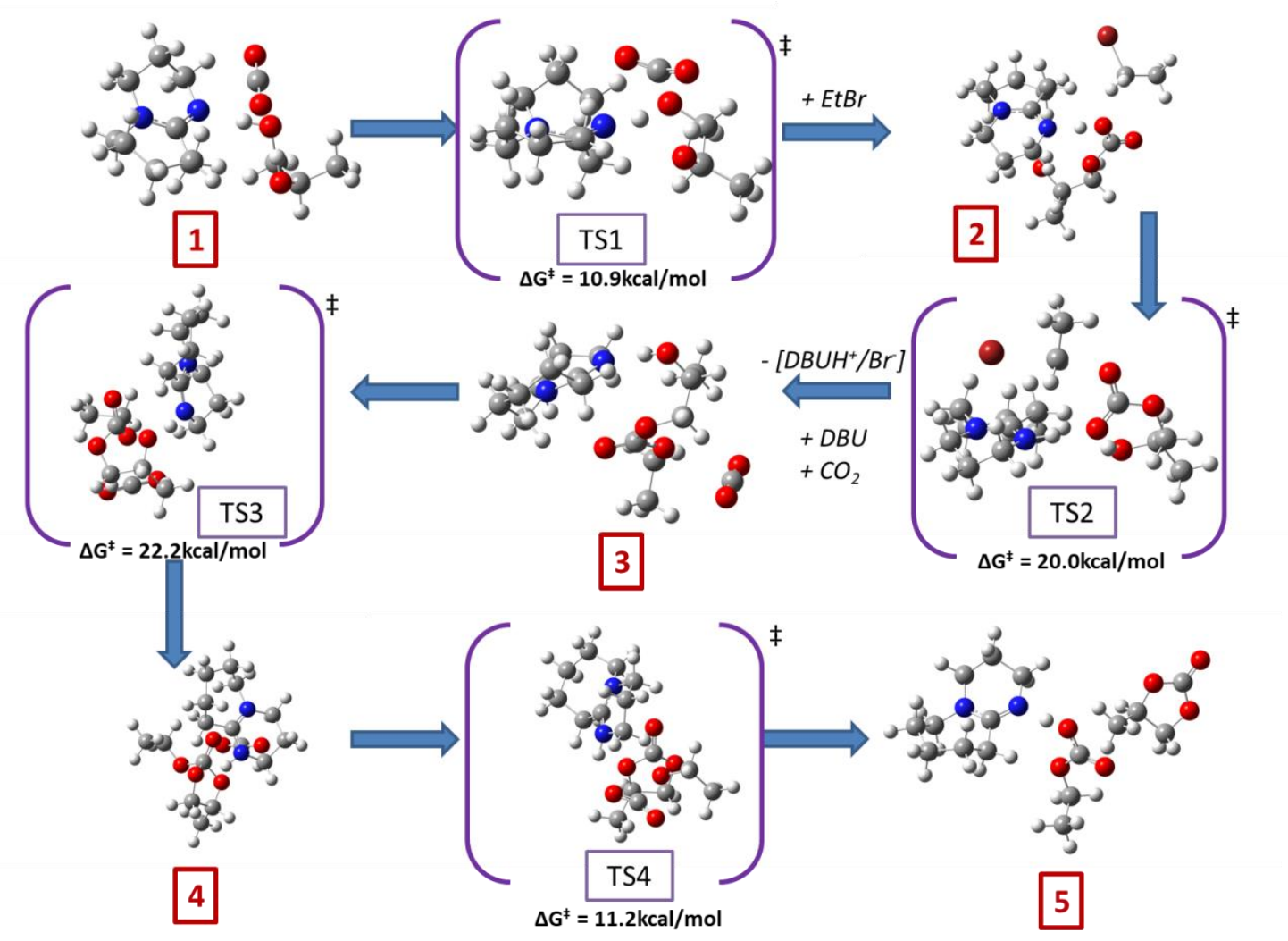

TS1:

\begin{tabular}{lrrr}
01 & \multicolumn{2}{c}{$Y$} & \\
C & 2.131972 & 2.698591 & 0.561076 \\
C & 0.782169 & 1.984667 & 0.481838 \\
C & 0.541781 & 1.216272 & -0.829914 \\
C & 3.345475 & 1.769619 & 0.505221 \\
C & 1.15716 & -0.156586 & -0.819161 \\
C & 3.379772 & 0.906746 & -0.758819 \\
H & 2.20289 & 3.415736 & -0.266263 \\
H & 0.670566 & 1.290371 & 1.320702 \\
$H$ & -0.530051 & 1.093669 & -0.965639 \\
H & 4.259698 & 2.369188 & 0.542358 \\
H & 4.385729 & 0.517461 & -0.926521 \\
C & 3.132229 & -1.523168 & -0.306941 \\
$H$ & 3.87726 & -1.294355 & 0.460566
\end{tabular}




\begin{tabular}{|c|c|c|c|}
\hline$N$ & 2.498979 & -0.259608 & -0.699927 \\
\hline $\mathrm{N}$ & 0.362704 & -1.181172 & -0.875277 \\
\hline $\mathrm{H}$ & 3.130596 & 1.509612 & -1.636259 \\
\hline $\mathrm{H}$ & 3.358062 & 1.108922 & 1.379163 \\
\hline $\mathrm{H}$ & 2.173047 & 3.283835 & 1.483312 \\
\hline $\mathrm{H}$ & -0.020046 & 2.719926 & 0.574655 \\
\hline $\mathrm{H}$ & 0.918097 & 1.790429 & -1.683401 \\
\hline $\mathrm{H}$ & 3.659529 & -1.947433 & -1.169278 \\
\hline C & 2.097072 & -2.495229 & 0.231218 \\
\hline $\mathrm{H}$ & 2.542476 & -3.484619 & 0.344494 \\
\hline C & 0.916804 & -2.521114 & -0.730691 \\
\hline $\mathrm{H}$ & 1.225831 & -2.904408 & -1.710414 \\
\hline $\mathrm{H}$ & 0.116935 & -3.160955 & -0.355121 \\
\hline $\mathrm{H}$ & 1.733431 & -2.155891 & 1.203923 \\
\hline C & -3.077203 & -0.884805 & -0.325922 \\
\hline C & -3.119033 & 0.477034 & -1.013414 \\
\hline 0 & -2.616829 & 1.497644 & -0.165286 \\
\hline $\mathrm{H}$ & -2.820106 & 1.260354 & 0.749464 \\
\hline $\mathrm{O}$ & -1.822015 & -1.183555 & 0.236565 \\
\hline $\mathrm{H}$ & -0.854198 & -1.106923 & -0.408683 \\
\hline C & -1.454922 & -0.578585 & 1.862149 \\
\hline 0 & -2.436452 & -0.035301 & 2.262553 \\
\hline 0 & -0.327381 & -0.898716 & 2.049309 \\
\hline $\mathrm{H}$ & -3.352522 & -1.667483 & -1.041387 \\
\hline $\mathrm{H}$ & -3.810681 & -0.89677 & 0.487984 \\
\hline C & -4.530072 & 0.803158 & -1.48287 \\
\hline $\mathrm{H}$ & -4.544155 & 1.785059 & -1.956278 \\
\hline $\mathrm{H}$ & -4.893028 & 0.061776 & -2.199415 \\
\hline $\mathrm{H}$ & -5.212556 & 0.825563 & -0.62911 \\
\hline $\mathrm{H}$ & -2.446406 & 0.452219 & -1.880181 \\
\hline
\end{tabular}

TS2:

\begin{tabular}{lrrr}
01 & \multicolumn{2}{c}{$\mathrm{Y}$} \\
$\mathrm{C}$ & -1.191798 & -3.372695 & -1.77191 \\
$\mathrm{C}$ & -0.044413 & -2.732394 & -0.992781 \\
$\mathrm{C}$ & -0.223771 & -1.22361 & -0.756683 \\
$\mathrm{C}$ & -2.547553 & -3.30416 & -1.069561 \\
$\mathrm{C}$ & -1.093386 & -0.891681 & 0.420131 \\
$\mathrm{C}$ & -2.997998 & -1.883584 & -0.728372 \\
$\mathrm{H}$ & -1.274761 & -2.873759 & -2.744455 \\
$\mathrm{H}$ & 0.095199 & -3.234067 & -0.029666 \\
$\mathrm{H}$ & 0.750408 & -0.767309 & -0.59035 \\
$\mathrm{H}$ & -3.306682 & -3.749059 & -1.718749 \\
$\mathrm{H}$ & -4.065809 & -1.875245 & -0.510709 \\
$\mathrm{C}$ & -3.235212 & -0.941706 & 1.567959
\end{tabular}




\begin{tabular}{|c|c|c|c|}
\hline $\mathrm{H}$ & -3.940383 & -1.760491 & 1.721915 \\
\hline$N$ & -2.345186 & -1.329502 & 0.467637 \\
\hline$N$ & -0.553778 & -0.205981 & 1.404724 \\
\hline $\mathrm{H}$ & -2.847194 & -1.193071 & -1.563889 \\
\hline $\mathrm{H}$ & -2.52956 & -3.894883 & -0.147544 \\
\hline $\mathrm{H}$ & -0.948403 & -4.418088 & -1.977661 \\
\hline $\mathrm{H}$ & 0.891805 & -2.86323 & -1.537757 \\
\hline $\mathrm{H}$ & -0.66589 & -0.739169 & -1.635065 \\
\hline $\mathrm{H}$ & -3.785707 & -0.048606 & 1.253362 \\
\hline C & -2.444847 & -0.671267 & 2.83811 \\
\hline $\mathrm{H}$ & -3.109522 & -0.261544 & 3.599 \\
\hline C & -1.326004 & 0.309269 & 2.526558 \\
\hline $\mathrm{H}$ & -1.738328 & 1.284739 & 2.247606 \\
\hline $\mathrm{H}$ & -0.649721 & 0.4329 & 3.371897 \\
\hline $\mathrm{H}$ & -2.021177 & -1.603476 & 3.220157 \\
\hline C & 4.570644 & 0.245832 & 0.498269 \\
\hline $\mathrm{H}$ & 4.284749 & 0.085738 & 1.542232 \\
\hline $\mathrm{H}$ & 5.620421 & 0.536557 & 0.454507 \\
\hline $\mathrm{C}$ & 4.371512 & -1.037392 & -0.302589 \\
\hline 0 & 3.868629 & 1.365384 & -0.043208 \\
\hline $\mathrm{H}$ & 0.409249 & 0.145826 & 1.266274 \\
\hline 0 & 3.104534 & -1.636201 & -0.063259 \\
\hline $\mathrm{H}$ & 2.591566 & -0.999923 & 0.456793 \\
\hline C & 2.55058 & 1.505023 & 0.234454 \\
\hline 0 & 2.031733 & 2.523689 & -0.261793 \\
\hline 0 & 1.984931 & 0.624136 & 0.930069 \\
\hline C & -0.063206 & 3.806582 & -1.169093 \\
\hline $\mathrm{H}$ & -0.413953 & 3.696377 & -2.193163 \\
\hline $\mathrm{H}$ & 0.929264 & 4.257975 & -1.172603 \\
\hline $\mathrm{H}$ & -0.75487 & 4.452823 & -0.632352 \\
\hline C & 0.02985 & 2.470683 & -0.498742 \\
\hline $\mathrm{H}$ & 0.201953 & 1.573898 & -1.067401 \\
\hline $\mathrm{H}$ & -0.070264 & 2.380349 & 0.569241 \\
\hline $\mathrm{Br}$ & -2.39103 & 1.871764 & -0.682047 \\
\hline $\mathrm{H}$ & 4.443627 & -0.771081 & -1.364781 \\
\hline C & 5.45089 & -2.05147 & 0.046046 \\
\hline $\mathrm{H}$ & 5.239966 & -2.991326 & -0.4646 \\
\hline $\mathrm{H}$ & 6.44115 & -1.702178 & -0.254328 \\
\hline $\mathrm{H}$ & 5.451302 & -2.244691 & 1.121983 \\
\hline
\end{tabular}

TS3:

\begin{tabular}{lrrr}
01 & $X$ & \multicolumn{2}{c}{$Z$} \\
$C$ & -1.191798 & -3.372695 & -1.77191 \\
$C$ & -0.044413 & -2.732394 & -0.992781 \\
$C$ & -0.223771 & -1.22361 & -0.756683
\end{tabular}




\begin{tabular}{|c|c|c|c|}
\hline$C$ & -2.547553 & -3.30416 & -1.069561 \\
\hline$C$ & -1.093386 & -0.891681 & 0.420131 \\
\hline$C$ & -2.997998 & -1.883584 & -0.728372 \\
\hline $\mathrm{H}$ & -1.274761 & -2.873759 & -2.744455 \\
\hline $\mathrm{H}$ & 0.095199 & -3.234067 & -0.029666 \\
\hline $\mathrm{H}$ & 0.750408 & -0.767309 & -0.59035 \\
\hline $\mathrm{H}$ & -3.306682 & -3.749059 & -1.718749 \\
\hline $\mathrm{H}$ & -4.065809 & -1.875245 & -0.510709 \\
\hline$C$ & -3.235212 & -0.941706 & 1.567959 \\
\hline $\mathrm{H}$ & -3.940383 & -1.760491 & 1.721915 \\
\hline$N$ & -2.345186 & -1.329502 & 0.467637 \\
\hline$N$ & -0.553778 & -0.205981 & 1.404724 \\
\hline $\mathrm{H}$ & -2.847194 & -1.193071 & -1.563889 \\
\hline $\mathrm{H}$ & -2.52956 & -3.894883 & -0.147544 \\
\hline $\mathrm{H}$ & -0.948403 & -4.418088 & -1.977661 \\
\hline $\mathrm{H}$ & 0.891805 & -2.86323 & -1.537757 \\
\hline $\mathrm{H}$ & -0.66589 & -0.739169 & -1.635065 \\
\hline $\mathrm{H}$ & -3.785707 & -0.048606 & 1.253362 \\
\hline$C$ & -2.444847 & -0.671267 & 2.83811 \\
\hline $\mathrm{H}$ & -3.109522 & -0.261544 & 3.599 \\
\hline$C$ & -1.326004 & 0.309269 & 2.526558 \\
\hline $\mathrm{H}$ & -1.738328 & 1.284739 & 2.247606 \\
\hline $\mathrm{H}$ & -0.649721 & 0.4329 & 3.371897 \\
\hline $\mathrm{H}$ & -2.021177 & -1.603476 & 3.220157 \\
\hline$C$ & 4.570644 & 0.245832 & 0.498269 \\
\hline $\mathrm{H}$ & 4.284749 & 0.085738 & 1.542232 \\
\hline $\mathrm{H}$ & 5.620421 & 0.536557 & 0.454507 \\
\hline$C$ & 4.371512 & -1.037392 & -0.302589 \\
\hline 0 & 3.868629 & 1.365384 & -0.043208 \\
\hline $\mathrm{H}$ & 0.409249 & 0.145826 & 1.266274 \\
\hline 0 & 3.104534 & -1.636201 & -0.063259 \\
\hline $\mathrm{H}$ & 2.591566 & -0.999923 & 0.456793 \\
\hline$C$ & 2.55058 & 1.505023 & 0.234454 \\
\hline 0 & 2.031733 & 2.523689 & -0.261793 \\
\hline 0 & 1.984931 & 0.624136 & 0.930069 \\
\hline$C$ & -0.063206 & 3.806582 & -1.169093 \\
\hline $\mathrm{H}$ & -0.413953 & 3.696377 & -2.193163 \\
\hline $\mathrm{H}$ & 0.929264 & 4.257975 & -1.172603 \\
\hline $\mathrm{H}$ & -0.75487 & 4.452823 & -0.632352 \\
\hline$C$ & 0.02985 & 2.470683 & -0.498742 \\
\hline $\mathrm{H}$ & 0.201953 & 1.573898 & -1.067401 \\
\hline $\mathrm{H}$ & -0.070264 & 2.380349 & 0.569241 \\
\hline $\mathrm{Br}$ & -2.39103 & 1.871764 & -0.682047 \\
\hline $\mathrm{H}$ & 4.443627 & -0.771081 & -1.364781 \\
\hline$C$ & 5.45089 & -2.05147 & 0.046046 \\
\hline $\mathrm{H}$ & 5.239966 & -2.991326 & -0.4646 \\
\hline
\end{tabular}


$-0.254328$

TS4:

\begin{tabular}{|c|c|c|c|}
\hline 01 & $x$ & $Y$ & Z \\
\hline C & -1.191798 & -3.372695 & -1.77191 \\
\hline C & -0.044413 & -2.732394 & -0.992781 \\
\hline C & -0.223771 & -1.22361 & -0.756683 \\
\hline C & -2.547553 & -3.30416 & -1.069561 \\
\hline C & -1.093386 & -0.891681 & 0.420131 \\
\hline C & -2.997998 & -1.883584 & -0.728372 \\
\hline $\mathrm{H}$ & -1.274761 & -2.873759 & -2.744455 \\
\hline $\mathrm{H}$ & 0.095199 & -3.234067 & -0.029666 \\
\hline $\mathrm{H}$ & 0.750408 & -0.767309 & -0.59035 \\
\hline $\mathrm{H}$ & -3.306682 & -3.749059 & -1.718749 \\
\hline $\mathrm{H}$ & -4.065809 & -1.875245 & -0.510709 \\
\hline C & -3.235212 & -0.941706 & 1.567959 \\
\hline $\mathrm{H}$ & -3.940383 & -1.760491 & 1.721915 \\
\hline$N$ & -2.345186 & -1.329502 & 0.467637 \\
\hline $\mathrm{N}$ & -0.553778 & -0.205981 & 1.404724 \\
\hline $\mathrm{H}$ & -2.847194 & -1.193071 & -1.563889 \\
\hline $\mathrm{H}$ & -2.52956 & -3.894883 & -0.147544 \\
\hline $\mathrm{H}$ & -0.948403 & -4.418088 & -1.977661 \\
\hline $\mathrm{H}$ & 0.891805 & -2.86323 & -1.537757 \\
\hline $\mathrm{H}$ & -0.66589 & -0.739169 & -1.635065 \\
\hline $\mathrm{H}$ & -3.785707 & -0.048606 & 1.253362 \\
\hline C & -2.444847 & -0.671267 & 2.83811 \\
\hline $\mathrm{H}$ & -3.109522 & -0.261544 & 3.599 \\
\hline C & -1.326004 & 0.309269 & 2.526558 \\
\hline $\mathrm{H}$ & -1.738328 & 1.284739 & 2.247606 \\
\hline $\mathrm{H}$ & -0.649721 & 0.4329 & 3.371897 \\
\hline $\mathrm{H}$ & -2.021177 & -1.603476 & 3.220157 \\
\hline C & 4.570644 & 0.245832 & 0.498269 \\
\hline $\mathrm{H}$ & 4.284749 & 0.085738 & 1.542232 \\
\hline $\mathrm{H}$ & 5.620421 & 0.536557 & 0.454507 \\
\hline C & 4.371512 & -1.037392 & -0.302589 \\
\hline 0 & 3.868629 & 1.365384 & -0.043208 \\
\hline $\mathrm{H}$ & 0.409249 & 0.145826 & 1.266274 \\
\hline 0 & 3.104534 & -1.636201 & -0.063259 \\
\hline $\mathrm{H}$ & 2.591566 & -0.999923 & 0.456793 \\
\hline C & 2.55058 & 1.505023 & 0.234454 \\
\hline $\mathrm{O}$ & 2.031733 & 2.523689 & -0.261793 \\
\hline 0 & 1.984931 & 0.624136 & 0.930069 \\
\hline C & -0.063206 & 3.806582 & -1.169093 \\
\hline
\end{tabular}




$\begin{array}{lrrr}\mathrm{H} & -0.413953 & 3.696377 & -2.193163 \\ \mathrm{H} & 0.929264 & 4.257975 & -1.172603 \\ \mathrm{H} & -0.75487 & 4.452823 & -0.632352 \\ \mathrm{C} & 0.02985 & 2.470683 & -0.498742 \\ \mathrm{H} & 0.201953 & 1.573898 & -1.067401 \\ \mathrm{H} & -0.070264 & 2.380349 & 0.569241 \\ \mathrm{Br} & -2.39103 & 1.871764 & -0.682047 \\ \mathrm{H} & 4.443627 & -0.771081 & -1.364781 \\ \mathrm{C} & 5.45089 & -2.05147 & 0.046046 \\ \mathrm{H} & 5.239966 & -2.991326 & -0.4646 \\ \mathrm{H} & 6.44115 & -1.702178 & -0.254328 \\ \mathrm{H} & 5.451302 & -2.244691 & 1.121983\end{array}$

$\mathrm{XYZ}$ coordinates of the optimized structures at the $M 062 \mathrm{X} / 6-311 \mathrm{~g}(\mathrm{~d}, \mathrm{p})$ level of the transition states for comparison between biscarbonation or alkylation

\section{Propylene glycol as substrate}

TS ALKYLATION

\begin{tabular}{lrrr} 
O & \multicolumn{3}{c}{$\mathrm{Y}$} \\
$\mathrm{C}$ & -1.191798 & -3.372695 & -1.77191 \\
$\mathrm{C}$ & -0.044413 & -2.732394 & -0.992781 \\
$\mathrm{C}$ & -0.223771 & -1.22361 & -0.756683 \\
$\mathrm{C}$ & -2.547553 & -3.30416 & -1.069561 \\
$\mathrm{C}$ & -1.093386 & -0.891681 & 0.420131 \\
$\mathrm{C}$ & -2.997998 & -1.883584 & -0.728372 \\
$\mathrm{H}$ & -1.274761 & -2.873759 & -2.744455 \\
$\mathrm{H}$ & 0.095199 & -3.234067 & -0.029666 \\
$\mathrm{H}$ & 0.750408 & -0.767309 & -0.59035 \\
$\mathrm{H}$ & -3.306682 & -3.749059 & -1.718749 \\
$\mathrm{H}$ & -4.065809 & -1.875245 & -0.510709 \\
$\mathrm{C}$ & -3.235212 & -0.941706 & 1.567959 \\
$\mathrm{H}$ & -3.940383 & -1.760491 & 1.721915 \\
$\mathrm{~N}$ & -2.345186 & -1.329502 & 0.467637 \\
$\mathrm{~N}$ & -0.553778 & -0.205981 & 1.404724 \\
$\mathrm{H}$ & -2.847194 & -1.193071 & -1.563889 \\
$\mathrm{H}$ & -2.52956 & -3.894883 & -0.147544 \\
$\mathrm{H}$ & -0.948403 & -4.418088 & -1.977661 \\
$\mathrm{H}$ & 0.891805 & -2.86323 & -1.537757 \\
$\mathrm{H}$ & -0.66589 & -0.739169 & -1.635065
\end{tabular}




\begin{tabular}{|c|c|c|c|}
\hline $\mathrm{H}$ & -3.785707 & -0.048606 & 1.253362 \\
\hline C & -2.444847 & -0.671267 & 2.83811 \\
\hline $\mathrm{H}$ & -3.109522 & -0.261544 & 3.599 \\
\hline C & -1.326004 & 0.309269 & 2.526558 \\
\hline $\mathrm{H}$ & -1.738328 & 1.284739 & 2.247606 \\
\hline $\mathrm{H}$ & -0.649721 & 0.4329 & 3.371897 \\
\hline $\mathrm{H}$ & -2.021177 & -1.603476 & 3.220157 \\
\hline C & 4.570644 & 0.245832 & 0.498269 \\
\hline $\mathrm{H}$ & 4.284749 & 0.085738 & 1.542232 \\
\hline $\mathrm{H}$ & 5.620421 & 0.536557 & 0.454507 \\
\hline C & 4.371512 & -1.037392 & -0.302589 \\
\hline 0 & 3.868629 & 1.365384 & -0.043208 \\
\hline $\mathrm{H}$ & 0.409249 & 0.145826 & 1.266274 \\
\hline 0 & 3.104534 & -1.636201 & -0.063259 \\
\hline $\mathrm{H}$ & 2.591566 & -0.999923 & 0.456793 \\
\hline $\mathrm{C}$ & 2.55058 & 1.505023 & 0.234454 \\
\hline $\mathrm{O}$ & 2.031733 & 2.523689 & -0.261793 \\
\hline 0 & 1.984931 & 0.624136 & 0.930069 \\
\hline C & -0.063206 & 3.806582 & -1.169093 \\
\hline $\mathrm{H}$ & -0.413953 & 3.696377 & -2.193163 \\
\hline $\mathrm{H}$ & 0.929264 & 4.257975 & -1.172603 \\
\hline $\mathrm{H}$ & -0.75487 & 4.452823 & -0.632352 \\
\hline $\mathrm{C}$ & 0.02985 & 2.470683 & -0.498742 \\
\hline $\mathrm{H}$ & 0.201953 & 1.573898 & -1.067401 \\
\hline $\mathrm{H}$ & -0.070264 & 2.380349 & 0.569241 \\
\hline $\mathrm{Br}$ & -2.39103 & 1.871764 & -0.682047 \\
\hline $\mathrm{H}$ & 4.443627 & -0.771081 & -1.364781 \\
\hline$C$ & 5.45089 & -2.05147 & 0.046046 \\
\hline $\mathrm{H}$ & 5.239966 & -2.991326 & -0.4646 \\
\hline $\mathrm{H}$ & 6.44115 & -1.702178 & -0.254328 \\
\hline $\mathrm{H}$ & 5.451302 & -2.244691 & 1.121983 \\
\hline
\end{tabular}

\section{TS BISCARBONATION}

\begin{tabular}{lrrr} 
O 1 & \multicolumn{2}{c}{$\mathrm{Y}$} \\
$\mathrm{C}$ & 5.896744 & 1.359414 & -1.903946 \\
$\mathrm{C}$ & 5.024955 & 2.004856 & -0.829043 \\
$\mathrm{C}$ & 3.688607 & 1.284353 & -0.597751 \\
$\mathrm{C}$ & 6.358428 & -0.053251 & -1.557666 \\
$\mathrm{C}$ & 3.760553 & 0.08221 & 0.294017 \\
$\mathrm{C}$ & 5.215029 & -1.028819 & -1.290168 \\
$\mathrm{H}$ & 5.328612 & 1.32664 & -2.840262 \\
$\mathrm{H}$ & 5.577257 & 2.075755 & 0.113981 \\
$\mathrm{H}$ & 2.958881 & 1.970261 & -0.166499 \\
$\mathrm{H}$ & 6.944597 & -0.449664 & -2.391289 \\
$\mathrm{H}$ & 5.591697 & -2.049927 & -1.340484
\end{tabular}




\begin{tabular}{|c|c|c|c|}
\hline C & 4.495979 & -2.165692 & 0.78889 \\
\hline $\mathrm{H}$ & 5.480564 & -2.635499 & 0.790064 \\
\hline$N$ & 4.614807 & -0.899063 & 0.050304 \\
\hline$N$ & 2.964974 & 0.062173 & 1.351386 \\
\hline $\mathrm{H}$ & 4.407006 & -0.95379 & -2.024184 \\
\hline $\mathrm{H}$ & 7.01813 & -0.035031 & -0.683815 \\
\hline $\mathrm{H}$ & 6.770471 & 1.990207 & -2.086803 \\
\hline $\mathrm{H}$ & 4.794102 & 3.02824 & -1.131903 \\
\hline $\mathrm{H}$ & 3.238466 & 0.929614 & -1.531684 \\
\hline $\mathrm{H}$ & 3.785867 & -2.78449 & 0.230736 \\
\hline C & 4.01142 & -1.930887 & 2.208776 \\
\hline $\mathrm{H}$ & 3.839216 & -2.891332 & 2.695156 \\
\hline C & 2.721877 & -1.130748 & 2.163204 \\
\hline $\mathrm{H}$ & 1.909698 & -1.705114 & 1.704843 \\
\hline $\mathrm{H}$ & 2.417671 & -0.801266 & 3.156752 \\
\hline $\mathrm{H}$ & 4.76878 & -1.388223 & 2.780524 \\
\hline C & -5.298428 & 0.529742 & -2.402024 \\
\hline C & -4.171841 & 1.11781 & -1.55056 \\
\hline C & -4.371047 & 0.965437 & -0.031171 \\
\hline C & -5.496946 & -0.978921 & -2.250731 \\
\hline C & -3.929269 & -0.385877 & 0.463336 \\
\hline C & -5.772205 & -1.406317 & -0.807146 \\
\hline $\mathrm{H}$ & -6.235879 & 1.033186 & -2.135955 \\
\hline $\mathrm{H}$ & -3.212075 & 0.670785 & -1.833 \\
\hline $\mathrm{H}$ & -3.794358 & 1.71619 & 0.509356 \\
\hline $\mathrm{H}$ & -6.340402 & -1.291637 & -2.873106 \\
\hline $\mathrm{H}$ & -6.220196 & -2.400978 & -0.785455 \\
\hline C & -4.018381 & -2.828531 & 0.248242 \\
\hline $\mathrm{H}$ & -4.154602 & -3.400846 & -0.673422 \\
\hline$N$ & -4.567612 & -1.486535 & 0.018716 \\
\hline$N$ & -2.907218 & -0.430579 & 1.262175 \\
\hline $\mathrm{H}$ & -6.494646 & -0.729949 & -0.341934 \\
\hline $\mathrm{H}$ & -4.614337 & -1.519004 & -2.610851 \\
\hline $\mathrm{H}$ & -5.109661 & 0.761246 & -3.453531 \\
\hline $\mathrm{H}$ & -4.089372 & 2.184864 & -1.769565 \\
\hline $\mathrm{H}$ & -5.421059 & 1.132234 & 0.229858 \\
\hline $\mathrm{H}$ & -4.597547 & -3.322226 & 1.037384 \\
\hline C & -2.545644 & -2.754172 & 0.611999 \\
\hline $\mathrm{H}$ & -2.196297 & -3.730297 & 0.95088 \\
\hline C & -2.346352 & -1.706251 & 1.694993 \\
\hline $\mathrm{H}$ & -2.821613 & -2.009813 & 2.634696 \\
\hline $\mathrm{H}$ & -1.280509 & -1.557714 & 1.865918 \\
\hline $\mathrm{H}$ & -1.935412 & -2.46759 & -0.247162 \\
\hline C & -0.19774 & 1.13551 & 0.964638 \\
\hline $\mathrm{H}$ & 0.177181 & 0.248929 & 1.493437 \\
\hline $\mathrm{H}$ & 0.514016 & 1.967457 & 1.082967 \\
\hline
\end{tabular}




$\begin{array}{lrrr}\mathrm{C} & -0.322104 & 0.791649 & -0.52256 \\ \mathrm{H} & -1.119333 & 0.050039 & -0.631825 \\ \mathrm{C} & -0.622878 & 2.023628 & -1.355642 \\ \mathrm{H} & 0.180004 & 2.757701 & -1.253214 \\ \mathrm{H} & -0.724534 & 1.755042 & -2.409 \\ \mathrm{H} & -1.549601 & 2.491378 & -1.015065 \\ \mathrm{O} & -1.424447 & 1.527791 & 1.509109 \\ \mathrm{H} & -2.253652 & 0.57373 & 1.441913 \\ \mathrm{O} & 0.896338 & 0.233458 & -0.995253 \\ \mathrm{H} & 2.289821 & 0.812114 & 1.409946 \\ \mathrm{C} & 1.143527 & -1.128694 & -0.69968 \\ \mathrm{C} & -1.764537 & 3.272339 & 1.650742 \\ \mathrm{O} & 2.229516 & -1.516098 & -1.152518 \\ \mathrm{O} & 0.300543 & -1.718982 & -0.009215 \\ \mathrm{O} & -2.936498 & 3.327547 & 1.842114 \\ \mathrm{O} & -0.730463 & 3.835544 & 1.503142\end{array}$

\section{Ethylene glycol as substrate}

\section{TS ALKYLATION}

\begin{tabular}{lrrr} 
O 1 & \multicolumn{3}{c}{$\mathrm{Z}$} \\
$\mathrm{C}$ & -1.69809 & -3.190549 & -1.743564 \\
$\mathrm{C}$ & -0.439784 & -2.811879 & -0.964656 \\
$\mathrm{C}$ & -0.280289 & -1.298278 & -0.744921 \\
$\mathrm{C}$ & -3.006964 & -2.814481 & -1.049823 \\
$\mathrm{C}$ & -1.058394 & -0.76918 & 0.423807 \\
$\mathrm{C}$ & -3.131658 & -1.325515 & -0.726048 \\
$\mathrm{H}$ & -1.66494 & -2.697384 & -2.722013 \\
$\mathrm{H}$ & -0.418232 & -3.320969 & 0.004435 \\
$\mathrm{H}$ & 0.770118 & -1.067675 & -0.576675 \\
$\mathrm{H}$ & -3.843979 & -3.087187 & -1.698434 \\
$\mathrm{H}$ & -4.171679 & -1.077793 & -0.514762 \\
$\mathrm{C}$ & -3.16146 & -0.327583 & 1.558696 \\
$\mathrm{H}$ & -4.03311 & -0.965497 & 1.715637 \\
$\mathrm{~N}$ & -2.376278 & -0.916906 & 0.468131 \\
$\mathrm{~N}$ & -0.382915 & -0.211116 & 1.405368 \\
$\mathrm{H}$ & -2.828317 & -0.695355 & -1.567777 \\
$\mathrm{H}$ & -3.123437 & -3.38362 & -0.12142 \\
$\mathrm{H}$ & -1.692106 & -4.266295 & -1.936313 \\
$\mathrm{H}$ & 0.445795 & -3.154044 & -1.502497 \\
$\mathrm{H}$ & -0.600402 & -0.736965 & -1.63039 \\
$\mathrm{H}$ & -3.49586 & 0.662829 & 1.231718 \\
$\mathrm{C}$ & -2.336171 & -0.228312 & 2.83149 \\
$\mathrm{H}$ & -2.895317 & 0.327613 & 3.584441 \\
$\mathrm{C}$ & -1.024589 & 0.473485 & 2.518979
\end{tabular}




\begin{tabular}{lrrr}
$\mathrm{H}$ & -1.20665 & 1.514258 & 2.230852 \\
$\mathrm{H}$ & -0.341325 & 0.449447 & 3.367433 \\
$\mathrm{H}$ & -2.134083 & -1.227885 & 3.224542 \\
$\mathrm{C}$ & 4.717277 & -0.902138 & 0.504683 \\
$\mathrm{H}$ & 4.428592 & -0.995488 & 1.554981 \\
$\mathrm{H}$ & 5.804386 & -0.865654 & 0.434121 \\
$\mathrm{C}$ & 4.203295 & -2.087375 & -0.299111 \\
$\mathrm{O}$ & 4.291155 & 0.360101 & -0.013711 \\
$\mathrm{H}$ & 0.634177 & -0.081899 & 1.26704 \\
$\mathrm{O}$ & 2.867351 & -2.453586 & -0.006299 \\
$\mathrm{H}$ & 2.493896 & -1.713749 & 0.494351 \\
$\mathrm{C}$ & 3.030718 & 0.77638 & 0.252013 \\
$\mathrm{O}$ & 2.751229 & 1.89307 & -0.225873 \\
$\mathrm{O}$ & 2.276988 & 0.02456 & 0.920124 \\
$\mathrm{C}$ & 0.992474 & 3.586829 & -1.172658 \\
$\mathrm{H}$ & 0.639607 & 3.545694 & -2.201109 \\
$\mathrm{H}$ & 2.058712 & 3.814488 & -1.164049 \\
$\mathrm{H}$ & 0.448798 & 4.371125 & -0.649757 \\
$\mathrm{C}$ & 0.787426 & 2.267981 & -0.493504 \\
$\mathrm{H}$ & 0.769295 & 1.349993 & -1.054127 \\
$\mathrm{H}$ & 0.657004 & 2.210798 & 0.57347 \\
$\mathrm{Br}$ & -1.702824 & 2.202563 & -0.707916 \\
$\mathrm{H}$ & 4.308537 & -1.845174 & -1.363375 \\
$\mathrm{H}$ & 4.847171 & -2.946622 & -0.083987 \\
& & & \\
\hline & & & \\
\hline & & &
\end{tabular}

\section{TS BISCARBONATION}

\begin{tabular}{lrrr} 
O & \multicolumn{3}{c}{$\mathrm{Y}$} \\
$\mathrm{C}$ & -5.89962 & 1.565235 & 1.828121 \\
$\mathrm{C}$ & -4.987354 & 2.151637 & 0.753075 \\
$\mathrm{C}$ & -3.670255 & 1.383194 & 0.569735 \\
$\mathrm{C}$ & -6.399029 & 0.158017 & 1.513298 \\
$\mathrm{C}$ & -3.76419 & 0.15907 & -0.289447 \\
$\mathrm{C}$ & -5.282406 & -0.860236 & 1.296546 \\
$\mathrm{H}$ & -5.350967 & 1.542434 & 2.776251 \\
$\mathrm{H}$ & -5.51895 & 2.212201 & -0.202523 \\
$\mathrm{H}$ & -2.910536 & 2.03359 & 0.135699 \\
$\mathrm{H}$ & -7.012988 & -0.195485 & 2.346221 \\
$\mathrm{H}$ & -5.692209 & -1.86719 & 1.368234 \\
$\mathrm{C}$ & -4.557025 & -2.078599 & -0.734465 \\
$\mathrm{H}$ & -5.553168 & -2.523216 & -0.73605 \\
$\mathrm{~N}$ & -4.653113 & -0.788082 & -0.035046 \\
$\mathrm{~N}$ & -2.950746 & 0.084414 & -1.330935 \\
$\mathrm{H}$ & -4.486269 & -0.789058 & 2.043839 \\
$\mathrm{H}$ & -7.041331 & 0.171224 & 0.626473 \\
$\mathrm{H}$ & -6.756449 & 2.227811 & 1.975169
\end{tabular}




\begin{tabular}{|c|c|c|c|}
\hline $\mathrm{H}$ & -4.729643 & 3.175613 & 1.031111 \\
\hline $\mathrm{H}$ & -3.251629 & 1.041102 & 1.522792 \\
\hline $\mathrm{H}$ & -3.870766 & -2.69878 & -0.148428 \\
\hline C & -4.04802 & -1.896919 & -2.153653 \\
\hline $\mathrm{H}$ & -3.897914 & -2.874735 & -2.611931 \\
\hline C & -2.735873 & -1.134211 & -2.112305 \\
\hline $\mathrm{H}$ & -1.946102 & -1.72097 & -1.631426 \\
\hline $\mathrm{H}$ & -2.412124 & -0.837302 & -3.110018 \\
\hline $\mathrm{H}$ & -4.78248 & -1.34842 & -2.749249 \\
\hline C & 5.534567 & 0.860639 & 2.113606 \\
\hline C & 4.437112 & 1.401058 & 1.194898 \\
\hline C & 4.581097 & 0.972617 & -0.275051 \\
\hline C & 5.626539 & -0.665671 & 2.183659 \\
\hline C & 4.016003 & -0.397929 & -0.521109 \\
\hline C & 5.850779 & -1.327408 & 0.820127 \\
\hline $\mathrm{H}$ & 6.499722 & 1.249802 & 1.766906 \\
\hline $\mathrm{H}$ & 3.449219 & 1.096943 & 1.558459 \\
\hline $\mathrm{H}$ & 4.048907 & 1.672277 & -0.917073 \\
\hline $\mathrm{H}$ & 6.455562 & -0.939968 & 2.842479 \\
\hline $\mathrm{H}$ & 6.241467 & -2.337636 & 0.949945 \\
\hline C & 3.988849 & -2.789195 & 0.040375 \\
\hline $\mathrm{H}$ & 4.150357 & -3.225239 & 1.029834 \\
\hline $\mathrm{N}$ & 4.625117 & -1.464839 & 0.032199 \\
\hline$N$ & 2.92904 & -0.480428 & -1.228644 \\
\hline $\mathrm{H}$ & 6.600917 & -0.775904 & 0.2472 \\
\hline $\mathrm{H}$ & 4.715088 & -1.083915 & 2.625326 \\
\hline $\mathrm{H}$ & 5.386314 & 1.254483 & 3.122459 \\
\hline $\mathrm{H}$ & 4.453101 & 2.492714 & 1.222633 \\
\hline $\mathrm{H}$ & 5.633465 & 0.999004 & -0.574566 \\
\hline $\mathrm{H}$ & 4.491586 & -3.429864 & -0.693085 \\
\hline C & 2.502833 & -2.680091 & -0.25252 \\
\hline $\mathrm{H}$ & 2.082061 & -3.668838 & -0.438126 \\
\hline C & 2.287743 & -1.773272 & -1.453359 \\
\hline $\mathrm{H}$ & 2.699556 & -2.222579 & -2.364287 \\
\hline $\mathrm{H}$ & 1.22054 & -1.606231 & -1.588267 \\
\hline $\mathrm{H}$ & 1.960408 & -2.25549 & 0.594402 \\
\hline C & 0.233754 & 1.08772 & -0.948069 \\
\hline $\mathrm{H}$ & -0.10212 & 0.198834 & -1.499087 \\
\hline $\mathrm{H}$ & -0.492166 & 1.901006 & -1.088468 \\
\hline C & 0.31726 & 0.748253 & 0.537897 \\
\hline $\mathrm{H}$ & 1.113308 & 0.015579 & 0.695569 \\
\hline 0 & 1.473385 & 1.513757 & -1.441167 \\
\hline $\mathrm{H}$ & 2.287241 & 0.536541 & -1.411508 \\
\hline $\mathrm{O}$ & -0.912688 & 0.261721 & 1.040605 \\
\hline $\mathrm{H}$ & -2.248737 & 0.808844 & -1.393862 \\
\hline C & -1.215557 & -1.095671 & 0.780311 \\
\hline
\end{tabular}




$\begin{array}{rrrr}\mathrm{C} & 1.802656 & 3.275844 & -1.267954 \\ \mathrm{O} & -2.312887 & -1.429815 & 1.24692 \\ \mathrm{O} & -0.398971 & -1.732947 & 0.100054 \\ \mathrm{O} & 2.954461 & 3.39591 & -1.532914 \\ \mathrm{O} & 0.777736 & 3.774934 & -0.94126 \\ \mathrm{H} & 0.54816 & 1.660396 & 1.093749\end{array}$

\section{1,3-propanediol as substrate}

\section{TS ALKYLATION}

\begin{tabular}{|c|c|c|c|}
\hline 01 & $x$ & & Z \\
\hline C & -2.54722 & -3.465127 & -1.273719 \\
\hline C & -1.023686 & -3.3707 & -1.379176 \\
\hline C & -0.486416 & -1.928639 & -1.38996 \\
\hline C & -3.144041 & -2.862643 & -0.000718 \\
\hline C & -0.38421 & -1.355706 & -0.006558 \\
\hline C & -2.81679 & -1.381868 & 0.185226 \\
\hline $\mathrm{H}$ & -2.986321 & -2.95432 & -2.138305 \\
\hline $\mathrm{H}$ & -0.55076 & -3.931008 & -0.5653 \\
\hline $\mathrm{H}$ & 0.503015 & -1.86942 & -1.843063 \\
\hline $\mathrm{H}$ & -4.23156 & -2.963445 & -0.039561 \\
\hline $\mathrm{H}$ & -3.49543 & -0.898892 & 0.885548 \\
\hline C & -1.385939 & -0.687497 & 2.12103 \\
\hline $\mathrm{H}$ & -2.167506 & -1.211502 & 2.674332 \\
\hline $\mathrm{N}$ & -1.462671 & -1.16054 & 0.725058 \\
\hline $\mathrm{N}$ & 0.829905 & -1.126188 & 0.475905 \\
\hline $\mathrm{H}$ & -2.92497 & -0.826463 & -0.748988 \\
\hline $\mathrm{H}$ & -2.805504 & -3.415996 & 0.88242 \\
\hline $\mathrm{H}$ & -2.844372 & -4.514106 & -1.348266 \\
\hline $\mathrm{H}$ & -0.707779 & -3.847672 & -2.309175 \\
\hline $\mathrm{H}$ & -1.119648 & -1.274917 & -1.994284 \\
\hline $\mathrm{H}$ & -1.628506 & 0.379113 & 2.122344 \\
\hline C & -0.021621 & -0.97525 & 2.72438 \\
\hline $\mathrm{H}$ & 0.062774 & -0.461487 & 3.681932 \\
\hline C & 1.066238 & -0.502301 & 1.775081 \\
\hline $\mathrm{H}$ & 1.062051 & 0.586725 & 1.657972 \\
\hline $\mathrm{H}$ & 2.055012 & -0.807607 & 2.116698 \\
\hline $\mathrm{H}$ & 0.096538 & -2.047505 & 2.901638 \\
\hline C & 3.849702 & 0.280894 & -1.332413 \\
\hline $\mathrm{H}$ & 4.077968 & 1.334671 & -1.505519 \\
\hline 0 & 2.490714 & 0.02731 & -1.687138 \\
\hline $\mathrm{H}$ & 1.588291 & -1.143191 & -0.200152 \\
\hline C & 1.570481 & 1.015795 & -1.320401 \\
\hline 0 & 0.446325 & 0.804947 & -1.855489 \\
\hline 0 & 1.906346 & 1.881743 & -0.528411 \\
\hline
\end{tabular}




$\begin{array}{lrrr}\mathrm{C} & 4.143258 & -0.083953 & 0.114564 \\ \mathrm{C} & 5.613775 & 0.081397 & 0.471755 \\ \mathrm{H} & 3.86271 & -1.12719 & 0.304287 \\ \mathrm{H} & 3.539986 & 0.564954 & 0.755792 \\ \mathrm{H} & 6.227798 & -0.598528 & -0.122805 \\ \mathrm{H} & 5.941255 & 1.104382 & 0.246682 \\ \mathrm{H} & 4.443515 & -0.330616 & -2.01473 \\ \mathrm{O} & 5.86618 & -0.249297 & 1.825287 \\ \mathrm{H} & 5.445009 & 0.418877 & 2.370962 \\ \mathrm{C} & -1.022346 & 1.744117 & -0.890129 \\ \mathrm{C} & -0.883765 & 3.125617 & -1.455703 \\ \mathrm{H} & -1.653088 & 1.01816 & -1.370848 \\ \mathrm{H} & -0.516193 & 1.48484 & 0.023496 \\ \mathrm{H} & -1.822644 & 3.445173 & -1.903924 \\ \mathrm{H} & -0.605768 & 3.827398 & -0.672419 \\ \mathrm{H} & -0.102773 & 3.115998 & -2.216065 \\ \mathrm{Br} & -3.004423 & 2.155092 & 0.567686\end{array}$

\section{TS BISCARBONATION}

\begin{tabular}{|c|c|c|c|}
\hline 01 & $x$ & & Z \\
\hline C & 4.490922 & -2.074216 & 1.331298 \\
\hline C & 3.512593 & -0.924629 & 1.573395 \\
\hline C & 3.594576 & 0.216584 & 0.542402 \\
\hline C & 4.273414 & -2.820393 & 0.016395 \\
\hline C & 2.830198 & -0.055889 & -0.727286 \\
\hline C & 4.385177 & -1.906821 & -1.204854 \\
\hline $\mathrm{H}$ & 5.515431 & -1.682209 & 1.346711 \\
\hline $\mathrm{H}$ & 2.486914 & -1.30392 & 1.60929 \\
\hline $\mathrm{H}$ & 3.184355 & 1.13592 & 0.959927 \\
\hline $\mathrm{H}$ & 5.02013 & -3.614247 & -0.074175 \\
\hline $\mathrm{H}$ & 4.56304 & -2.497594 & -2.104617 \\
\hline C & 2.340666 & -1.602796 & -2.579702 \\
\hline $\mathrm{H}$ & 2.261295 & -2.689529 & -2.483212 \\
\hline $\mathrm{N}$ & 3.178797 & -1.122425 & -1.473016 \\
\hline $\mathrm{N}$ & 1.858522 & 0.743894 & -1.048569 \\
\hline $\mathrm{H}$ & 5.24398 & -1.237127 & -1.09986 \\
\hline $\mathrm{H}$ & 3.288302 & -3.299052 & 0.008 \\
\hline $\mathrm{H}$ & 4.415381 & -2.780495 & 2.161713 \\
\hline $\mathrm{H}$ & 3.725575 & -0.495772 & 2.5559 \\
\hline $\mathrm{H}$ & 4.64025 & 0.428086 & 0.293354 \\
\hline $\mathrm{H}$ & 2.850555 & -1.385899 & -3.52507 \\
\hline C & 0.966636 & -0.95742 & -2.54512 \\
\hline $\mathrm{H}$ & 0.456271 & -1.138595 & -3.492464 \\
\hline C & 1.136002 & 0.533576 & -2.300198 \\
\hline $\mathrm{H}$ & 1.693193 & 1.011572 & -3.112821 \\
\hline
\end{tabular}




\begin{tabular}{|c|c|c|c|}
\hline $\mathrm{H}$ & 0.187279 & 1.058025 & -2.228472 \\
\hline $\mathrm{H}$ & 0.354297 & -1.391341 & -1.749313 \\
\hline C & 0.728443 & 0.794553 & 2.49328 \\
\hline $\mathrm{H}$ & 0.923729 & 0.48704 & 1.468263 \\
\hline C & 0.752578 & 4.00457 & -0.968499 \\
\hline 0 & 0.642177 & 3.424527 & -2.003133 \\
\hline $\mathrm{O}$ & 0.779668 & 5.02789 & -0.375768 \\
\hline C & 0.311314 & 2.253006 & 2.51095 \\
\hline C & 1.200279 & 3.054092 & 1.562388 \\
\hline $\mathrm{H}$ & 0.354368 & 2.659547 & 3.524769 \\
\hline $\mathrm{H}$ & -0.719794 & 2.337783 & 2.1579 \\
\hline $\mathrm{H}$ & 0.988509 & 4.122017 & 1.655529 \\
\hline $\mathrm{H}$ & 2.259832 & 2.917351 & 1.834445 \\
\hline $\mathrm{H}$ & 1.634529 & 0.638578 & 3.086749 \\
\hline $\mathrm{O}$ & 0.968336 & 2.678826 & 0.227958 \\
\hline $\mathrm{H}$ & 1.502029 & 1.671284 & -0.364586 \\
\hline C & -3.480345 & 2.212756 & -0.762782 \\
\hline C & -2.21569 & 1.455364 & -1.164163 \\
\hline C & -1.752482 & 0.40402 & -0.143624 \\
\hline C & -4.724844 & 1.339838 & -0.621583 \\
\hline C & -2.443599 & -0.938019 & -0.24223 \\
\hline C & -4.546513 & 0.195967 & 0.376927 \\
\hline $\mathrm{H}$ & -3.291384 & 2.715241 & 0.193659 \\
\hline $\mathrm{H}$ & -2.356991 & 0.975091 & -2.139947 \\
\hline $\mathrm{H}$ & -0.685533 & 0.220527 & -0.268719 \\
\hline $\mathrm{H}$ & -5.562236 & 1.960648 & -0.28937 \\
\hline $\mathrm{H}$ & -5.523544 & -0.194166 & 0.666383 \\
\hline C & -4.548802 & -2.193702 & -0.27753 \\
\hline $\mathrm{H}$ & -5.481616 & -1.971704 & -0.804024 \\
\hline $\mathrm{N}$ & -3.797119 & -0.946771 & -0.150407 \\
\hline$N$ & -1.697787 & -1.986371 & -0.415469 \\
\hline $\mathrm{H}$ & -4.072944 & 0.553771 & 1.296944 \\
\hline $\mathrm{H}$ & -5.004807 & 0.912521 & -1.590659 \\
\hline $\mathrm{H}$ & -3.670325 & 3.002267 & -1.494273 \\
\hline $\mathrm{H}$ & -1.404682 & 2.178328 & -1.279178 \\
\hline $\mathrm{H}$ & -1.883209 & 0.79722 & 0.872294 \\
\hline $\mathrm{H}$ & -4.804738 & -2.567113 & 0.721463 \\
\hline C & -3.733799 & -3.226775 & -1.034437 \\
\hline $\mathrm{H}$ & -4.234164 & -4.195934 & -0.994579 \\
\hline C & -2.346671 & -3.291641 & -0.411035 \\
\hline $\mathrm{H}$ & -2.419362 & -3.642255 & 0.62668 \\
\hline $\mathrm{H}$ & -1.708949 & -3.992751 & -0.952953 \\
\hline $\mathrm{H}$ & -3.645962 & -2.931482 & -2.083831 \\
\hline $\mathrm{O}$ & -0.30834 & -0.028354 & 3.04585 \\
\hline $\mathrm{H}$ & -0.506469 & -1.864046 & 0.642088 \\
\hline C & -0.750146 & -1.094726 & 2.361228 \\
\hline
\end{tabular}




$\begin{array}{lrrr}0 & -1.818673 & -1.584318 & 2.611586 \\ 0 & 0.080724 & -1.517279 & 1.41238\end{array}$

\section{1,4-butanediol as substrate}

\begin{tabular}{|c|c|c|c|}
\hline 01 & $x$ & $\mathrm{Y}$ & Z \\
\hline C & -4.58571300 & -2.17616200 & -1.52771300 \\
\hline $\mathrm{C}$ & -3.21198100 & -2.59302500 & -1.00423400 \\
\hline $\mathrm{C}$ & -2.22412300 & -1.42871100 & -0.82044500 \\
\hline $\mathrm{C}$ & -5.36229800 & -1.25251100 & -0.59174600 \\
\hline $\mathrm{C}$ & -2.40092900 & -0.66653000 & 0.46144300 \\
\hline $\mathrm{C}$ & -4.62069700 & 0.04040900 & -0.25671500 \\
\hline $\mathrm{H}$ & -4.45348900 & -1.66976700 & -2.49080000 \\
\hline $\mathrm{H}$ & -3.31365000 & -3.13481600 & -0.05818200 \\
\hline $\mathrm{H}$ & -1.19975500 & -1.80330800 & -0.82616500 \\
\hline $\mathrm{H}$ & -6.31073300 & -0.98363500 & -1.06482000 \\
\hline $\mathrm{H}$ & -5.31741000 & 0.77352000 & 0.14956500 \\
\hline $\mathrm{C}$ & -3.73075100 & 0.69344400 & 1.97424400 \\
\hline $\mathrm{H}$ & -4.76020400 & 0.57753200 & 2.31862500 \\
\hline $\mathrm{N}$ & -3.57679600 & -0.12411600 & 0.76568500 \\
\hline $\mathrm{N}$ & -1.36718600 & -0.60246700 & 1.26718600 \\
\hline $\mathrm{H}$ & -4.17458500 & 0.49724000 & -1.14561000 \\
\hline $\mathrm{H}$ & -5.60531900 & -1.77054100 & 0.34199000 \\
\hline $\mathrm{H}$ & -5.18119500 & -3.07136700 & -1.72446900 \\
\hline $\mathrm{H}$ & -2.76376100 & -3.29168500 & -1.71351200 \\
\hline $\mathrm{H}$ & -2.31518000 & -0.70590800 & -1.64024100 \\
\hline $\mathrm{H}$ & -3.56321200 & 1.73953600 & 1.69530800 \\
\hline C & -2.75280400 & 0.25897100 & 3.05383800 \\
\hline $\mathrm{H}$ & -2.79938100 & 0.95800500 & 3.88929100 \\
\hline 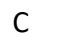 & -1.35213500 & 0.22447900 & 2.46423100 \\
\hline
\end{tabular}




\begin{tabular}{|c|c|c|c|}
\hline $\mathrm{H}$ & -1.03134600 & 1.23544400 & 2.18966700 \\
\hline $\mathrm{H}$ & -0.62955500 & -0.20299100 & 3.15892500 \\
\hline $\mathrm{H}$ & -3.02013500 & -0.73413400 & 3.42362300 \\
\hline C & 4.20654200 & -1.62565300 & -0.69044800 \\
\hline $\mathrm{H}$ & 4.04714100 & -1.03695300 & -1.59605200 \\
\hline $\mathrm{O}$ & 2.95360500 & -2.07676000 & -0.17877800 \\
\hline $\mathrm{H}$ & -0.46439800 & -1.01184900 & 0.92374200 \\
\hline C & 1.92378700 & -1.19539400 & -0.16234300 \\
\hline $\mathrm{O}$ & 0.85515100 & -1.64749100 & 0.28231100 \\
\hline $\mathrm{O}$ & 2.14501600 & -0.03456500 & -0.59961300 \\
\hline C & 4.98265100 & -0.81933500 & 0.33798100 \\
\hline C & 6.35911200 & -0.42193300 & -0.18663300 \\
\hline $\mathrm{H}$ & 5.08216500 & -1.42021700 & 1.24797400 \\
\hline $\mathrm{H}$ & 4.40159200 & 0.07217900 & 0.58861300 \\
\hline C & 7.15055000 & 0.38118000 & 0.82618600 \\
\hline $\mathrm{H}$ & 6.94151100 & -1.31099000 & -0.44904600 \\
\hline $\mathrm{H}$ & 6.26111300 & 0.17707300 & -1.09732000 \\
\hline $\mathrm{H}$ & 6.59552000 & 1.29306400 & 1.08469600 \\
\hline $\mathrm{H}$ & 7.27745300 & -0.20867000 & 1.74426700 \\
\hline $\mathrm{H}$ & 4.74749600 & -2.53822000 & -0.94711100 \\
\hline C & 1.22158900 & 2.22081900 & -1.57818200 \\
\hline $\mathrm{H}$ & 2.25860800 & 1.91393300 & -1.71560200 \\
\hline $\mathrm{H}$ & 1.19252800 & 3.18288500 & -1.07043500 \\
\hline $\mathrm{H}$ & 0.74422700 & 2.32872100 & -2.55020200 \\
\hline C & 0.52148200 & 1.17594000 & -0.76303600 \\
\hline $\mathrm{H}$ & 0.52801900 & 1.21844400 & 0.31199700 \\
\hline $\mathrm{H}$ & 0.02969300 & 0.33926500 & -1.22816500 \\
\hline $\mathrm{Br}$ & -1.68918100 & 2.28798900 & -0.68785000 \\
\hline $\mathrm{O}$ & 8.40488600 & 0.69501800 & 0.24579400 \\
\hline $\mathrm{H}$ & 8.91048400 & 1.20913400 & 0.87782800 \\
\hline
\end{tabular}




\section{TS BISCARBONATION}

\begin{tabular}{|c|c|c|c|}
\hline 01 & $x$ & $Y$ & Z \\
\hline $\mathrm{C}$ & 7.06411800 & 1.05617700 & -1.74019600 \\
\hline C & 5.87277100 & 1.84333100 & -1.19916300 \\
\hline C & 4.62293400 & 0.98532400 & -0.95197000 \\
\hline C & 7.59333000 & -0.00136800 & -0.77579600 \\
\hline $\mathrm{C}$ & 4.61582900 & 0.23487000 & 0.34557200 \\
\hline $\mathrm{C}$ & 6.55048000 & -1.03584900 & -0.35991900 \\
\hline $\mathrm{H}$ & 6.76324400 & 0.56600200 & -2.67270900 \\
\hline $\mathrm{H}$ & 6.15223700 & 2.36791200 & -0.27923400 \\
\hline $\mathrm{H}$ & 3.72876200 & 1.60838400 & -0.97537300 \\
\hline $\mathrm{H}$ & 8.41832900 & -0.53620600 & -1.25429900 \\
\hline $\mathrm{H}$ & 7.05221600 & -1.90037300 & 0.07335100 \\
\hline $\mathrm{C}$ & 5.44481100 & -1.48622400 & 1.81280100 \\
\hline $\mathrm{H}$ & 6.43953600 & -1.75359000 & 2.17098000 \\
\hline$N$ & 5.61763000 & -0.56354800 & 0.68019900 \\
\hline $\mathrm{N}$ & 3.58994500 & 0.43816700 & 1.15767100 \\
\hline $\mathrm{H}$ & 5.95236600 & -1.40384900 & -1.19916900 \\
\hline $\mathrm{H}$ & 7.99938800 & 0.47262300 & 0.12396400 \\
\hline $\mathrm{H}$ & 7.86996500 & 1.74998100 & -1.99337700 \\
\hline $\mathrm{H}$ & 5.60131300 & 2.61210800 & -1.92569800 \\
\hline $\mathrm{H}$ & 4.47415900 & 0.22784700 & -1.72966000 \\
\hline $\mathrm{H}$ & 4.93721300 & -2.37238200 & 1.41618000 \\
\hline $\mathrm{C}$ & 4.63090400 & -0.83996500 & 2.92000600 \\
\hline $\mathrm{H}$ & 4.45430500 & -1.56767000 & 3.71241100 \\
\hline $\mathrm{C}$ & 3.30640700 & -0.36899400 & 2.34707500 \\
\hline $\mathrm{H}$ & 2.67480400 & -1.21054700 & 2.04483600 \\
\hline $\mathrm{H}$ & 2.76681200 & 0.26118500 & 3.05480200 \\
\hline $\mathrm{H}$ & 5.18213800 & 0.00302000 & 3.34529200 \\
\hline C & 0.75789300 & -0.31003800 & -1.39971100 \\
\hline $\mathrm{H}$ & 0.13211300 & -1.19672200 & -1.26789900 \\
\hline
\end{tabular}




\begin{tabular}{|c|c|c|c|}
\hline $\mathrm{O}$ & 2.12002600 & -0.68491500 & -1.46009200 \\
\hline $\mathrm{H}$ & 2.82607200 & 0.97453200 & 0.77032900 \\
\hline C & 2.53254900 & -1.70057200 & -0.55536600 \\
\hline 0 & 3.72828100 & -1.99631500 & -0.70420900 \\
\hline 0 & 1.69497200 & -2.09114900 & 0.26227900 \\
\hline C & 0.46866500 & 0.67212100 & -0.27030500 \\
\hline C & -0.99939000 & 1.07615400 & -0.22955200 \\
\hline $\mathrm{H}$ & 1.08616800 & 1.57163100 & -0.40543400 \\
\hline $\mathrm{H}$ & 0.74297000 & 0.18350800 & 0.67108800 \\
\hline C & -1.33779400 & 2.00165000 & 0.93248500 \\
\hline $\mathrm{H}$ & -1.27712500 & 1.58588900 & -1.15982800 \\
\hline $\mathrm{H}$ & -1.61611300 & 0.17289300 & -0.14946900 \\
\hline $\mathrm{H}$ & -1.08906600 & 1.51855600 & 1.88594200 \\
\hline $\mathrm{H}$ & -0.76555700 & 2.92981200 & 0.85353600 \\
\hline $\mathrm{H}$ & 0.52594900 & 0.15301400 & -2.36318200 \\
\hline C & -4.58023900 & -1.82541000 & -2.71471400 \\
\hline C & -3.64647200 & -0.85456500 & -1.99024100 \\
\hline C & -4.36473700 & 0.29274100 & -1.25754600 \\
\hline C & -5.54758400 & -2.57878300 & -1.80132800 \\
\hline C & -4.85217400 & -0.11035900 & 0.10652400 \\
\hline C & -6.43936500 & -1.65163700 & -0.97322500 \\
\hline $\mathrm{H}$ & -5.16328000 & -1.26423100 & -3.45461000 \\
\hline $\mathrm{H}$ & -3.01630200 & -1.40194500 & -1.28068800 \\
\hline $\mathrm{H}$ & -3.70137400 & 1.14140900 & -1.11650300 \\
\hline $\mathrm{H}$ & -6.18968600 & -3.21894900 & -2.41287700 \\
\hline $\mathrm{H}$ & -7.30527100 & -2.19770400 & -0.59615600 \\
\hline C & -6.14069400 & -1.66883900 & 1.49969000 \\
\hline $\mathrm{H}$ & -6.23766900 & -2.74919700 & 1.36370900 \\
\hline $\mathrm{N}$ & -5.77276500 & -1.08897600 & 0.20421900 \\
\hline $\mathrm{N}$ & -4.32520000 & 0.46968000 & 1.14233600 \\
\hline $\mathrm{H}$ & -6.82938600 & -0.84148800 & -1.59526200 \\
\hline
\end{tabular}




\begin{tabular}{|c|c|c|c|}
\hline $\mathrm{H}$ & -4.99682800 & -3.23586500 & -1.11923000 \\
\hline $\mathrm{H}$ & -3.98076100 & -2.54810100 & -3.27376000 \\
\hline $\mathrm{H}$ & -2.96681000 & -0.40896600 & -2.72042000 \\
\hline $\mathrm{H}$ & -5.20563400 & 0.66731300 & -1.84908900 \\
\hline $\mathrm{H}$ & -7.11892900 & -1.28028500 & 1.80430000 \\
\hline C & -5.08747400 & -1.35965400 & 2.55196800 \\
\hline $\mathrm{H}$ & -5.46005800 & -1.63885700 & 3.53820100 \\
\hline C & -4.75067600 & 0.12300000 & 2.48828900 \\
\hline $\mathrm{H}$ & -5.62100100 & 0.72916800 & 2.76237900 \\
\hline $\mathrm{H}$ & -3.94072500 & 0.38269000 & 3.17061300 \\
\hline $\mathrm{H}$ & -4.18368700 & -1.94079300 & 2.35150400 \\
\hline 0 & -2.70822200 & 2.33373500 & 0.94470500 \\
\hline $\mathrm{H}$ & -3.54587200 & 1.36910000 & 1.01629900 \\
\hline C & -3.19928900 & 3.50911200 & -0.12635500 \\
\hline 0 & -4.38325800 & 3.35811800 & -0.26722800 \\
\hline 0 & -2.25492700 & 4.15784300 & -0.47306700 \\
\hline
\end{tabular}

\section{1,5-pentanediol as substrate}

\section{TS ALKYLATION}

$\begin{array}{llll}\text { O 1 } & \mathrm{X} & \mathrm{Z} \\ \mathrm{C} & -5.085124 & -2.134001 & -1.262159 \\ \mathrm{C} & -3.709531 & -2.573967 & -0.762948 \\ \mathrm{C} & -2.667874 & -1.444367 & -0.69886 \\ \mathrm{C} & -5.784564 & -1.115602 & -0.364469 \\ \mathrm{C} & -2.761204 & -0.591072 & 0.53353 \\ \mathrm{C} & -4.977022 & 0.163001 & -0.148153 \\ \mathrm{H} & -4.971303 & -1.700801 & -2.262587 \\ \mathrm{H} & -3.79482 & -3.044603 & 0.221964 \\ \mathrm{H} & -1.660596 & -1.862304 & -0.718189 \\ \mathrm{H} & -6.739311 & -0.837932 & -0.819393 \\ \mathrm{H} & -5.625467 & 0.952128 & 0.232228 \\ \mathrm{C} & -3.972015 & 0.923676 & 1.998362 \\ \mathrm{H} & -4.991157 & 0.87707 & 2.38684 \\ \mathrm{~N} & -3.900196 & 0.021945 & 0.843192 \\ \mathrm{~N} & -1.694652 & -0.519821 & 1.294946 \\ \mathrm{H} & -4.548946 & 0.538367 & -1.082812\end{array}$




\begin{tabular}{|c|c|c|c|}
\hline $\mathrm{H}$ & -6.011022 & -1.557714 & 0.611497 \\
\hline $\mathrm{H}$ & -5.724259 & -3.013677 & -1.373345 \\
\hline $\mathrm{H}$ & -3.319979 & -3.338737 & -1.437833 \\
\hline $\mathrm{H}$ & -2.763406 & -0.775243 & -1.562484 \\
\hline $\mathrm{H}$ & -3.77121 & 1.940331 & 1.643042 \\
\hline C & -2.971856 & 0.517955 & 3.068763 \\
\hline $\mathrm{H}$ & -2.956026 & 1.271895 & 3.856223 \\
\hline C & -1.597956 & 0.382236 & 2.432574 \\
\hline $\mathrm{H}$ & -1.24591 & 1.357876 & 2.079666 \\
\hline $\mathrm{H}$ & -0.867539 & -0.030666 & 3.127867 \\
\hline $\mathrm{H}$ & -3.266276 & -0.435603 & 3.514285 \\
\hline C & 3.769637 & -1.88155 & -0.750687 \\
\hline $\mathrm{H}$ & 3.613243 & -1.333546 & -1.682234 \\
\hline $\mathrm{O}$ & 2.511489 & -2.256473 & -0.192914 \\
\hline $\mathrm{H}$ & -0.824596 & -0.9895 & 0.946454 \\
\hline C & 1.516434 & -1.335573 & -0.203798 \\
\hline $\mathrm{O}$ & 0.442968 & -1.718776 & 0.29015 \\
\hline $\mathrm{O}$ & 1.770941 & -0.211038 & -0.712753 \\
\hline C & 4.597512 & -1.056102 & 0.220574 \\
\hline C & 5.972616 & -0.721116 & -0.351503 \\
\hline $\mathrm{H}$ & 4.706606 & -1.617023 & 1.154326 \\
\hline $\mathrm{H}$ & 4.053468 & -0.135323 & 0.446815 \\
\hline C & 6.831202 & 0.09034 & 0.615089 \\
\hline $\mathrm{H}$ & 6.49908 & -1.648051 & -0.609313 \\
\hline $\mathrm{H}$ & 5.850486 & -0.162905 & -1.287413 \\
\hline C & 8.194504 & 0.441189 & 0.037371 \\
\hline $\mathrm{H}$ & 6.303835 & 1.016217 & 0.878153 \\
\hline $\mathrm{H}$ & 6.981168 & -0.464711 & 1.546286 \\
\hline $\mathrm{H}$ & 8.740167 & -0.471833 & -0.211506 \\
\hline $\mathrm{H}$ & 8.06943 & 1.012889 & -0.892642 \\
\hline $\mathrm{H}$ & 4.269061 & -2.826858 & -0.971339 \\
\hline $\mathrm{O}$ & 9.011494 & 1.140854 & 0.958053 \\
\hline $\mathrm{H}$ & 8.55285 & 1.949655 & 1.197002 \\
\hline C & 0.899475 & 2.008577 & -1.8121 \\
\hline $\mathrm{H}$ & 1.919035 & 1.652822 & -1.96168 \\
\hline $\mathrm{H}$ & 0.923402 & 3.002432 & -1.369486 \\
\hline $\mathrm{H}$ & 0.393061 & 2.070971 & -2.773347 \\
\hline C & 0.189712 & 1.047863 & -0.90655 \\
\hline $\mathrm{H}$ & 0.234395 & 1.1615 & 0.162351 \\
\hline $\mathrm{H}$ & -0.350065 & 0.203225 & -1.298211 \\
\hline $\mathrm{Br}$ & -1.973494 & 2.250266 & -0.836248 \\
\hline
\end{tabular}




\begin{tabular}{|c|c|c|c|}
\hline 01 & $x$ & $Y$ & Z \\
\hline C & -7.496279 & -0.475588 & 2.481507 \\
\hline C & -5.976871 & -0.479424 & 2.633625 \\
\hline C & -5.220532 & -0.639482 & 1.306433 \\
\hline C & -8.031134 & 0.702109 & 1.672015 \\
\hline C & -5.058029 & 0.621541 & 0.512425 \\
\hline C & -7.458521 & 0.791626 & 0.259718 \\
\hline H & -7.799708 & -1.408031 & 1.992803 \\
\hline $\mathrm{H}$ & -5.645683 & 0.431549 & 3.143593 \\
\hline H & -4.224003 & -1.041743 & 1.489521 \\
\hline $\mathrm{H}$ & -9.117009 & 0.607889 & 1.584299 \\
\hline $\mathrm{H}$ & -8.082813 & 1.451629 & -0.341573 \\
\hline C & -5.938996 & 2.431194 & -0.809854 \\
\hline H & -6.741806 & 3.153411 & -0.657579 \\
\hline$N$ & -6.103481 & 1.371157 & 0.196808 \\
\hline $\mathrm{N}$ & -3.826034 & 0.9744 & 0.180559 \\
\hline $\mathrm{H}$ & -7.429676 & -0.173631 & -0.255314 \\
\hline $\mathrm{H}$ & -7.833317 & 1.64423 & 2.193999 \\
\hline H & -7.957946 & -0.47288 & 3.472394 \\
\hline $\mathrm{H}$ & -5.690897 & -1.316397 & 3.274229 \\
\hline H & -5.706401 & -1.351926 & 0.630255 \\
\hline $\mathrm{H}$ & -6.046768 & 1.948996 & -1.787709 \\
\hline C & -4.581957 & 3.099495 & -0.677364 \\
\hline $\mathrm{H}$ & -4.45706 & 3.828493 & -1.478421 \\
\hline C & -3.500289 & 2.038803 & -0.77235 \\
\hline $\mathrm{H}$ & -3.454789 & 1.595046 & -1.771954 \\
\hline H & -2.522847 & 2.438826 & -0.500921 \\
\hline H & -4.516512 & 3.625893 & 0.278746 \\
\hline C & 5.736753 & 3.353137 & 0.469447 \\
\hline C & 4.666358 & 2.271695 & 0.311318 \\
\hline C & 4.824504 & 1.402133 & -0.949634 \\
\hline C & 7.167819 & 2.829755 & 0.601623 \\
\hline C & 5.817144 & 0.287343 & -0.746241 \\
\hline C & 7.602668 & 1.971067 & -0.588741 \\
\hline H & 5.692313 & 4.025746 & -0.396471 \\
\hline $\mathrm{H}$ & 4.639911 & 1.611264 & 1.183297 \\
\hline $\mathrm{H}$ & 3.873915 & 0.928695 & -1.18936 \\
\hline $\mathrm{H}$ & 7.852304 & 3.678507 & 0.688098 \\
\hline $\mathrm{H}$ & 8.690721 & 1.900485 & -0.633459 \\
\hline C & 8.033902 & -0.395544 & 0.042663 \\
\hline $\mathrm{H}$ & 8.614298 & 0.105217 & 0.822249 \\
\hline$N$ & 7.108355 & 0.595597 & -0.521543 \\
\hline$N$ & 5.358277 & -0.928161 & -0.744699 \\
\hline
\end{tabular}




$\begin{array}{llll}\mathrm{H} & 7.282627 & 2.429951 & -1.52798 \\ \mathrm{H} & 7.271998 & 2.236472 & 1.516657 \\ \mathrm{H} & 5.498931 & 3.960754 & 1.346282 \\ \mathrm{H} & 3.689728 & 2.758207 & 0.256537 \\ \mathrm{H} & 5.115044 & 2.014169 & -1.809762 \\ \mathrm{H} & 8.730813 & -0.722638 & -0.737184 \\ \mathrm{C} & 7.270829 & -1.571926 & 0.626433 \\ \mathrm{H} & 7.966173 & -2.373498 & 0.878977 \\ \mathrm{C} & 6.239914 & -2.03345 & -0.394892 \\ \mathrm{H} & 6.730558 & -2.415214 & -1.297391 \\ \mathrm{H} & 5.617345 & -2.833927 & 0.008749 \\ \mathrm{H} & 6.738136 & -1.26241 & 1.528655 \\ \mathrm{C} & -2.809138 & -2.439547 & -1.473536 \\ \mathrm{H} & -2.601632 & -2.446865 & -2.546228 \\ \mathrm{O} & -4.113545 & -1.944716 & -1.235068\end{array}$

\section{References}

${ }^{1}$ T.M. McGuire, E.M. López-Vidal, G.L. Gregory, A. Buchard, J. CO2 Util., 27 (2018) 283-288. 